\title{
\#USGS
}

science for a changing world

\section{National Assessment of Shoreline Change: Historical Shoreline Change along the New England and Mid-Atlantic Coasts}

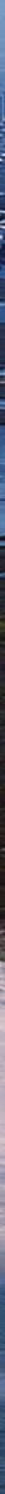


COVER:

The cover is an oblique aerial photograph of Brigantine Inlet, looking south toward Atlantic City, NJ. 


\section{National Assessment of Shoreline Change: Historical Shoreline Change along the New England and Mid-Atlantic Coasts}

by Cheryl J. Hapke, Emily A. Himmelstoss, Meredith G. Kratzmann, Jeffrey H. List, and E. Robert Thieler

Open-File Report 2010-1118 


\section{U.S. Department of the Interior \\ KEN SALAZAR, Secretary \\ U.S. Geological Survey \\ Marcia K. McNutt, Director}

\section{U.S. Geological Survey, Reston, Virginia: 2011}

This report and any updates to it are available online at: http://pubs.usgs.gov/of/2010/1118/

For product and ordering information: World Wide Web: http://www.usgs.gov/pubprod

Telephone: 1-888-ASK-USGS (1-888-275-8747)

For more information on the USGS - the Federal source for science about the Earth, its natural and living resources, natural hazards, and the environment:

World Wide Web: http://www.usgs.gov

Telephone: 1-888-ASK-USGS

Any use of trade, product, or firm names is for descriptive purposes only and does not imply endorsement by the U.S. Government.

Although this report is in the public domain, permission must be secured from the individual copyright owners to reproduce any copyrighted material contained within this report.

Suggested citation:

Hapke, C.J., Himmelstoss, E.A., Kratzmann, M.G., List, J.H., and Thieler, E.R., 2011, National assessment of shoreline change: Historical shoreline change along the New England and Mid-Atlantic coasts: U.S. Geological Survey OpenFile Report 2010-1118, 57p. 


\section{Contents}

Executive Summary

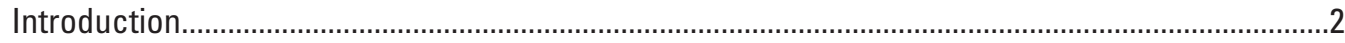

U.S. Geological Survey National Assessment of Shoreline Change Project...............................2

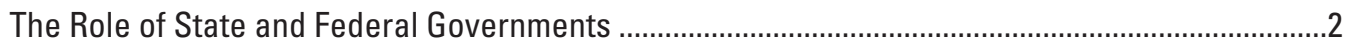

Prior New England And Mid-Atlantic Coast Shoreline Assessments ...............................................

Methods Of Analyzing Shoreline Change ......................................................................................

Compilation of Shoreline Position .............................................................................................

High Water Line (HWL) Shoreline .............................................................................

Lidar-Derived Mean High Water (MHW) Shoreline.........................................................

The Proxy-Datum Bias Correction between HWL and MHW Shorelines ...............................9

Uncertainty in the Proxy-Datum Bias ........................................................................

Use of the Proxy-Datum Bias and Bias Uncertainty in Shoreline Change Analysis ......11

Estimation of Shoreline Position Uncertainty ...................................................................11

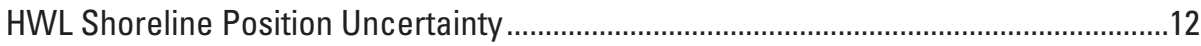

Lidar-Derived MHW Shoreline Position Uncertainty.....................................................12

Calculation and Interpretation of Shoreline Change Rates .................................................13

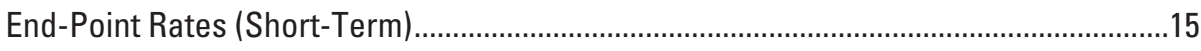

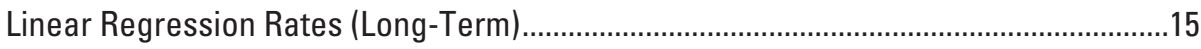

Estimation of Shoreline Change Rate Uncertainty ................................................................

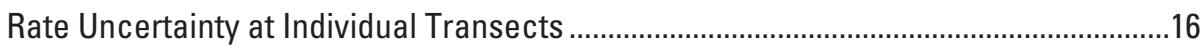

Regionally Averaged Rate Uncertainty ............................................................................16

Human Beach Alterations that Influence Rates of Change ....................................................17

Geology and Geomorphology of the New England and Mid-Atlantic Coast....................................17

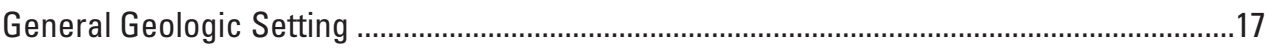

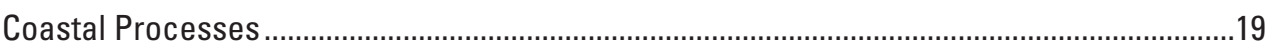

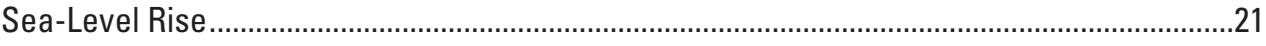

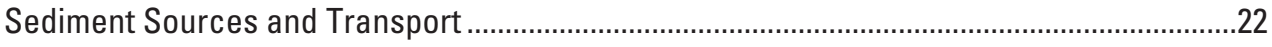

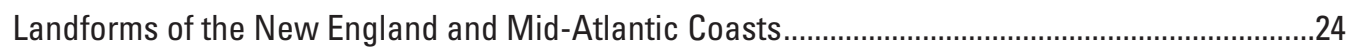

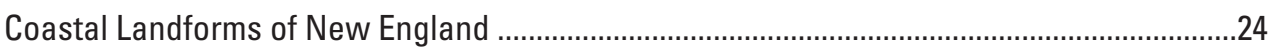

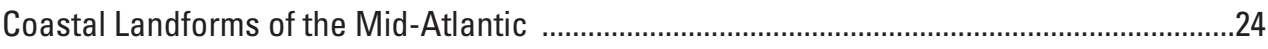

Estuaries and Lagoons in the New England and Mid-Atlantic Areas.....................................24

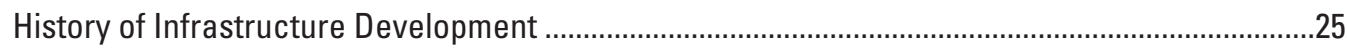

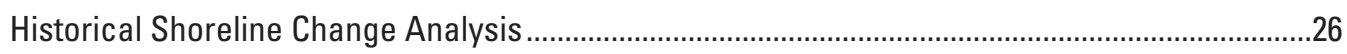

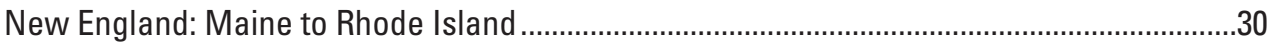

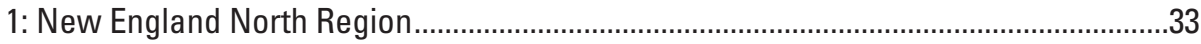

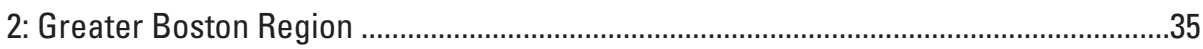

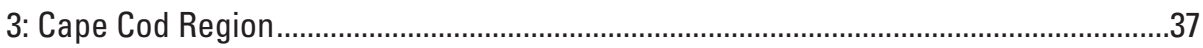

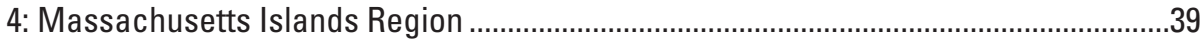

5: New England South Region ...............................................................................

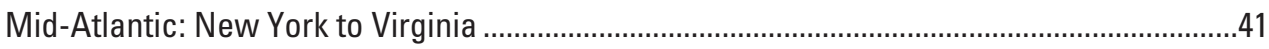

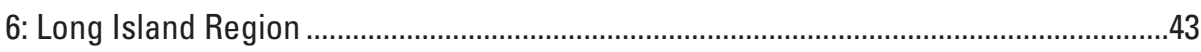




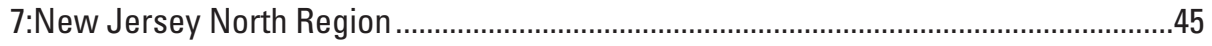

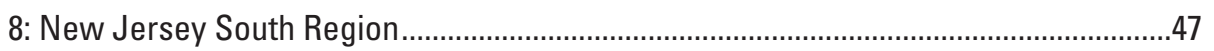

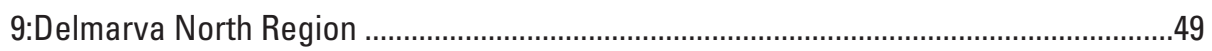

10: Delmarva South/Southern Virginia Region..................................................................51

Discussion and Additional Considerations...............................................................................52

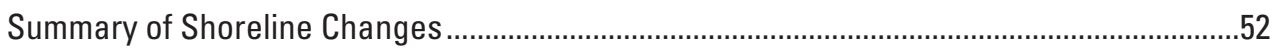

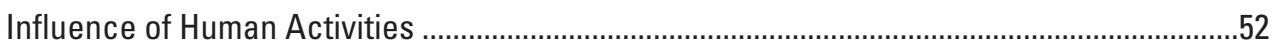

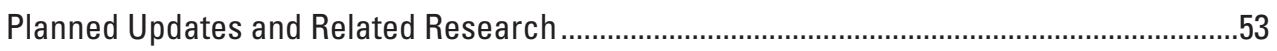

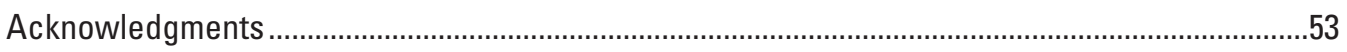

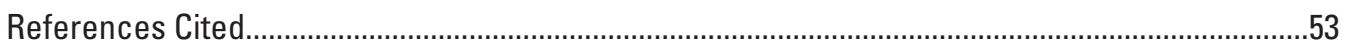

\section{Figures}

1. Index map of New England and the Mid-Atlantic showing the 10 analysis regions used

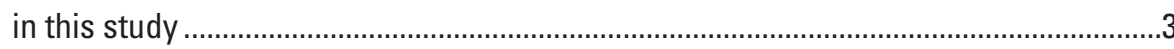

2. Graphs showing an example of a lidar profile from Island Beach State Park in New Jersey..

3. Schematic diagrams showing examples of common conditions where transects are eliminated in the absence of four shoreline intersections

4. Oblique aerial photograph showing an extensive groin field at Beach Haven, NJ.

5. Map of the (a) New England and (b) Mid-Atlantic coasts showing the geomorphic provinces and the general distribution of coastal landforms.

6. Map showing the Last Glacial Maximum extent of the Laurentide ice sheet in New England.....

7. Graphs showing sea-level rise curves for the last (a) 160,000 years and (b) 24,000 years on the East Coast of the United States.

8. Graphs showing long-term (100-year) trends in average annual sea level at selected tide gages in New England and the Mid-Atlantic

9. Oblique aerial photographs showing the various geomorphic shore types along the New England and Mid-Atlantic coasts .

10. Schematic diagram showing common coastal landforms of New England and the Mid-Atlantic

11. Index map of (a) New England and (b) the Mid-Atlantic showing geographic names discussed in this report.

12. Graphs showing long- and short-term shoreline change rates for the New England North region

13. Oblique aerial photograph of Castle Neck, MA, in the New England North region

14. Graphs showing long- and short-term shoreline change rates for the Greater Boston region.

15. Oblique aerial photographs of (a) Brace Cove, MA, looking west, with the city of Gloucester in the background; and (b) Duxbury Beach, MA, a popular tourist beach south of Boston, looking south, in the Greater Boston region .....

16. Graphs showing long- and short-term shoreline change rates for the Cape Cod region .

17. Oblique aerial photograph of Monomoy Island, MA...... 
18. Graphs showing long- and short-term shoreline change rates for the

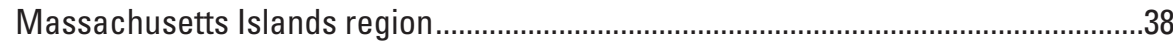

19. Oblique aerial photograph of Madaket Inlet and Esther Island in the Massachusetts

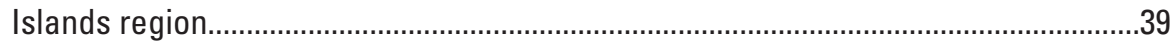

20. Graphs showing long- and short-term shoreline change rates for the New England South region.......................................................................................40

21. Oblique aerial photographs of locations in the New England South region....................41

22. Graphs showing long- and short-term shoreline change rates for the Long Island region....................................................................................................... 42

23. Oblique aerial photograph looking east along Jones Beach, NY ....................................43

24. Graphs showing long- and short-term shoreline change rates for the

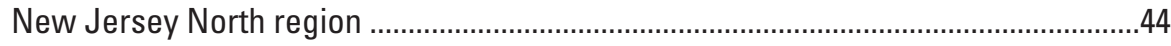

25. Oblique aerial photograph looking west along Long Branch, NJ.....................................45

26. Graphs showing long- and short-term shoreline change rates for the New Jersey South region ................................................................................................46

27. Oblique aerial photograph at Brigantine Inlet, looking south toward

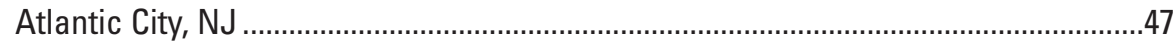

28. Graphs showing long- and short-term shoreline change rates for the Delmarva North region..............................................................................................48

29. Oblique aerial photograph of Ocean City Inlet in the Delmarva North region.................49

30. Graphs showing long- and short-term shoreline change rates for the Delmarva South/Southern Virginia region ...................................................................50

31. Oblique aerial photograph looking southwest along the southern end of Cedar Island in the Delmarva South/Southern Virginia region...

\section{Tables}

1. Providers and original sources of historical shorelines for each New England and Mid-Atlantic (NEMA) region.

2. Shorelines used to calculate short- and long-term change rates of the (a) New England region and (b) Mid-Atlantic region

3. List of tide-gage measurements used to calculate mean high water (MHW) elevation

4. Absolute horizontal and vertical differences between High Water Line (HWL) and Mean High Water Line (MHWL) shorelines..................................................................10

5. Average uncertainties for the New England and Mid-Atlantic shorelines ......................13

6. Long-term (a) and short-term (b) shoreline change rate uncertainties for New England and Mid-Atlantic regional averages.

7. Summary of major tropical and extratropical storms impacting the New England and Mid-Atlantic coasts since 1900

8. Relative distribution of geomorphic shore-types along the New England and Mid-Atlantic coasts .

9. Average long-term (a) and short-term (b) shoreline change rates for the New England and Mid-Atlantic (NEMA) coasts

10. Maximum shoreline change rates for the (a) New England and (b) Mid-Atlantic coast.. 


\section{Executive Summary}

Beach erosion is a chronic problem along many openocean shores of the United States. As coastal populations continue to grow and community infrastructures are threatened by erosion, there is increased demand for accurate information regarding past and present trends and rates of shoreline movement. There is also a need for a comprehensive analysis of shoreline movement that is consistent from one coastal region to another. To meet these national needs, the U.S. Geological Survey (USGS) is conducting an analysis of historical shoreline changes along open-ocean sandy shores of the conterminous United States and parts of Hawaii, Alaska, and the Great Lakes. One purpose of this work is to develop standard, repeatable methods for mapping and analyzing shoreline movement so that periodic, systematic, internally consistent updates regarding coastal erosion and land loss can be made nationally. In the case of this study, the shoreline is the interpreted boundary between the ocean water surface and the sandy beach.

This report on the New England and Mid-Atlantic coasts is the fifth in a series of reports on historical shoreline change. Previous investigations include analyses and descriptive reports of the Gulf of Mexico (Morton and others, 2004), the Southeast Atlantic (Morton and Miller, 2005), and, for California, the sandy shoreline (Hapke and others, 2006) and the coastal cliffs (Hapke and Reid, 2007). This report, like the earlier reports, summarizes the methods of analysis, interprets the results, provides explanations regarding long-term and short-term trends and rates of change, and describes how different coastal communities are responding to coastal erosion. This report differs from the earlier USGS reports in the series in that the previous shoreline change analyses incorporated only four total shorelines to represent specific time periods. The New England and Mid-Atlantic assessment incorporates all shorelines that are available and can be quality-checked. Shoreline change evaluations are based on a comparison of historical shoreline positions digitized from maps or aerial photographic data sources with recent shorelines, at least one of which is derived from lidar (light detection and ranging) surveys. The historical shorelines cover a variety of time periods ranging from the 1800 s through the 2000 s, whereas the lidar shoreline is from either 1997 or 2000. Long-term rates of change are calculated using all shorelines and short-term rates of change are calculated using the lidar shoreline and the historical shoreline that will produce an assessment for a 25to 30 -year time period. The rates of change presented in this report represent conditions up to the date of the most recent shoreline data and therefore are not intended for predicting future shoreline positions or rates of change. Because of the geomorphology of the New England and Mid-Atlantic (rocky coastlines, large embayments and beaches) as well as data gaps in some areas, this report presents beach erosion rates for 78 percent of the 1,360 kilometers of the New England and Mid-Atlantic coasts.

The New England and Mid-Atlantic shores were subdivided into a total of 10 analysis regions for the purpose of reporting regional trends in shoreline change rates. The average rate of long-term shoreline change for the New England and Mid-Atlantic coasts was -0.5 meters per year with an uncertainty in the long-term trend of \pm 0.09 meters per year. The rate is based on shoreline change rates averaged from 21,184 individual transects, of which 65 percent were eroding. In both the long and short term, the average rates of shoreline change for New England and the Mid-Atlantic were erosional. Long-term erosion rates were generally lower in New England than in the Mid-Atlantic. This is a function of the dominant coastal geomorphology; New England has a greater percentage of shore types that tend to erode more slowly (rocky coasts, pocket beaches, and mainland beaches), whereas the Mid-Atlantic is dominated by more vulnerable barrier islands and dynamic spit/inlet environments. However, the percentage of coastline eroding was higher in New England than in the Mid-Atlantic, highlighting that although rates of shoreline erosion may not be extreme, coastal erosion is still widespread along this region of the U.S. coastline.

The average rate of short-term shoreline change for the New England and Mid-Atlantic coasts was also erosional but the rate of erosion decreased in comparison to long-term rates. The net short-term rate as averaged along 17,045 transects was -0.3 meters per year. Uncertainties for these rates range from 0.06 to 0.1 meters per year depending on the data sources used in the rate calculations. Of transects used to measure short-term change, 60 percent were erosional, as compared to 65 percent of coast eroding in the long term. The slight decrease (5 percent) in the amount of coastline eroding may be related to an increase in the frequency and extent of nourishment programs and (or) the effects of hardened structures during the more recent time period. The most stable (lower rates of erosion) beaches were more commonly found in New England. Despite an overall lowering of the average rates of erosion from longterm to short-term, the amount of coastline undergoing more extreme erosion (rates greater than -1.0 meters per year) experienced widespread increase.

Coastal engineering structures that exist all along the New England and Mid-Atlantic coasts affect the rates of shoreline change, which vary substantially along the coast. However, it is difficult to isolate the influence of structures and nourishment projects on the regional long- and short-term rates, and such an endeavor is beyond the scope of this report. 


\section{Introduction}

\section{U.S. Geological Survey National Assessment of Shoreline Change Project}

Sandy ocean beaches are some of the most popular tourist and recreational destinations in the United States, and constitute some of the most valuable real estate in the country. These dynamic interfaces between water and land are commonly the sites of high-density residential and commercial development, despite the frequent natural hazards that can occur, including flooding, storm impacts, coastal erosion, and tsunami inundation. Partly in response to growing coastal hazards, the U.S. Geological Survey (USGS) is currently conducting a nationwide assessment of shoreline change rates and trends for openocean coasts. Shoreline position is one of the most commonly monitored indicators of environmental change (Morton, 1996), and is an easily understood feature representing the historical movement of beaches.

A principal purpose of the USGS shoreline change research is to develop a consistent methodology that allows for periodic updates that incorporate improved methods and data, yet still results in a dataset that is internally consistent at a national scale. In particular, recent methods for developing datum-based shorelines using lidar (light detection and ranging) data and assessing coastal change will provide the opportunity to achieve and incorporate more comprehensive error assessments in the future. The primary objectives of this effort are to conduct research on improved methods of assessing and monitoring shoreline movement and develop a better understanding of the processes controlling shoreline change. Achieving these objectives requires research that (1) examines the original sources of shoreline data (maps, air photos, lidar), (2) evaluates the errors associated with each data source, (3) investigates new methods for developing datum-based shorelines and quantifying potential bias and errors associated with integrating shoreline proxies from different sources, (4) develops standard, uniform methods of shoreline change analysis, (5) assesses the effects of human activities on shoreline movement and rates of change, and (6) integrates shoreline change observations with other information, such as geologic framework and sediment transport data.

This report summarizes historical changes (accretion and erosion) of sandy shorelines in 10 regions of the U.S. New England and Mid-Atlantic coasts (fig. 1). The report emphasizes the hazard from erosion at regional scales and strives to relate this hazard to the body of knowledge regarding coastal geology of the New England and Mid-Atlantic region because of its potential impact on natural resources and the economy. Results of the National Assessment of Shoreline Change are organized by coastal regions (Morton and others, 2004; Morton and Miller, 2005; Hapke and others, 2006; and Hapke and Reid, 2007). This report for the New England and Mid-Atlantic coasts is part of a series of reports that include text summarizing methods, results, and implications of the results. In addition, the geographic information system (GIS) data used in the analyses are made available for download. The rates of shoreline change are being published for the purpose of regional characterization. The shoreline change results and products presented in this report are not intended for detailed site-specific analysis of shoreline movement, nor are they intended to replace any official sources of shoreline change information identified by local or State government agencies, or other Federal entities that are used for regulatory purposes.

Rates of shoreline change presented herein may differ from other published rates, and differences do not necessarily indicate that the other rates are inaccurate. Some discrepancies are to be expected, considering the many possible ways of determining shoreline positions and rates of change, and the inherent uncertainty in calculating these rates. Rates of shoreline change presented in this report represent shoreline movement under past conditions and are not intended for use in predicting future shoreline positions or future rates of shoreline change.

\section{The Role of State and Federal Governments}

One reason for conducting this National Assessment of Shoreline Change is that there had been no widely accepted standardized method of analyzing shoreline changes. Each state or region has its own data needs and coastal-zone management responsibilities (for example, construction set-back lines). Therefore, different techniques and standards are used to compile shorelines and to calculate rates of shoreline movement. Consequently, existing calculated rates of shoreline change and projected shoreline positions are inconsistent from state to state and even within states, and cannot be compared directly or used to understand regional trends. These inconsistencies were clearly demonstrated by the Federal Emergency Management Agency- (FEMA) sponsored erosion studies (Crowell and Leatherman, 1999) that were used as the basis for evaluating erosion hazards (Heinz Center, 2000). The USGS National Assessment of Shoreline Change represents the first effort to compile shorelines from original data sources and calculate rates of shoreline change on a national scale using internally consistent methods. The results of the analyses allow direct comparison of rates of change from one coastal segment to another and form the basis for future comparison of shoreline position.

Several Federal agencies (USGS, FEMA, the National Oceanic and Atmospheric Administration (NOAA), U.S. Army Corps of Engineers (USACE)) have regulatory or 


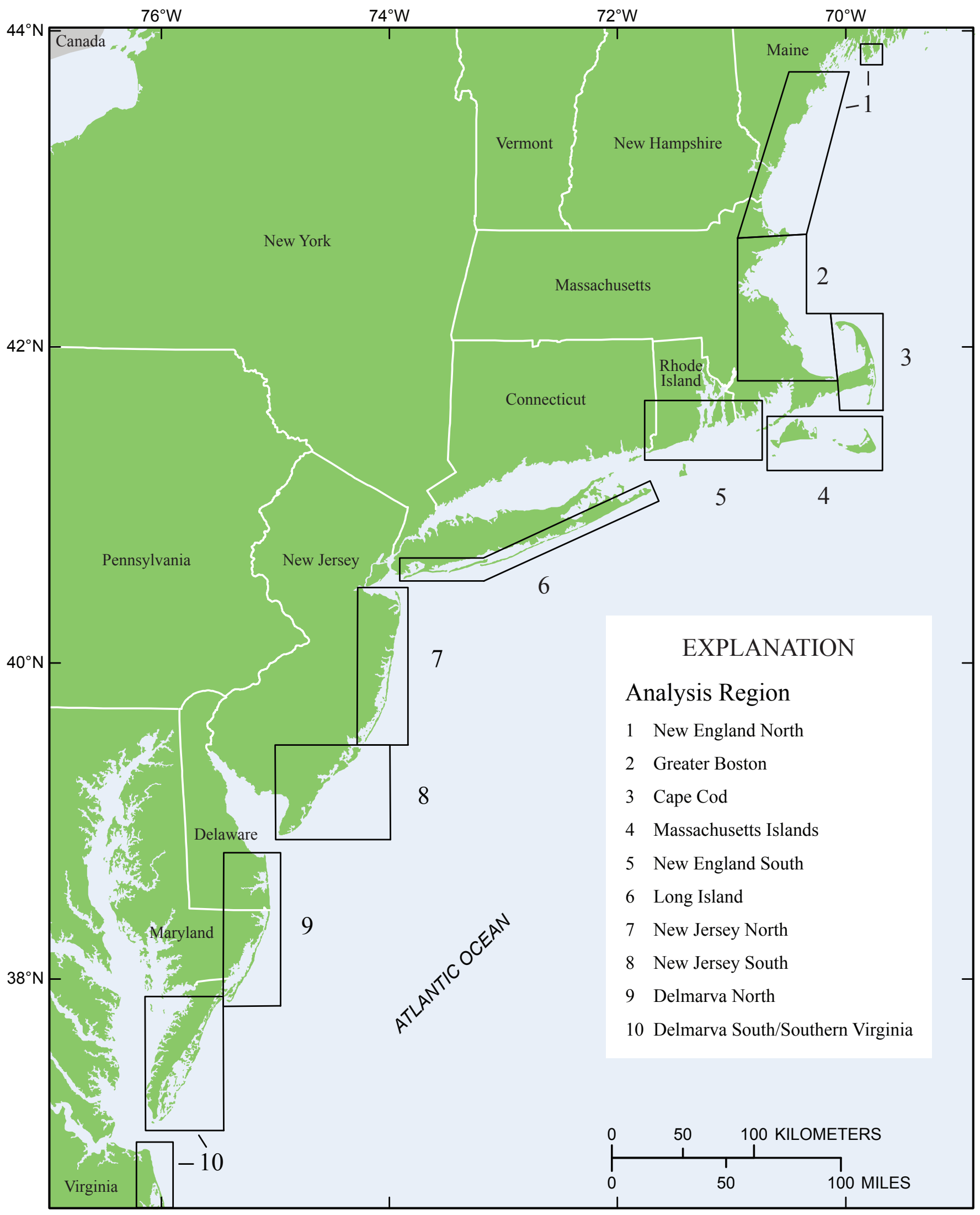

Figure 1. Index map of New England and the Mid-Atlantic showing the 10 analysis regions used in this study. 
administrative responsibilities pertaining to shorelines, yet these responsibilities are quite different, requiring different approaches and offering substantial opportunities for cooperation. For example, the USACE is authorized and funded by Congress to report on the economic and environmental implications of shoreline change and the costs of erosion mitigation. The National Shoreline Management Study (Stauble and Brumbaugh, 2003) is being conducted by the USACE using existing shoreline data. The USGS will share data and information, such as the lidar-derived shoreline and rates of change, in support of their effort. NOAA has the mandate to establish the official shoreline boundary for the Nation using tidal datums. Because its emphasis is on safe navigation, NOAA is using the shoreline to generate nautical charts. FEMA is authorized and partially funded by Congress to map coastal (and riverine) flood-hazard areas. These maps and associated information are used for flood-risk assessment, flood-plain management, and setting insurance rates through the National Flood Insurance Program (NFIP). As a result of discrepancies that were identified in the way the NFIP assesses coastal erosion, Congress authorized FEMA to report on the economic impact of erosion hazards on coastal communities, and on the NFIP. To accomplish this, FEMA contracted with State agencies and academic researchers to conduct a pilot study of erosion hazards that included shoreline change data for limited geographic areas. The USGS is responsible for conducting research pertaining to coastal change hazards including shoreline change, understanding the processes that cause coastal change, and developing models to predict future change. The USGS is the only government agency that has a dedicated program to monitor coastal change into the future using consistent methods nationwide. Such a program is critically important for addressing national issues, such as identifying regions of chronic erosion due to storms, sediment deficits, and sea-level rise.

\section{Prior New England and Mid-Atlantic Coast Shoreline Assessments}

Few studies of regional shorelines change exist for the New England and Mid-Atlantic coast. The USACE (1971) conducted the first national assessment of coastal erosion that included New England and the Mid-Atlantic. The 1971 study identified areas of critical and non-critical erosion on the basis of economic development and potential for property loss, but rates of shoreline movement were not quantified. An abundance of analyses of shoreline change at specific sites has been conducted by private consultants or contractors, or cities and counties where data on erosion rates have been required for regulatory or management purposes. Some of these analyses were incorporated into regional shoreline change assessments by Dolan and others (1985), who presented rates of change on maps and summarized trends. This effort was expanded with the compilation of data in the Coastal Erosion Information System (Dolan and others, 1989), which was the first digital database that provided shoreline change information from different sources to make them available to end-users. The rates of change incorporated into the Coastal Erosion Information System were determined by using a variety of methods, techniques, and original data sources and, therefore, there was little consistency for comparison of rates or trends in a regional context.

Since the publication of these earlier works, methods of obtaining, analyzing, displaying, and storing shoreline data have improved substantially. Coastal scientists have not agreed on standard methods for analyzing and reporting shoreline changes, nor have they identified rigorous mathematical tests that are widely accepted for quantifying the change and associated errors, although many are based on the research presented in Dolan and others (1991). The FEMA-sponsored erosion study (Crowell and Leatherman, 1999) highlighted the variety of approaches being utilized for measuring shoreline change in different parts of the country. For the New England and Mid-Atlantic coast, researchers presented shoreline change analyses for one county each in Massachusetts (O'Connell and Leatherman, 1999), New York (Leatherman and Anders, 1999), and New Jersey (Farrell and others, 1999); the State of Delaware (Leatherman and Eskandary, 1999); and the City of Virginia Beach (Fenster and Dolan, 1999). Despite the more recent efforts using modern digital techniques for measuring coastal change, there is still a critical need for (1) a nationwide compilation of reliable shoreline data, including the most recent shoreline position; and (2) a standardization of methods for obtaining and comparing shoreline positions and mathematically analyzing the trends.

\section{Methods of Analyzing Shoreline Change}

Compilation of Shoreline Position

High Water Line (HWL) Shoreline

Coastal researchers in universities and government agencies in the United States have been quantifying rates of shoreline movement and studying coastal change for decades. Before global positioning system (GPS) and lidar technologies were developed, the most commonly used sources of historical shoreline position were NOAA T-sheets (Shalowitz, 1964) and aerial photographs. Extraction of shoreline position from these data sources involves georeferencing maps or aerial photographs, and subsequently interpreting and digitizing a shoreline position. Depending on location, data source, and scientific preference, different 
Table 1. Providers and original sources of historical shorelines for each New England and Mid-Atlantic (NEMA) region.

\begin{tabular}{|c|c|c|}
\hline Organization & Original Data Source & Spatial Coverage \\
\hline $\begin{array}{l}\text { National Oceanic and Atmospheric Administra- } \\
\text { tion (NOAA), Coastal Services Center }\end{array}$ & Scanned NOAA T-sheets & All NEMA regions \\
\hline U.S. Geological Survey & \begin{tabular}{|l|} 
Lidar data cooperative with NOAA and U.S. Army \\
Corps of Engineers
\end{tabular} & All NEMA regions \\
\hline $\begin{array}{l}\text { VA Coast Reserve Long-Term Ecological Re- } \\
\text { search (LTER) Project }\end{array}$ & $\begin{array}{l}\text { Digitized shorelines from NOAA T-sheets and } \\
1967 \text { air photos }\end{array}$ & Delmarva South \\
\hline MD Department of Natural Resources & Digitized shorelines from NOAA T-sheets & Delmarva North \\
\hline NY State Department of State & $\begin{array}{l}\text { Digitized shorelines from NOAA T-sheets, and } \\
\text { 1960-80s air photos }\end{array}$ & Long Island \\
\hline RI Geological Survey / Univ. of Rhode Island & Digitized shorelines from air photos & New England South \\
\hline MA Coastal Zone Management (CZM) & $\begin{array}{l}\text { Digitized shorelines from NOAA T-sheets and } \\
\text { 1970-90s air photos }\end{array}$ & All New England regions \\
\hline
\end{tabular}

proxies for shoreline position are used to document coastal change, including high water line (HWL), wet-dry line, vegetation line, dune toe or crest, toe or berm of the beach, cliff base or top, and the line of mean high water (MHW).

The USGS National Assessment of Shoreline Change analysis for the New England and Mid-Atlantic coast incorporates shoreline positions from a variety of dates and data sources. The earliest shoreline data are derived from T-sheets dating back to the mid-1800s. Several organizations have provided the USGS with digital maps and (or) shoreline data (table 1). In addition to shorelines from other organizations, shorelines were digitized from many historical T-sheets that were georeferenced in-house.

NOAA T-sheet indexes were used to determine T-sheet availability for shorelines that were not already available for download as Environmental Systems Research Institute (ESRI) GIS shapefiles. T-sheets were then requested from NOAA and received as scanned TIFF images. Existing digital shorelines from other data sources were compiled and a quality assessment was performed.

T-sheets were rectified using ERDAS IMAGINE geographic imaging software by placing at least six well-spaced ground control points (GCPs) on selected T-sheet graticules in geographic coordinates. Some T-sheets produced before 1930 required additional coordinate transformation information from NOAA to convert from the United States Standard Datum (USSD) to the North American Datum of 1927 (NAD 27). The datum transformation was applied to T-sheet graticule coordinates prior to rectification. Total root mean square error (RMSE) for the rectification process was maintained below 1 pixel, which is approximately $4 \mathrm{~m}$ at a scale of 1:20,000 and approximately $1.5 \mathrm{~m}$ at a scale of $1: 10,000$. Typically the resulting RMSE was much lower than 1 pixel. Newly georeferenced T-sheets were loaded in ArcGIS and shorelines were digitized. All shoreline vectors were converted to the Universal Transverse Mercator (UTM) projection on the North American Datum of 1983 (NAD 83).

Although the most recent shoreline used in the analysis is generally a mean high water (MHW) contour derived from lidar data (see next section), in several regions there are shorelines from aerial photography that are more recent than the lidar shorelines. Tables $2 a$ and $b$ list the final range of years for shorelines compiled for each period by region. Additional details on the years (and months, where known) of specific shorelines and their spatial coverage are available in the companion online data report (Himmelstoss and others, 2010). 
Table 2a. Shorelines used to calculate short- and long-term change rates of the New England region.

[HWL, high water line; MHW, mean high water; Lidar, light detection and ranging]

\begin{tabular}{|c|c|c|c|c|c|c|}
\hline \multirow[b]{2}{*}{ Region } & \multicolumn{3}{|c|}{$\begin{array}{l}\text { Short-Term Rate } \\
\text { (End Point) }\end{array}$} & \multicolumn{3}{|c|}{$\begin{array}{c}\text { Long-Term Rate } \\
\text { (Linear Regression) }\end{array}$} \\
\hline & Date $^{1}$ & Source & Type & Date $^{1}$ & Source & Type \\
\hline \multirow[t]{4}{*}{ New England North } & $1978 / 1979$ & Air photo & HWL & $1850-1871$ & T-sheet & HWL \\
\hline & 2000 & Lidar & MHW & 1901-1955 & T-sheet & HWL \\
\hline & & & & 1978-1979 & Air photo & HWL \\
\hline & & & & 2000 & Lidar & MHW \\
\hline \multirow[t]{5}{*}{ Greater Boston } & 1978 & Air photo & HWL & $1847-1895$ & T-sheet & HWL \\
\hline & 2000 & Lidar & MHW & $1909-1960$ & T-sheet & HWL \\
\hline & & & & 1978 & Air photo & HWL \\
\hline & & & & 1994 & Air photo & HWL \\
\hline & & & & 2000 & Lidar & MHW \\
\hline \multirow[t]{4}{*}{ Cape Cod } & 1970/1978 & Air photo & HWL & $1848-1886$ & T-sheet & HWL \\
\hline & 2000 & Lidar & MHW & 1909-1954 & T-sheet & $\mathrm{HWL}$ \\
\hline & & & & 1978-1979 & Air photo & HWL \\
\hline & & & & 1994 & Air photo & HWL \\
\hline \multirow[t]{4}{*}{ MA Islands } & 1970/1978 & Air photo & HWL & $1845-1897$ & T-sheet & HWL \\
\hline & 2000 & Lidar & MHW & 1978-1979 & Air photo & HWL \\
\hline & & & & 1994 & Air photo & HWL \\
\hline & & & & 2000 & Lidar & MHW \\
\hline \multirow[t]{8}{*}{ New England South } & $1975 / 1978$ & Air photo & HWL & 1844-1895 & T-sheet & HWL \\
\hline & 2000 & Lidar & MHW & 1934-1963 & T-sheet & HWL \\
\hline & & & & 1975-1978 & Air photo & HWL \\
\hline & & & & 1985-1997 & Air photo & HWL \\
\hline & & & & 2000 & Lidar & MHW \\
\hline & & & & 2003 & Air photo & HWL \\
\hline & & & & 2004 & Air photo & HWL \\
\hline & & & & 2006 & Air photo & HWL \\
\hline
\end{tabular}

'Dates listed cover all available data for the Mid-Atlantic region. For details about dates of shoreline data used at a specific location within a region, refer to the shoreline data files available for download in the companion online data report (Himmelstoss and others, 2010).

\section{Lidar-Derived Mean High Water (MHW) Shoreline}

Although in most cases the most recent shoreline used in this National Assessment is a lidar-derived shoreline, in a few areas an aerial photograph-derived shoreline that is more recent than the lidar data was available. In these cases, a lidarderived shoreline is still incorporated into the analysis, but it is not the most recent. The lidar data were collected by the USGS in cooperation with the National Aeronautics and Space Agency (NASA). This collaborative group has been using the NASA Airborne Topographic Mapper (ATM and ATMII) to map coastal areas since 1997 (Krabill and others, 2000; Sallenger and others, 2003). The data used in this study are part of the 2000 Fall East Coast Airborne Lidar Assessment of Coastal Erosion (ALACE) Project. The ATM surveys ground elevation using an elliptically rotating blue-green laser. GPS positions and inertial navigation systems are used to correct for aircraft pitch, roll, and heading, providing ground elevations with accuracies of about $\pm 15 \mathrm{~cm}$ (Sallenger and others, 2003). The lidar surveys used to extract shorelines for this report were conducted in 1997 and 2000.

To define the shoreline contour used, a shoreline defined as the operational MHW elevation contour was extracted from the lidar surveys using a method similar to the one developed by Stockdon and others (2002) (fig. 2). To determine the operational MHW elevation, the New England and Mid-Atlantic region was divided into five sections: Maine to Upper Cape Cod, Outer Cape Cod and Nantucket, Martha's Vineyard and 
Table 2b. Shorelines used to calculate short- and long-term change rates for the Mid-Atlantic region.

[HWL, high water line; MHW, mean high water; Lidar, light detection and ranging]

\begin{tabular}{|c|c|c|c|c|c|c|}
\hline \multirow[b]{2}{*}{ Region } & \multicolumn{3}{|c|}{$\begin{array}{l}\text { Short-Term Rate } \\
\text { (End Point) }\end{array}$} & \multicolumn{3}{|c|}{$\begin{array}{c}\text { Long-Term Rate } \\
\text { (Linear Regression) }\end{array}$} \\
\hline & Date $^{1}$ & Source & Type & Date $^{1}$ & Source & Type \\
\hline \multirow[t]{12}{*}{ Long Island } & 1983 & Air photo & HWL & 1830-1892 & T-sheet & HWL \\
\hline & 2000 & Lidar & MHW & $1902-1962$ & T-sheet & HWL \\
\hline & & & & $1970-1979$ & Air photo & HWL \\
\hline & & & & 1983 & Air photo & HWL \\
\hline & & & & 1988 & Air photo & HWL \\
\hline & & & & 1991-1999 & Air photo & HWL \\
\hline & & & & 2000 & Lidar & MHW \\
\hline & & & & 2001 & Lidar & MHW \\
\hline & & & & 2002 & Lidar & MHW \\
\hline & & & & 2005 & Lidar & MHW \\
\hline & & & & 2006 & Lidar & MHW \\
\hline & & & & 2007 & Lidar & MHW \\
\hline \multirow[t]{5}{*}{ New Jersey North } & 1977 & Air photo & HWL & $1836-1899$ & T-sheet & HWL \\
\hline & 2000 & Lidar & MHW & $1932-1953$ & T-sheet & HWL \\
\hline & & & & 1971 & Air photo & HWL \\
\hline & & & & 1977 & Air photo & HWL \\
\hline & & & & 2000 & Lidar & MHW \\
\hline \multirow[t]{5}{*}{ New Jersey South } & 1977 & Air photo & HWL & $1841-1899$ & T-sheet & HWL \\
\hline & 2000 & Lidar & MHW & 1933-1953 & T-sheet & HWL \\
\hline & & & & 1971 & Air photo & HWL \\
\hline & & & & 1977 & Air photo & HWL \\
\hline & & & & 2000 & Lidar & MHW \\
\hline \multirow[t]{5}{*}{ Delmarva North } & 1980 & Air photo & HWL & $1845-1882$ & T-sheet & HWL \\
\hline & $1997 / 2000$ & Lidar & MHW & 1903-1962 & T-sheet & HWL \\
\hline & & & & 1970-1979 & T-sheet & HWL \\
\hline & & & & $1980-1989$ & Air photo & HWL \\
\hline & & & & $1997-2000$ & Lidar & MHW \\
\hline \multicolumn{7}{|l|}{ Delmarva South and } \\
\hline \multirow[t]{4}{*}{ Southern Virgina } & 1980 & Air photo & HWL & $1851-1888$ & T-sheet & HWL \\
\hline & 1997 & Lidar & MHW & $1905-1979$ & T-sheet & HWL \\
\hline & & & & 1980 & Air photo & HWL \\
\hline & & & & 1997 & Lidar & MHW \\
\hline
\end{tabular}

'Dates listed cover all available data for the Mid-Atlantic region. For details about dates of shoreline data used at a specific location within a region, refer to the shoreline data files available for download in the companion online data report (Himmelstoss and others, 2010). 
the south shores of Massachusetts and Rhode Island, the south shore of Long Island, and New Jersey to the North Carolina border. For each section, the operational MHW elevation represents an average of MHW elevations from individual open-ocean or near open-ocean tide gages (Weber and others, 2005). The lidar-extracted MHW shoreline is not necessarily the same as a MHW shoreline surveyed by a licensed land surveyor. The operational MHW elevation used for the lidar shoreline is an average of the MHW elevations at several tide gages (see Weber and others, 2005). Furthermore, the lidar-extracted shoreline is intended only as a reference feature for measuring shoreline change, not as a basis for establishing legal boundaries.

Shorelines were extracted from cross-shore profiles, which consist of bands of lidar data $2 \mathrm{~m}$ wide in the alongshore direction and spaced every $20 \mathrm{~m}$ along the coast. For each profile, the seaward-sloping foreshore points were identified and a linear regression was fit through them (fig. 2b). The regression was evaluated at the operational MHW elevation (table 3) to yield the cross-shore position of the MHW shoreline. If the MHW elevation was obscured by water points, or if a data gap

$A$

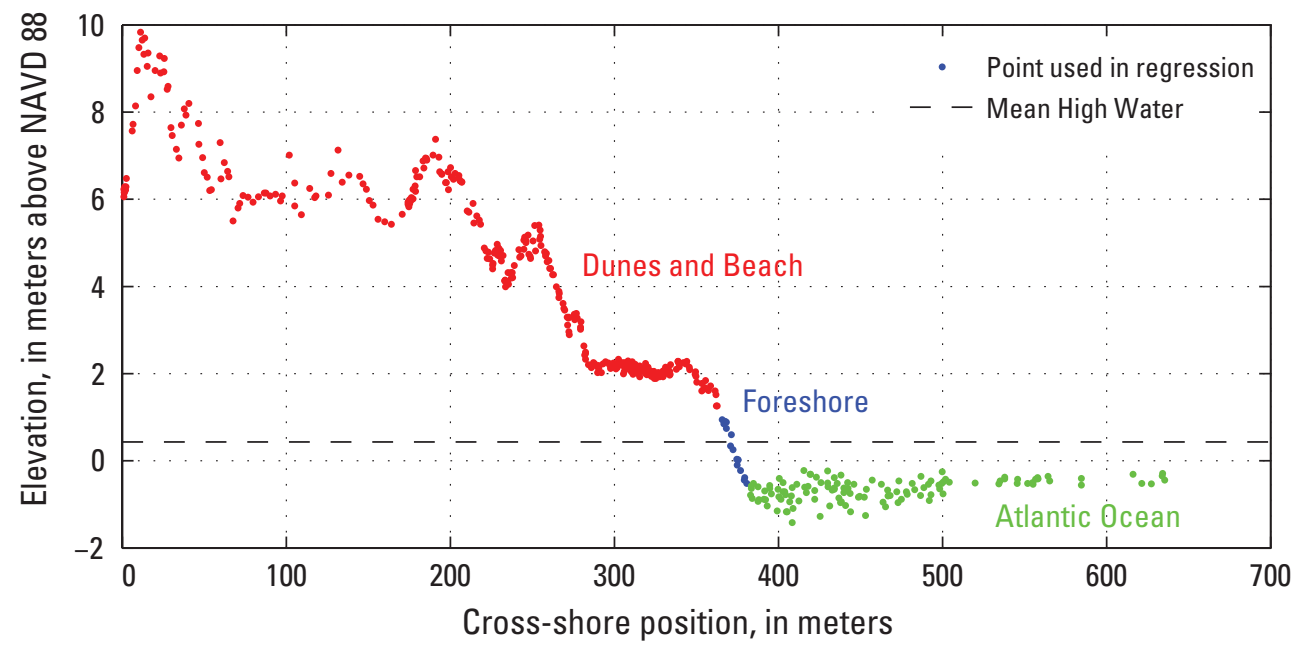

$B$

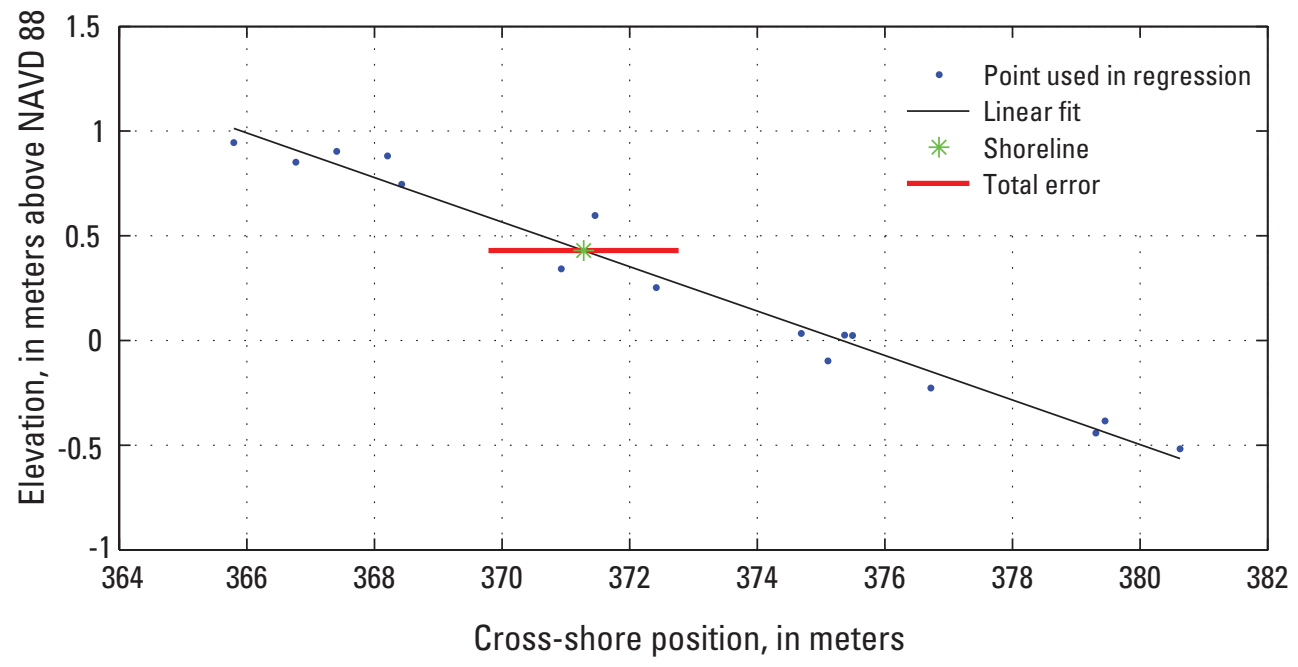

Figure 2. Graphs showing an example of a lidar profile from Island Beach State Park in New Jersey showing $(A)$ the entire cross-shore region and $(B)$ an expanded view of the foreshore region. $(A)$ Laser returns off the water's surface are seen as green symbols. Blue symbols indicate data points on the foreshore that were used in the linear regression to find the MHW shoreline. Red symbols indicate data points on the foreshore that were not used in the linear regression, as well as points along the rest of the beach and dunes. $(B)$ Linear regression through the selected foreshore points in $(A)$ is shown. The asterisk marks the cross-shore position of the operational MHW shoreline. The horizontal error bar represents the total error on the shoreline position. Modified from Stockdon and others (2002). 
Table 3. List of tide-gage measurements used to calculate mean high water (MHW) elevation.

[mean high water; $\mathrm{m}$, meters]

\begin{tabular}{|c|c|c|c|}
\hline & Region & $\begin{array}{l}\text { Average of } \\
\mathrm{MHW}(\mathrm{m})\end{array}$ & Geographic Area \\
\hline \multirow{7}{*}{ 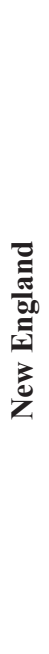 } & New England North & \multirow{2}{*}{1.22} & \multirow{2}{*}{ Cliff Island, ME, to Barnstable, MA } \\
\hline & Greater Boston & & \\
\hline & Cape Cod & 0.98 & Race Point, MA, to south end of Nauset Spit, MA \\
\hline & \multirow{2}{*}{ Massachusetts Islands } & 0.39 & $\begin{array}{l}\text { Monomoy Island, Cape Cod, MA, to Tom Never's Head, Nan- } \\
\text { tucket, MA }\end{array}$ \\
\hline & & 0.29 & $\begin{array}{l}\text { South shore of Nantucket (Tom Never's Head) to Martha's Vine- } \\
\text { yard, MA }\end{array}$ \\
\hline & \multirow{2}{*}{ New England South } & 0.36 & Acoaxet, MA, to Point Judith, RI \\
\hline & & 0.22 & Point Judith, RI, to Napatree Point, RI \\
\hline \multirow{6}{*}{ 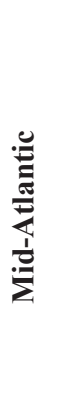 } & Long Island & 0.46 & Montauk Point, NY, to Rockaway Point, NY \\
\hline & New Jersey North & \multirow{2}{*}{0.43} & \multirow{2}{*}{ Sandy Hook, NJ, to Cape May Point, NJ } \\
\hline & New Jersy South & & \\
\hline & Delmarva North & \multirow{2}{*}{0.34} & \multirow{2}{*}{ Delaware Bay entrance to Chesapeake Bay entrance } \\
\hline & \multirow{2}{*}{$\begin{array}{l}\text { Delmarva South and Southern } \\
\text { Virginia }\end{array}$} & & \\
\hline & & 0.26 & Chesapeake Bay entrance to Cape Lookout, NC \\
\hline
\end{tabular}

was present at MHW, the linear regression was extrapolated to the operational MHW elevation. Repeating this procedure at successive profiles generated points that were then connected to create a continuous shoreline.

Because inland bays are not suitable sites for extraction of a lidar shoreline using the methods employed in this analysis and because this report focuses on the open-ocean coasts, shorelines of extensive bay areas such as Narragansett Bay, Chesapeake Bay, and Delaware Bay were not included in the shoreline change analysis. Also, lidar data were not available for all sandy beaches along the New England and Mid-Atlantic coast; gaps exist along the south shore of Cape Cod, and the north shore of Cape Cod from Sandwich to Provincetown.

\section{The Proxy-Datum Bias Correction between HWL and MHW Shorelines}

Inclusion of a lidar-derived shoreline in coastal change analyses represents a modern approach to the investigation of shoreline change. The pre-lidar historical shorelines used in this study were derived from topographic maps, aerial photographs, or field interpretations that use the HWL as the shoreline proxy. For more than 150 years, the HWL has served as the most commonly used shoreline because it could be visually identified in the field (Shalowitz, 1964; Anders and Byrnes, 1991). With advanced technologies, such as GPS and lidar, it is now possible to define the shoreline more objectively on the basis of an elevation or a tidal datum, such as MHW. Changing the shoreline definition from a proxybased physical feature that is uncontrolled in terms of an elevation datum (HWL) to a datum-based shoreline defined by an elevation contour (MHW) has important implications with regard to inferred changes in shoreline position and calculated rates of change.

Morton and others (2004) first compiled published and unpublished data to evaluate the horizontal and vertical differences in HWL determined from beach profiles, aerial photographs, or GPS surveys, and the MHW derived from beach profiles, GPS surveys, or lidar surveys. Hapke and others (2006) updated this dataset to include the most recent analyses available (table 4). The HWL and MHW 
Table 4. Absolute horizontal and vertical differences between high water line (HWL) and mean high water line (MHWL) shorelines.

[km, kilometers; $\mathrm{m}$, meters; modified from Morton and others, 2004]

\begin{tabular}{|c|c|c|c|c|c|c|c|c|}
\hline \multirow{2}{*}{ Location } & \multicolumn{2}{|c|}{ Survey Date } & \multirow{2}{*}{$\begin{array}{l}\text { Length } \\
\text { of } \\
\text { Coast } \\
(\mathrm{km})\end{array}$} & \multirow{2}{*}{$\begin{array}{c}\text { Number of } \\
\text { Observations }\end{array}$} & \multirow{2}{*}{$\begin{array}{c}\text { Average } \\
\text { Horizontal } \\
\text { Offset (m) }\end{array}$} & \multirow{2}{*}{$\begin{array}{l}\text { Average Verti- } \\
\text { cal Offset (m) }\end{array}$} & \multirow{2}{*}{$\begin{array}{c}\text { \%MHWL } \\
\text { with } \\
\text { Seaward } \\
\text { Offset } \\
\end{array}$} & \multirow[b]{2}{*}{ Data Source or Reference } \\
\hline & HWL & MHWL & & & & & & \\
\hline $\begin{array}{l}\text { Galveston } \\
\text { Island, TX }\end{array}$ & 01-27-95 & $01-27-95$ & Point & 1 & 18 & 0.6 & 100 & \multirow{5}{*}{ Morton and Speed, 1998} \\
\hline \multirow[t]{4}{*}{$\begin{array}{l}\text { North Padre } \\
\text { Island, TX' }\end{array}$} & 08-16-95 & 08-16-95 & 1.6 & 6 & 8 & 0.4 & 100 & \\
\hline & 09-14-95 & 09-14-95 & 1.6 & 6 & 8 & 0.2 & 100 & \\
\hline & 09-28-95 & 09-28-95 & 1.6 & 6 & 12 & 0.2 & 100 & \\
\hline & 10-06-95 & $10-06-95$ & 1.6 & 6 & 6 & 0.3 & 100 & \\
\hline Duck, NC ${ }^{2}$ & \multicolumn{2}{|c|}{$1994-1996^{2}$} & Point & 111 & 40 & 2.0 & 100 & Pajak and Leatherman, 2002 \\
\hline \multirow[t]{2}{*}{ Klipsan, WA ${ }^{3}$} & 05-26-99 & $05-28-99$ & 3.0 & 171 & 22 & 0.5 & 100 & \multirow{6}{*}{ Ruggiero and others, 2003} \\
\hline & $09-21-99$ & $09-24-99$ & 3.0 & 171 & 52 & 0.8 & 100 & \\
\hline \multirow[t]{3}{*}{$\begin{array}{l}\text { Ocean Shores, } \\
\text { WA }^{3}\end{array}$} & 05-26-99 & 05-28-99 & 4.0 & 200 & 23 & 1.0 & 100 & \\
\hline & 07-27-99 & $07-22-99$ & 4.0 & 200 & 8 & 0.2 & 100 & \\
\hline & 05-06-01 & 05-07-01 & 4.0 & 200 & 30 & 1.0 & 100 & \\
\hline $\begin{array}{l}\text { Oysterville, } \\
\text { WA }^{3}\end{array}$ & $09-21-99$ & $09-10-99$ & 3.5 & 201 & 49 & 0.9 & 100 & \\
\hline \multirow[t]{5}{*}{$\begin{array}{l}\text { Assateague } \\
\text { Island, } \\
\mathrm{MD} / \mathrm{VA}^{4}\end{array}$} & \multirow{3}{*}{$\begin{array}{c}03-16-98, \\
03-17-98 \\
09-29-99 \\
10-28-99 \\
06-13-01 \\
06-14-01\end{array}$} & 04-03-98 & 58.6 & 1,172 & 11 & 0.7 & 99 & \multirow{4}{*}{$\begin{array}{l}\text { M. Byrnes, Coastal Research } \\
\text { and Engineering, Inc., oral } \\
\text { commun., } 2007\end{array}$} \\
\hline & & $10-01-99$ & 60.0 & 1,200 & 20 & 1.6 & 100 & \\
\hline & & 06-05-01 & 52.4 & 1,049 & 8 & 0.6 & 92 & \\
\hline & $10-01-02$ & $09-12-02$ & 47.7 & 953 & 22 & 1.4 & 98 & \\
\hline & $05-06-02$ & 05-06-02 & 47 & 470 & 18.8 & $1.2-1.3$ & 100 & Moore and others, 2006 \\
\hline
\end{tabular}

\footnotetext{
${ }^{1}$ Simultaneous measurement of HWL and MHWL at beach profiles coordinated with tide-gage measurements

${ }^{2}$ Video camera projections of HWL for 111 days during a 3-year period and MHWL from generalized beach profiles

${ }^{3}$ Nearly simultaneous aerial photographs (HWL) and GPS surveys (MHWL)

${ }^{4}$ Nearly simultaneous GPS (HWL) and lidar surveys (MHWL)
}

positions were established at the same time, or within a few weeks of one another, at multiple sites around the United States where the beach and wave characteristics are diverse. The HWL and MHW positions are compared with the assumption that the observed proxy-datum offsets are entirely artifacts of shoreline definition and are not related to actual changes in the beach profile due to sediment transport (erosion or accretion processes) between the survey dates. This is a relatively safe assumption considering the short intervals between surveys or the knowledge that a particular shoreline segment is relatively stable. Moore and others (2006) avoided the need for this assumption by deriving HWL and MHW shorelines from aerial photography and lidar data collected during the same tidal cycle.
The average absolute horizontal and vertical offsets between the HWL and MHW range from a few meters to more than $50 \mathrm{~m}$, and vertical offsets can be as much as $2 \mathrm{~m}$ (table 4). Most of the horizontal offsets are less than $20 \mathrm{~m}$, and most of the vertical offsets are less than $1 \mathrm{~m}$. Offsets are typically greatest on relatively flat beaches where large waves produce high wave run-up (for example, southwest Washington). Offsets are smallest where beaches are relatively steep and wave run-up is low. For the data analyzed by Morton and others (2004), the percentage of MHW shorelines offset seaward of the HWL exceeded 98 percent within the 17 survey dates (table 4). This nearly systematic unidirectional horizontal offset between the HWL and MHW causes shoreline positions and calculated rates 
of change to appear to have slower erosion or faster accretion than is indicated by actual shoreline movement, or a change from erosion to accretion that did not actually occur.

Recent studies by Hapke and others (2006), Moore and others (2006) and Ruggiero and List (2009) illustrate that, overall, the importance of incorporating a proxy-datum offset into shoreline change analysis depends on several factors, including the magnitude of the offset, the length of time over which rates are being measured, and the statistical significance of the shoreline change rates. The proxy-datum offset is particularly important when averaging shoreline change rates alongshore. Because the proxy-datum offset is a bias that virtually always acts in the same direction, the error associated with the apparent shoreline change rate shift is not canceled during averaging. It is important to quantify this bias in order to resolve the shift it can cause in reported rates. The shoreline change rates presented in this report have accounted for and incorporated the proxy-datum bias into the rate calculations using the latest version of the Digital Shoreline Analysis System (DSAS). The specific methodology used to determine the proxy-datum bias values is detailed in Ruggiero and List (2009) and described briefly below.

Comparison of HWL shorelines and a MHW datum-based shoreline for a single-day survey on Assateague Island (Moore and others, 2006) revealed an average horizontal offset between shoreline indicators of $18.8 \mathrm{~m}$ (table 4). Vertical offsets were also substantial and were strongly correlated with foreshore beach slope. A simple total water level model, which combines the effects of tidal variations and wave run-up (Ruggiero and others, 1996; Ruggiero and others, 2001; Ruggiero and others, 2003), successfully reproduced these vertical offsets, indicating that the proxy-datum offset may be governed primarily by wave run-up. In order to estimate the proxy-datum bias for the New England and Mid-Atlantic region, we use the approach outlined in Ruggiero and List (2009), which includes the improvement wave run-up formulation of Stockdon and others (2006). The horizontal offset between HWL and MWH shorelines can be estimated by

Equation (1)

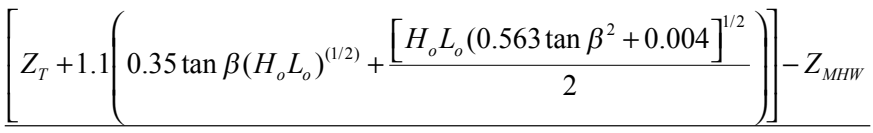

$\tan \beta$

where $Z_{T}$ is the tide level, $\tan \beta$ is the beach slope, $H_{o}$ is the deepwater significant wave height, and $L$ is the deepwater wave length given by linear theory as $\mathrm{gT}^{2} / 2 \pi$, where $\mathrm{g}$ is the acceleration due to gravity and $\mathrm{T}$ is the peak wave period.

In order to calculate the bias, long-term best estimates and measures of uncertainty are derived for beach slope, wave height, wave length, and tide level. The best estimate for beach slope was derived by averaging individual lidar cross-shore profile slope estimates within 1-km blocks along the coast. The long-term mean wave height and length are used as the bestestimate values in the bias calculation. The long-term mean wave height is derived from averaging USACE Wave Information Studies (WIS) hindcasts whereas the long-term mean wave length is averaged from long-term buoy records (NDBC and CDIP) along the New England and Mid-Atlantic coast. Finally, the best estimate of the tide level responsible for generating HWL shorelines is used as the elevation of MHW (see table 3) (Weber and others, 2005). The proxy-datum bias varies widely alongshore, but averages $8.6 \mathrm{~m}$ through the NEMA study area.

\section{Uncertainty in the Proxy-Datum Bias}

Because each of the variables in equation (1) has associated uncertainties, the proxy-datum bias correction also has an uncertainty. The measures of uncertainty for the beach slope, wave height, and wave length are estimated as the difference between the 95-percent exceedance statistic and the 50-percent exceedance statistic of the cumulative distribution for each variable. This provides a 90-percent confidence interval (CI) for each of the three cumulative distributions. The uncertainty of assuming that the tide is responsible for producing the HWL shoreline proxy, and that it is approximately the elevation of $\mathrm{MHW}$, is calculated by subtracting MHW from is calculated by subtracting MHW from mean high high water (MHHW). Using these values of uncertainty for each of the variables in equation (1), the bias uncertainty is calculated using the procedure described in Ruggiero and List (2009), following Taylor (1997).

\section{Use of the Proxy-Datum Bias and Bias Uncertainty in Shoreline Change Analysis}

The proxy-datum bias and bias uncertainty are calculated at each of the 1-km blocks in which the average beach slope has been calculated. Version 4.1 of DSAS can incorporate proxy-offset values into proxy-datum bias shifts to reconcile the horizontal offsets between the MHW and HWL shoreline proxies described above. The operational MHW shoreline points extracted from the lidar data at 20-m alongshore spacing are written to a table containing xy locations and three associated values: (1) shoreline position uncertainty, (2) the proxy-datum bias, and (3) the proxydatum bias uncertainty. The proxy-datum bias is incorporated in the shoreline change statistics calculations to correct for datum offsets between the MHW and HWL shorelines (Himmelstoss, 2009), and the uncertainty values are used in the estimation of shoreline change uncertainty (see High Water Line Shoreline Position Uncertainty).

\section{Estimation of Shoreline Position Uncertainty}

The uncertainty of calculated rates of shoreline change depends on the total shoreline position uncertainty. Shoreline 
position uncertainties from sources that can be quantified are described below for both HWL- and MHW-type shorelines.

A potentially large source of shoreline position uncer-

tainty that we do not quantify results from the local short-term variability of true shoreline positions (Morton, 1991; Douglas and Crowell, 2000). Along the New England and Mid-Atlantic coast, as in many locales worldwide, there are pronounced cyclical and event-driven erosion and accretion of the shoreline. This variability is driven by variations in wave conditions from summer to winter, years with severe as opposed to average storms or swells, and episodic events like hurricanes and "nor'easters" (extratropical cyclones). The seasonal shoreline variability also has a high spatial variability, depending on the orientation of the coast with respect to the wave direction and effects of refraction or reflection from headlands and manmade structures. As a result, calculating an uncertainty term to quantify seasonal shoreline variability for regionally averaged shoreline change rates is difficult. Site-specific, temporally dense data are required to evaluate short-term shoreline variability. The lack of reliable high-frequency data regarding short-term variability (of true shoreline position) at most coastal sites limits the ability to quantify this uncertainty as part of the overall shoreline position uncertainty. Because of the lack of accurate, systematic data regarding the seasonal variation of the shoreline along the New England and Mid-Atlantic coast, the uncertainty values reported here (tables $6 \mathrm{a}$ and $6 \mathrm{~b}$ ) do not include an uncertainty term for the seasonal shoreline position variability in the quantification of uncertainties associated with the regionally averaged shoreline change rates.

\section{HWL Shoreline Position Uncertainty}

Anders and Byrnes (1991), Crowell and others (1991), Thieler and Danforth (1994), and Moore (2000) provided general estimates of the typical HWL measurement uncertainties associated with (1) mapping methods and materials for historical shorelines, (2) the registration of shoreline position relative to geographic coordinates, and (3) shoreline digitizing. As in the methods outlined by Crowell and others (1993), we identify five uncertainty terms for HWL-type shorelines: georeferencing uncertainty $\left(U_{g}\right)$, digitizing uncertainty $\left(U_{d}\right)$, T-sheet survey uncertainty $\left(U_{t}\right)$, air photo uncertainty $\left(U_{a}\right)$, and the uncertainty of the high water line at the time of survey, which is found as the proxy-datum bias uncertainty $\left(U_{p d}\right)$.

The georeferencing uncertainty represents the elected maximum acceptable RMS error for T-sheets at a scale of 1:20,000 in this study. The georeferencing uncertainty, \pm 4.0 $\mathrm{m}$, is applied to the historical shorelines that are derived from T-sheets only (1800s-1980s). The digitizing uncertainty, $\pm 1.0 \mathrm{~m}$, reflects the maximum error specified in past studies (Anders and Byrnes, 1991; Crowell and others, 1991; Moore, 2000), and is applied to all HWL shorelines. The maximum T-sheet survey uncertainty, determined by Shalowitz (1964), incorporates all of the errors associated with the mapping process, including distance to rodded points, plane-table position, and identification of the HWL. The T-sheet survey uncertainty is applied to all historical shorelines; however, the uncertainty associated with the 1960s-to-1980s-era T-sheets $( \pm 3.0 \mathrm{~m})$ is considerably lower than that associated with the older T-sheets from the 1800 s to the $1950 \mathrm{~s}( \pm 10.0 \mathrm{~m})$. This difference is based on findings by Ruggiero and others (2003), as well as the fact that more recent shorelines are derived from aerial photos or other sources. The air-photo uncertainty, \pm 3.0 $\mathrm{m}$, is applied to shoreline positions from 1990s-to-2000s air photos that were digitized as part of this study. A previously unreported uncertainty term in shoreline change analyses is the uncertainty in HWL shorelines due to variations in water levels. The uncertainty of the proxy-datum bias, found using equation 1 and the uncertainty estimation techniques of Taylor (1997), can be shown to be equivalent to the uncertainty of the HWL shoreline due to water-level variations (Ruggiero and List, 2009). The HWL uncertainty varies alongshore as a function of the variables in equation 1 , but averages $\pm 4.5 \mathrm{~m}$ in our study. For each HWL shoreline position, the total uncertainty is found as the square root of the sum of squares (Taylor, 1997) of the relevant uncertainty terms, based on an assumption that each term is random and independent of the others. For shorelines derived from the 1800s-to-1980s T-sheets, the total shoreline position uncertainty at each transect, $i$, is:

Equation (2)

$$
U_{p_{i}}=\sqrt{U_{g_{i}}{ }^{2}+U_{d_{i}}{ }^{2}+U_{t_{i}}{ }^{2}+U_{p d_{i}}^{2}}
$$

and the uncertainty for the 1990s-to-2000s air photos is:

Equation (3)

$$
U_{p_{i}}=\sqrt{U_{d_{i}^{2}}^{2}+U_{a_{i}}^{2}+U_{p d_{i}^{2}}^{2}}
$$

The shoreline position uncertainties given by equations (2) and (3) vary alongshore because of a spatially varying $U_{p d}$.

Values of $U_{p_{i}}$ are available in the companion online data report (Himmelstoss and others, 2010). For reference, the average values of uncertainty terms and the total average shoreline position uncertainty, $U_{p}$, for each shoreline type are given in table 5 . Note that these average values are not used to determine shoreline change uncertainty (see Estimation of Shoreline Change Rate Uncertainty).

\section{Lidar-Derived MHW Shoreline Position Uncertainty}

Each MHW lidar shoreline position, derived at a 20-m alongshore spacing, has an associated uncertainty that includes three components. The first is the 95-percent CI associated with the regression estimate in the determination of the linear regression MHW position for each cross-shore profile of lidar point cloud data. The second uncertainty component is the uncertainty associated with the raw lidar data position, especially the elevation. Sallenger and others (2003) determined 
that the vertical accuracy of NASA's Airborne Topographic Mapper lidar system is approximately $\pm 15 \mathrm{~cm}$, which can be thought of as a bias in lidar elevation (not random error). This vertical uncertainty is converted to a horizontal shoreline position uncertainty using the beach slope determined by the linear regression. The third component of the total uncertainty is the uncertainty due to extrapolation (the difference between an observed position and a position predicted on a projected regression line). Although the 95-percent CI on MHW position is larger when extrapolation is used, this method assumes that the foreshore slope is constant from the limit of the lidar data to the position of MHW. Because this may not be the case, we find an additional MHW uncertainty term by assuming a certain degree of cross-shore slope variability and finding the corresponding variability in extrapolated MHW position. The slope variability was found through an extensive compilation of foreshore slope variability extracted from more than 1,200 $\mathrm{km}$ of coastal lidar data from the Northwest, Northeast, and Mid-Atlantic regions of the United States. The three uncertainty terms - the 95-percent CI on MHW from the linear regression, the elevation-bias uncertainty, and the extrapolation uncertainty - are then added using the square root of the sum of the squares to give the $U_{p_{i}}$ for the MHW shoreline at each lidar profile. This total uncertainty for MHW shorelines varies alongshore on a profile-by-profile basis, with the NEMA-average value of $\pm 2.3 \mathrm{~m}$ (table 5).

\section{Calculation and Interpretation of Shoreline Change Rates}

Rates of long-term shoreline change at each transect, $R_{i}$, were generated using the DSAS version 4.1, an ArcGIS tool developed by the USGS (Thieler and others, 2009). The tool is a freely available application designed to work within the ESRI ArcGIS software. For this study, DSAS is used to generate orthogonal transects at $50-\mathrm{m}$ spacing along the coast and to consequently calculate change statistics (linear regression, weighted linear regression, and end-point rate). Information derived from lidar data at a 20 -m alongshore spacing including: MHW shoreline positions, the proxy-datum bias, and the proxy-datum bias uncertainty, is interpolated onto the 50-m DSAS transect spacing. Linear regression is the most commonly applied statistical technique for expressing shoreline movement and estimating rates of change (Crowell and Leatherman, 1999) where there is a statistically valid number of samples. Linear regression fails to recognize the potential for temporal differences in trend (trend reversals) and accelerations or decelerations (Fenster and others, 1993; Fenster and Dolan, 1994; Morton, 1991; Morton, 1996), so average trends and rates of shoreline change in this study were calculated for both long-term (entire period) and short-term (most recent) time scales to capture potential changes in shoreline change rates or trends.

Table 5. Average uncertainties for the New England and Mid-Atlantic shorelines. [-, not applicable; m, meters]

\begin{tabular}{|c|c|c|c|c|}
\hline Measurement Uncertainty (meters) & 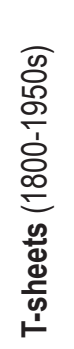 & 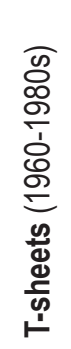 & 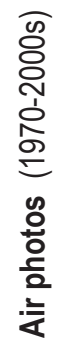 & 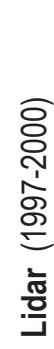 \\
\hline Georeferencing $\left(U_{g}\right)$ & 4 & 4 & - & - \\
\hline Digitizing $\left(U_{d}\right)$ & 1 & 1 & 1 & - \\
\hline T-sheet survey $\left(U_{t}\right)$ & 10 & 3 & - & - \\
\hline Air photo $\left(U_{a}\right)$ & - & - & 3 & - \\
\hline Uncertainty of the High Water Line $\left(U_{p d}\right)$ & 4.5 & 4.5 & 4.5 & - \\
\hline Lidar total position uncertainty $\left(U_{p}\right)$ & - & - & - & 2.3 \\
\hline otal shoreline position uncertainty $\left(U_{p}\right)(\mathrm{m})$ & 11.7 & 6.8 & 5.5 & 2.3 \\
\hline
\end{tabular}


Table 6a. Long-term shoreline change rate uncertainties for New England and Mid-Atlantic regional averages.

$[\mathrm{m} / \mathrm{yr}$, meters per year; $\mathrm{m}$, meters; uncertainty numbers in red are confidence interval values that are less than the average rate indicating that the average rate is significant]

\begin{tabular}{|c|c|c|c|c|c|c|}
\hline & Region & $\begin{array}{c}\text { Average rate } \\
\qquad(\mathrm{m} / \mathrm{yr})\end{array}$ & $\begin{array}{l}\text { Number of } \\
\text { transects }\end{array}$ & $\begin{array}{l}\text { Average } \\
\text { uncertainty } \\
\text { (m) }\end{array}$ & Independent $\mathbf{n}$ & $\begin{array}{l}\text { Uncertainty reduced for } \\
\text { independent } n \\
\text { (m) }\end{array}$ \\
\hline \multirow{5}{*}{ 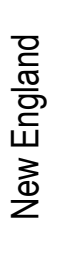 } & New England North & 0.1 & 1,642 & 0.4 & 77 & 0.05 \\
\hline & Greater Boston & -0.09 & 2,005 & 0.3 & 100 & 0.03 \\
\hline & Cape Cod & -0.4 & 1,666 & 1.5 & 10 & 0.5 \\
\hline & Massachusetts Islands & -1.4 & 1,775 & 0.6 & 43 & 0.09 \\
\hline & New England South & -0.2 & 1,136 & 0.2 & 45 & 0.03 \\
\hline \multirow{8}{*}{ 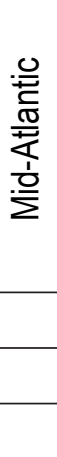 } & Long Island & 0.08 & 3,518 & 0.6 & 11 & 0.2 \\
\hline & New Jersey North & -0.6 & 2,234 & 0.9 & 22 & 0.2 \\
\hline & New Jersey South & 0.8 & 1,408 & 1.3 & 22 & 0.3 \\
\hline & Delmarva North & -0.5 & 2,235 & 0.7 & 19 & 0.2 \\
\hline & $\begin{array}{c}\text { Delmarva South and } \\
\text { Southern Virginia }\end{array}$ & -2.9 & 2,165 & 1.7 & 10 & 0.5 \\
\hline & New England total & -0.4 & 8824 & 0.6 & 39 & 0.1 \\
\hline & Mid-Atlantic total & -0.6 & 11,560 & 1.0 & 61 & 0.1 \\
\hline & Total & -0.5 & 19,784 & 0.8 & 91 & 0.09 \\
\hline
\end{tabular}

Table 6b. Short-term shoreline change rate uncertainties for New England and Mid-Atlantic regional averages.

$[\mathrm{m} / \mathrm{yr}$, meters per year; $\mathrm{m}$, meters; uncertainty numbers in red are confidence interval values that are less than the average rate indicating that the average rate is significant]

\begin{tabular}{|c|c|c|c|c|c|c|}
\hline & Region & $\begin{array}{c}\text { Average rate } \\
\text { (m/yr) }\end{array}$ & $\begin{array}{l}\text { Number of } \\
\text { transects }\end{array}$ & $\begin{array}{c}\text { Average } \\
\text { uncertainty } \\
\text { (m) }\end{array}$ & Independent $\mathbf{n}$ & $\begin{array}{l}\text { Uncertainty reduced for } \\
\text { independent } \mathbf{n} \\
\text { (m) }\end{array}$ \\
\hline \multirow{5}{*}{ 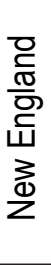 } & New England North & -0.4 & 414 & 0.3 & 7 & 0.1 \\
\hline & Greater Boston & -0.1 & 1,381 & 0.3 & 32 & 0.06 \\
\hline & Cape Cod & 0.3 & 1,665 & 0.2 & 6 & 0.09 \\
\hline & Massachusetts Islands & -0.8 & 1,759 & 0.3 & 8 & 0.1 \\
\hline & New England South & -0.09 & 1,135 & 0.3 & 7 & 0.1 \\
\hline \multirow{8}{*}{ 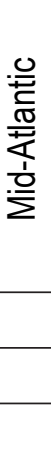 } & Long Island & 0.8 & 3,210 & 0.4 & 20 & 0.09 \\
\hline & New Jersey North & 0.5 & 2,108 & 0.3 & 20 & 0.06 \\
\hline & New Jersey South & 0.2 & 1,349 & 0.4 & 20 & 0.1 \\
\hline & Delmarva North & -0.8 & 2,244 & 0.4 & 70 & 0.04 \\
\hline & $\begin{array}{c}\text { Delmarva South and } \\
\text { Southern Virginia }\end{array}$ & -2.7 & 2,074 & 0.5 & 12 & 0.1 \\
\hline & New England total & -0.2 & 6,354 & 0.3 & 11 & 0.09 \\
\hline & Mid-Atlantic total & -0.3 & 10,985 & 0.4 & 16 & 0.1 \\
\hline & Total & -0.3 & 17,339 & 0.4 & 11 & 0.1 \\
\hline
\end{tabular}




\section{End-Point Rates (Short-Term)}

Short-term rates of shoreline change were calculated at each transect using an end-point rate between a shoreline position from the time period 1971-84 and the most recent shoreline (1997-2006) to provide an approximately 30-yr short-term rate (see tables $2 \mathrm{a}$ and $2 \mathrm{~b}$ for data sources). The end-point rate is found as the difference in shoreline position between the 2 shoreline years, divided by the time between surveys. The proxy-datum bias was applied to remove the bias between the HWL and MHW shorelines by adjusting the horizontal distance of the MHW shoreline before rates were calculated. For an end-point rate, there is no assumption that the rate was linear between the 2 survey years; the rate represents the net change between the surveys, annualized to facilitate comparisons with long-term rates found through linear regression, described below.

\section{Linear Regression Rates (Long-Term)}

Long-term rates of shoreline change were calculated at each transect as the slope of the linear regression through all shoreline positions from the earliest (1800s) to the most recent (generally the lidar-derived shoreline). The proxy-datum bias was used to adjust the distance of the MHW shoreline prior to rate calculation, in order to remove the bias between the HWL and MHW methods of delineating shoreline position.

A minimum of 4 shoreline years at each DSAS transect was required for the calculation of long-term rates of change. One of the shorelines must be the lidar-surveyed shoreline. Fewer than four shorelines can result from one or more of the following conditions (fig. 3): (1) the position of an inlet or stream mouth has changed or migrated, (2) shoreline segments are missing (data gaps), (3) a harbor or other coastal structure eliminated one or more of the shorelines, and (4) no

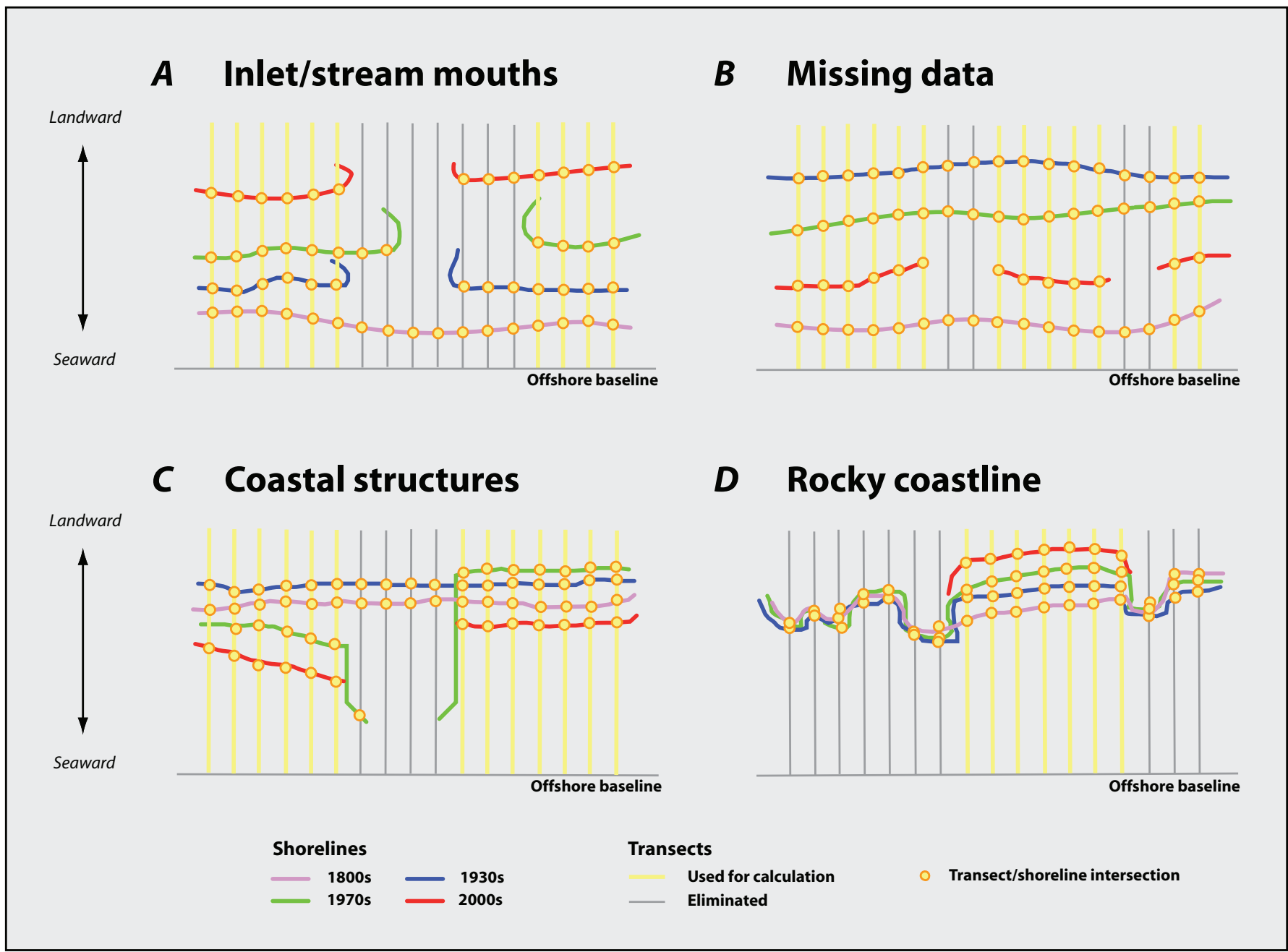

Figure 3. Schematic diagrams showing examples of common conditions where transects are eliminated in the absence of four shoreline intersections: $(A)$ inlet/stream mouths, $(B)$ missing data, $(C)$ coastal structures, and $(D)$ rocky coastline. 
lidar-derived shoreline is available for rocky coasts. Table 2 indicates the shoreline dates and sources used for the linear regression in each region; the dates that cover specific coastal locations can be found in Himmelstoss and others (2010).

The linear regression method of determining shoreline change rates does assume a linear trend of change between the earliest and latest shoreline dates. However, there are clearly areas where such a linear trend does not exist - that is, shoreline change rates have not remained constant through time. In these cases it is expected that the resulting linear fit to the data would be poorer, and the shoreline change rate uncertainty, described below, would be higher.

\section{Estimation of Shoreline Change Rate Uncertainty}

\section{Rate Uncertainty at Individual Transects}

The uncertainty of a single transect's end-point shoreline change rate is found as the quadrature addition of the uncertainties for each year's shoreline position, divided by the number of years between the shoreline surveys:

Equation (4)

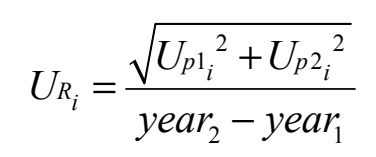

where $U_{p 1}$ and $U_{p 2}$ are the shoreline position uncertainties of the first $\left(\right.$ year $\left._{1}\right)$ and second $\left(\right.$ year $\left._{2}\right)$ shorelines, respectively, at transect $i$, found through equation (2) or (3). For the linear regression method, the uncertainty of a single transect's shoreline change rate, $U_{R_{i}}$, is found here as the 90 -percent CI on the linear regression slope.

\section{Regionally Averaged Rate Uncertainty}

In addition to shoreline change rates and rate uncertainties at individual transects, this report provides regionally averaged rates, $\bar{R}$, and the associated average rate uncertainty (tables 6a and 6b), as a measure of broader scale trends. The procedure for finding the uncertainty associated with regionally averaged shoreline change rates, described below, is the same for both the end-point and linear regression methods.

A common method for finding the uncertainty on a mean value is based on variations in the measurement values themselves, typically using a t-distribution confidence interval on the mean of a limited sample from a population found as:

Equation (5)

$$
C_{t}= \pm t_{\alpha(2), v} s_{\bar{x}}
$$

where $t_{\alpha(2), v}$ is the two-tailed t-distribution value in which $\alpha$ is the confidence level and $v$ is the degrees of freedom, and $s_{\bar{x}}=s / \sqrt{n}$ is the standard error on the sample mean with $s$ the standard deviation of the sample and $n$ the sample size. The regionally averaged rates of change presented in this report, however, are not a limited sample from a larger population as assumed in equation (5). The mean shoreline change for a region is essentially a measure of the whole population, given the 50-m spacing of the DSAS transects. Therefore, the uncertainty associated with regional variations in shoreline change rate is negligible. However, a much larger source of uncertainty arises from the uncertainty of each individual shoreline change value used in the mean. Each transect's value of shoreline change rate, $R_{i}$, has an uncertainty, $U_{R_{i}}$, which can be used to estimate the uncertainty of the regionally, averaged shoreline change $\bar{R}$.

Given that regionally averaged shoreline change rate is found as:

Equation (6)

$$
\bar{R}=\sum_{i}^{n} R_{i} / n
$$

where $n$ is the number of transects within the region, the simplest method of finding the associated uncertainty is:

Equation (7)

$$
\bar{U}_{R}=\frac{1}{n} \sum_{i}^{n} U_{R_{i}}
$$

However, in this method it is assumed that there is no advantage in having multiple transects - that is, there is no cancellation of uncertainties between transects due to random variability. Shoreline change rate uncertainties found with equation (7) are, in most cases, larger than the regionallyaveraged shoreline change rate found by equation (6). We consider equation (7) to result in an overestimate of the uncertainty because some cancellation of uncertainties is likely in a regional analysis.

An alternative method of estimating uncertainty can be applied if we assume that each transect's uncertainty is random and independent of all the other transects. In this case the uncertainty associated with regionally averaged shoreline change rates can be found as:

Equation (8)

$$
\bar{U}_{R q}=\frac{1}{n} \sqrt{\sum_{i}^{n} U_{R_{i}^{2}}^{2}}
$$

which represents a quadrature average of uncertainties following Taylor (1997). Quadrature average results in very small values of uncertainty, on the order of \pm 1 to $2 \mathrm{~cm}$, and is likely an underestimate of the uncertainty because it is unlikely that all transect uncertainties are independent of all the others. 
A better estimate of the regionally averaged shoreline change rate uncertainty likely falls between the extremes of equations (7) and (8), whereby each transect rate uncertainty is partially independent of the others. To estimate the regionally averaged uncertainty of partially independent transect rates, we first evaluate the effective number of independent uncertainty values, $n^{*}$. Following Garrett and Toulany (1981), we find n* based on the spatially lagged auto-correlation of $U_{R_{i}}$. In all regions, this method results in a large reduction in the original sample size, $\mathrm{n}$, as shown in tables $6 \mathrm{a}$ and $6 \mathrm{~b}$.

Substitution of $n *$ into equation (8) is not possible without knowledge of which values of $U_{R_{l}}$ represent the independent samples. Using $\mathrm{n} *$ in the denominator of equation (8) while finding the quadrature sum of all the values of $U_{R_{i}}$ in the numerator gives a much larger uncertainty than the uncertainty calculated using equation (7). We use a simplified version of equation (8) to find an average rate uncertainty which accounts for the reduced effective sample size, $\mathrm{n}^{*}$. When all $U_{R_{i}}$ values are equal, the right-hand side of equation (8) reduces to $\bar{U}_{R} / \sqrt{n}$. Assuming that the $U_{R_{i}}$ of a region can be represented by $\bar{U}_{R}$, we find the uncertainty of a regionally averaged change rate as:

Equation (9)

$$
\bar{U}_{R q^{*}}=\frac{1}{\sqrt{n^{*}}} \bar{U}_{R}
$$

Equation (9) is used to estimate the uncertainty of regionally averaged shoreline change rates in this report, with values given in tables $6 \mathrm{a}$ and $6 \mathrm{~b}$.

\section{Human Beach Alterations that Influence Rates of Change}

Differentiating between natural rates of erosion and the influences of beach nourishment and engineering structures is difficult because few studies have been conducted to address these issues specifically. In addition, available data may be inadequate to address these questions because the number of available shoreline positions immediately before, after, and between nourishment projects or structure emplacement is insufficient. Human responses to shoreline erosion are included in the discussion of the results of the shoreline change analysis where possible.

Attempts to stabilize the shore can greatly influence rates of shoreline change. Activities such as beach nourishment or emplacement of shoreline stabilization structures tend to alter coastal processes, sediment transport, and shoreline position. For example, beach nourishment artificially causes rapid, temporary shoreline accretion. Depending on the frequency of beach nourishment, the placement of large volumes of sand on the beach will bias the rates of observed shoreline change toward accretion or stability, even though the natural beach, in the absence of nourishment, may have an erosional trend. In addition, the emplacement of shoreline protection structures such as seawalls, bulkheads, and revetments can result in both active and passive erosion of the beach. In the case of passive erosion, the back-beach area is fixed by a structure, and the beach in front gradually narrows. Eventually erosion ceases (until the structure fails), thus indicating a stable shoreline in the shoreline change record. Active erosion associated with shoreline protection structures refers to the acceleration of shoreline erosion in front of a structure caused by the alteration of wave, tide, and current patterns. Other coastal modifications that influence the shoreline change trends are structures, such as groins and jetties, that disrupt alongshore sediment transport. Depending on the timing of emplacement relative to the shoreline database, there will be a zone of accretion updrift from shore-perpendicular structures and erosion on the downdrift side. Many areas of the New England and Mid-Atlantic region, especially from New Jersey through Virginia, have extensive groin fields. Stabilized inlets are more common from Long Island south to Maryland (fig. 4).

Pilkey and Clayton (1989) and Valverde and others (1999) provide summaries of beach nourishment projects on U.S. East Coast barrier islands through 1986 and 1996, respectively, that date back as far as 1923. Haddad and Pilkey (1998) compiled similar information for the New England coast and documented nourishment episodes up to 1996. The Program for the Study of Developed Shorelines (PSDS) at Western Carolina University currently maintains an electronic database of nationwide nourishment projects (http://www.wcu.edu/1038.asp) that is updated regularly and includes projects conducted as recently as 2007 . These records were used to help identify shoreline segments that have been influenced by beach nourishment. Valverde and others (1999) show that from the 1920s through the 1990s, the total volume of nourishment sand placed on East Coast barrier beaches increased exponentially. Based on the current PSDS records, more than $200,000,000 \mathrm{~m}^{3}$ of material was placed on New England and Mid-Atlantic beaches from 1923 to 2007, and this number continues to grow.

\section{Geology and Geomorphology of the New England and Mid-Atlantic Coasts}

\section{General Geologic Setting}

The East Coast of the United States is a trailing margin coastline (sometimes referred to as a "passive margin"), a tectonic description that indicates the coastline does not coincide with a plate boundary. Trailing margin coasts typically have a wide continental shelf and predominantly low-lying coastal landforms (Inman and Nordstrom, 1971). Regionally, the variation in landform type is a function of geomorphic province. 


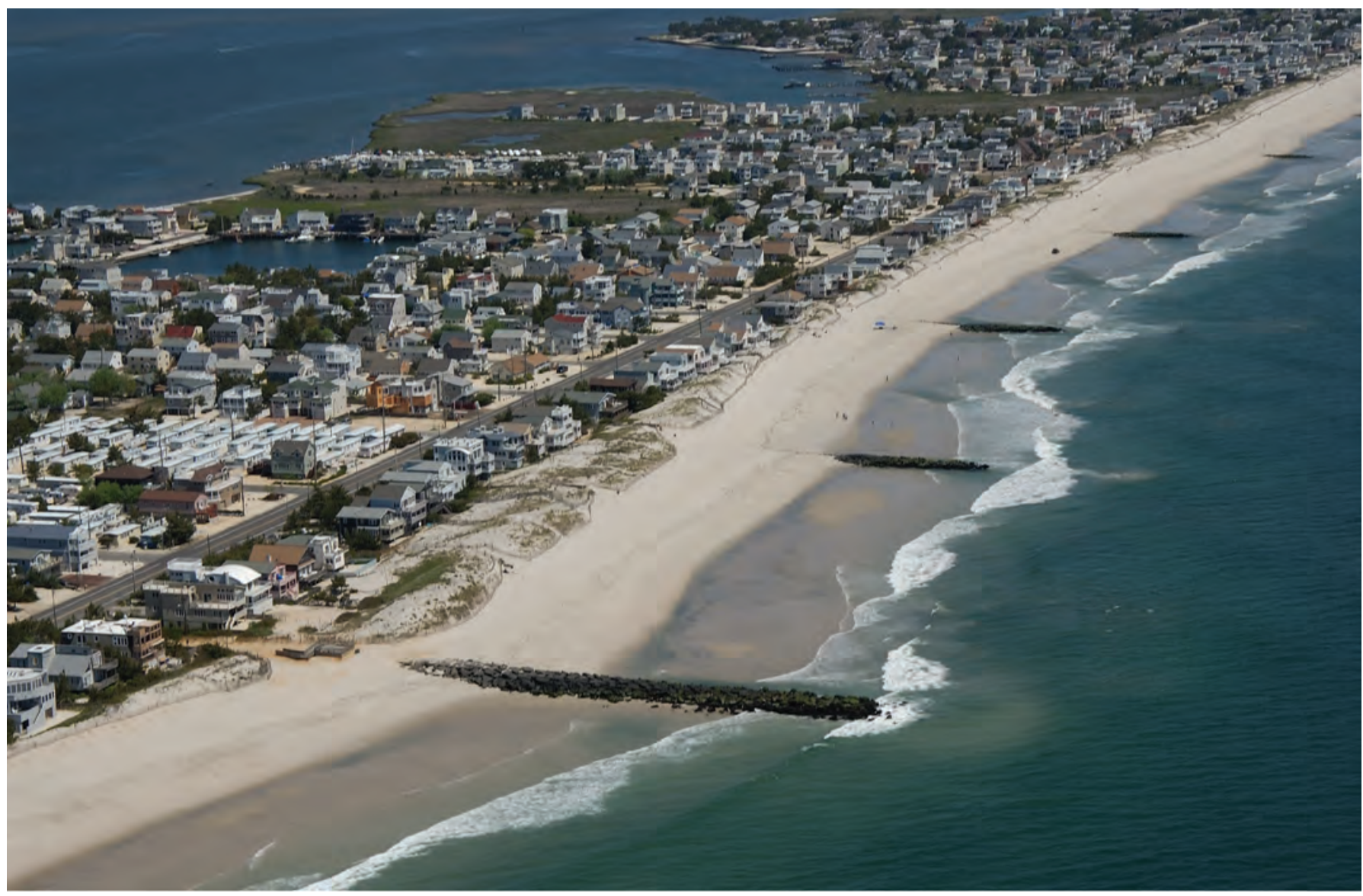

Figure 4. Oblique aerial photograph showing an extensive groin field at Beach Haven, NJ. Groin fields such as this are common in many parts of New England and the Mid-Atlantic. Photograph is taken looking to the northwest.

The New England Appalachian Province of Maine, New Hampshire, Massachusetts, and Rhode Island (Fenneman, 1946) is highly variable in terms of coastal landforms

(fig. 5), and ranges from rocky coastlines characterized by headlands and pocket beaches to mainland beaches, linear barrier islands, and coastal bluffs formed from soft glacial deposits that are fronted by narrow beaches. The Atlantic Coastal Plain is the major geomorphic province from Long Island through Virginia (but also includes Cape Cod, Nantucket, and Martha's Vineyard to the north), and consists primarily of mainland and barrier-beach coastal landforms.

Both provinces of the New England and Mid-Atlantic coasts have their origins in the early mountain-building history of the East Coast of the United States. The most recent episode was the Appalachian (sometimes called the Alleghenian) Orogeny. The Appalachian Orogeny occurred at the end of the Paleozoic Era (350 to 300 million years ago), forming the supercontinent of Pangaea (Bird and Dewey, 1970; Leitch, 1975; Rast, 1984; Walker and Coleman, 1987; Rast, 1989). Igneous and sedimentary rocks that were deposited prior to the continental collision were uplifted and metamorphosed during the mountain-building period. In the millions of years following the Appalachian Orogeny the mountains gradually eroded, burying the deformed Paleozoic bedrock beneath a thick sequence of sediment. These sediments were deposited along the shoreline of the trailing margin coast that developed as the Atlantic Ocean opened.

The geologic history of the Mid-Atlantic and New England coastal regions began to diverge substantially at the beginning of the Pleistocene Epoch, as large continental ice sheets formed and advanced over much of northern North America, including New England (Schafer and Hartshorn, 1965; Hughes and others, 1985; Dyke and others, 2002). Four major periods of glaciation directly impacted the New England coast and indirectly affected the Mid-Atlantic coast as sea level and sedimentation rates rose and fell with glacial advance and retreat. In New England, the thick layers of coastal plain sediments were eroded by the glaciers, exposing bedrock throughout much of the region, especially in the north. The irregular morphology of the rocky coast of New England is controlled largely by the fabric of the exposed bedrock and variations in exposed lithologies (Kelley, 1987; FitzGerald and others, 1994).

The glacial and sea-level history of New England is well documented (Kaye, 1964; Oldale, 1982; Uchupi, 1996), and stratigraphic evidence indicates that at the Late Wisconsinan 


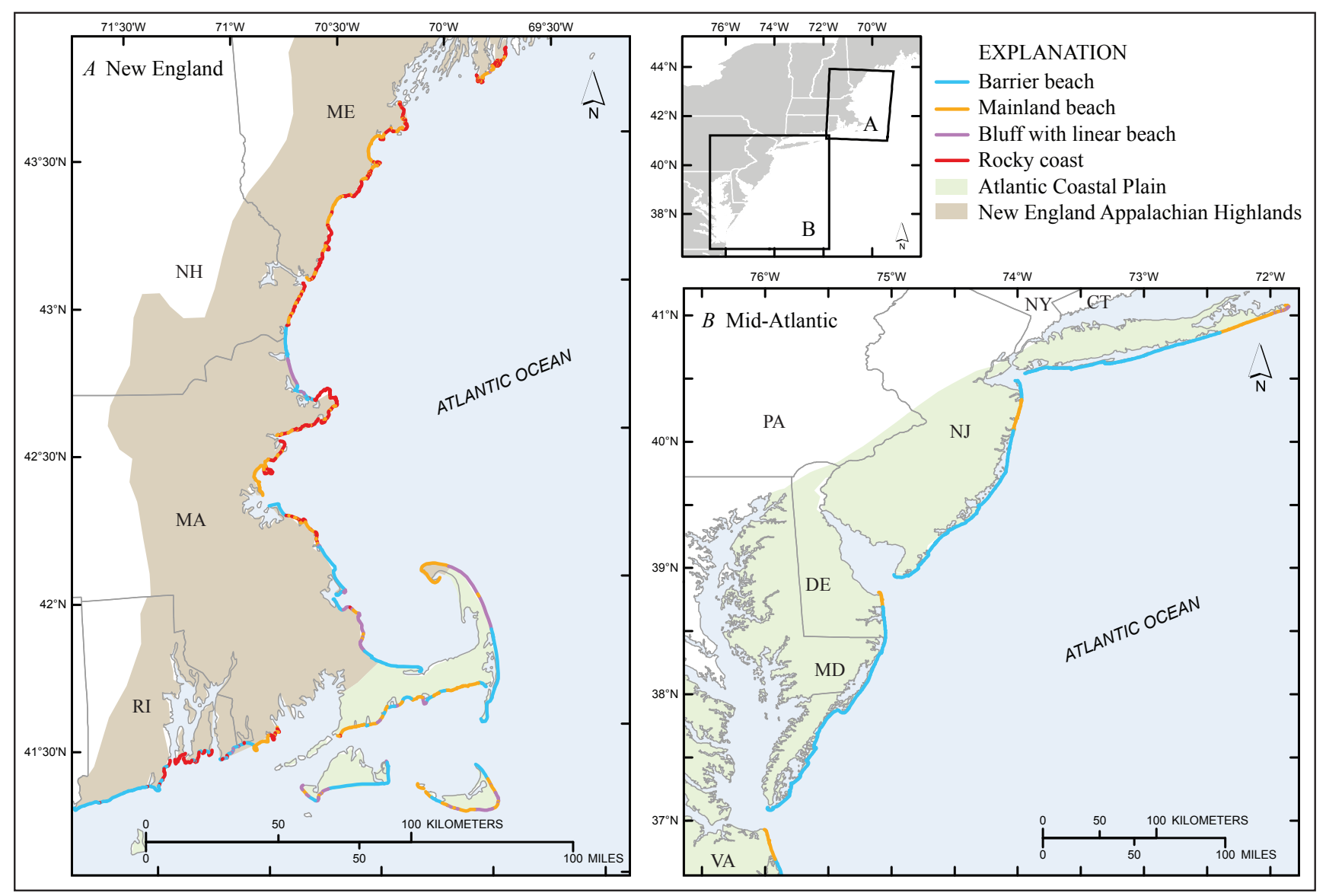

Base from Medium Resolution (1:70,000 scale, NAD 83) Digital Vector Shoreline of the coterminous United States: National Oceanic and Atmospheric Administration, 1994.

Figure 5. Map of the $(A)$ New England and (B) Mid-Atlantic coasts showing the geomorphic provinces and the general distribution of coastal landforms.

maximum (18,000 to 17,000 b.p.) the terminus of the Laurentide ice sheet extended from southern Long Island to Martha's Vineyard and Nantucket (fig. 6) (Larson, 1982; Dyke and others, 2002). This position was demarcated by a terminal moraine, the deposits of which are exposed in modern coastal bluffs at these locations. Beach development in the postglacial Holocene Epoch of New England is confined largely to pocket beaches formed from sediment trapped between rocky headlands; barrier spits; and rare, long barrier systems, such as on the outer coast of Cape Cod.

The present morphology of the Mid-Atlantic region is also related to glaciations and the rise and fall of sea level (Colquhoun and others, 1991). During low stands, rivers created large valleys that were then submerged as sea level rose. Sediments deposited on the continental shelf filled the valleys and provided the material to create the barrier-island chains that dominate the region (Swift and others, 1972; Wright, 1995). Modern rivers no longer drain to the coast; rather, they empty into the estuaries and lagoons formed behind the barrier islands, resulting in a sediment-starved coast (Wright, 1995). The modern barrier-island system of the Mid-Atlantic region formed approximately 5,000 to 6,000 years before present, when rates of sea-level rise began to slow (fig. 7). Numerous authors have explored barrier island formation and evolution throughout New England and the Mid-Atlantic (Fisher, 1968; Kraft, 1971; Swift, 1975; Leatherman, 1979; Belknap and Kraft, 1985; Leatherman, 1985; Oertel, 1985; Davis, 1994), although the majority of the analyses have been carried out in the Mid-Atlantic. The geologic framework of the MidAtlantic larely controls the locations of inlets, estuaries, and capes, which appear to be related to river and stream valleys that eroded the shelf during periods of lower sea level (Kraft, 1971; Belknap and Kraft, 1985; Demarest and Leatherman, 1985; Fletcher and others, 1990). Additionally, the geologic framework exerts control over the type and amount of sediment present. In areas of relatively higher antecedent topography, headlands formed as sea level rose provide a sediment source to the littoral system as they erode.

\section{Coastal Processes}

The New England and Mid-Atlantic coasts are stormdominated (Niederoda and others, 1985; Swift and others, 1985; Morton and Sallenger, 2003), and the active processes that shape the coast are largely the result of meteorological 


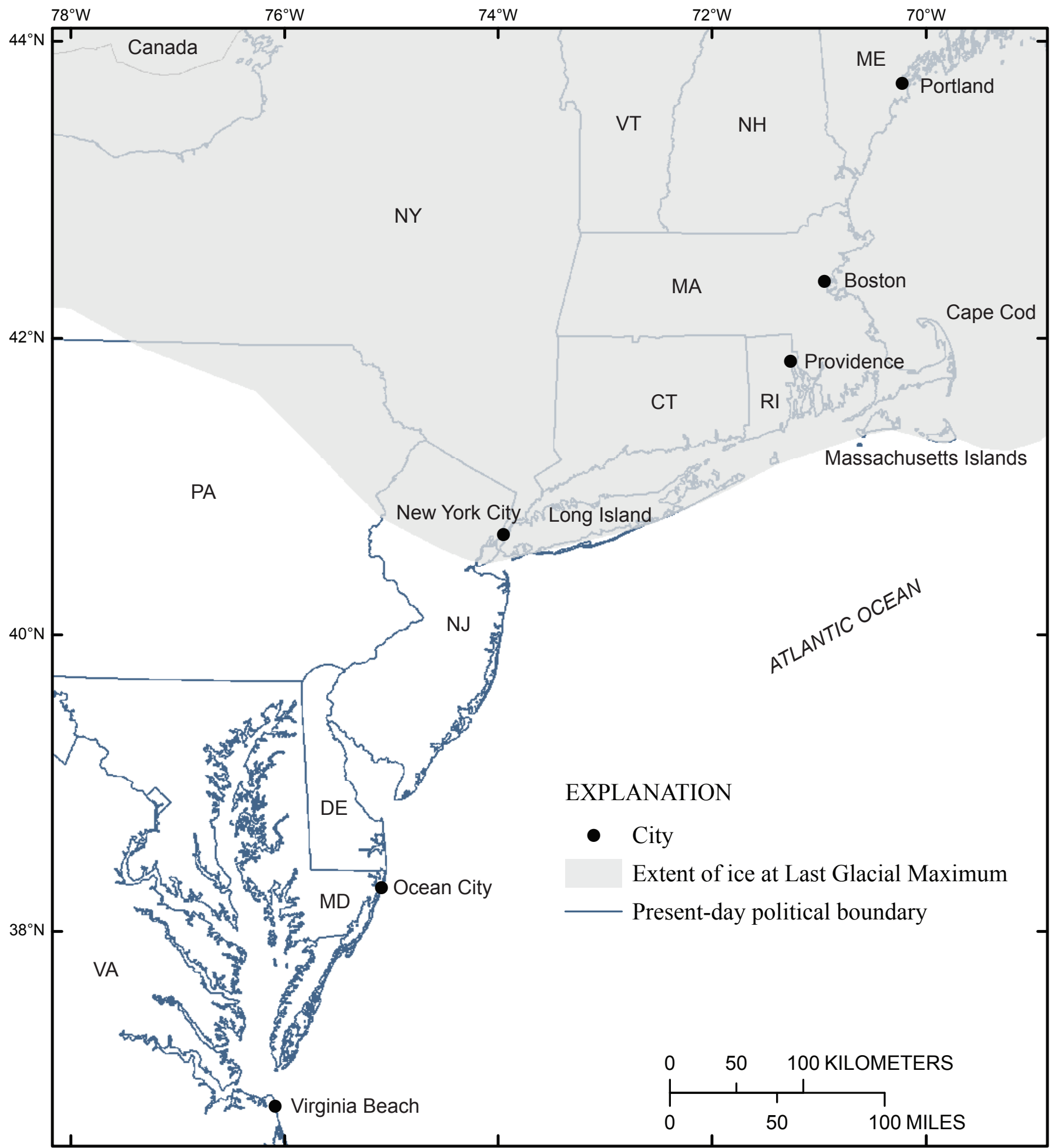

Base from Medium Resolution (1:70,000 scale, NAD 83) Digital Vector Shoreline of the coterminous United States: National Oceanic and Atmospheric Administration, 1994.

Figure 6. Map showing the Last Glacial Maximum extent of the Laurentide ice sheet in New England. 
events in the form of tropical and extratropical ("nor'easter") cyclones. Morphologies of barrier islands in New England and the Mid-Atlantic are dictated by the relative dominance of waves or tides (Hayes, 1979). The intensity, duration, and direction of winds, and, therefore, wind-driven waves, vary seasonally at a given location and spatially alongshore. Mean wave heights along the Atlantic Coast range from 0.7 to $1.3 \mathrm{~m}$ and mean wave periods from 6.4 to $7.4 \mathrm{~s}$ (U.S. Army Corps of Engineers, 2006). Wave characteristics along the New England and Mid-Atlantic coast depend on weather patterns (especially cyclonic activity), coastline orientation, storm climatology, and local bathymetry. Extratropical storms generally are less intense (lower sustained winds) than tropical storms but often impact a given portion of the coast for days as opposed to hours. Table 7 lists some of the major tropical and extratropical storms that have generated some of the largest and longest duration waves along the New England and the MidAtlantic coast over the past century. The frequency with which hurricanes have a direct impact is smaller in New England and the Mid-Atlantic than in the Southeast and Gulf coasts. However, hurricanes that never make landfall but that track, or even stall, along the Eastern Seaboard can generate large waves and storm surges that can cause severe erosion over a
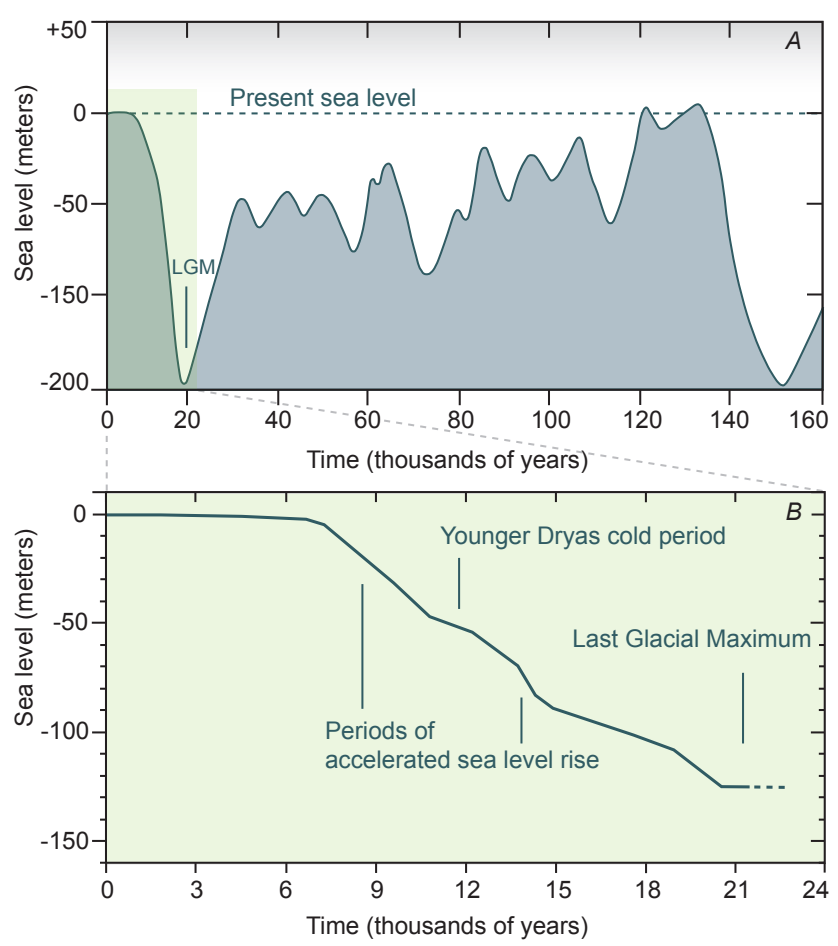

Figure 7. Graphs showing sea-level rise curves for the last $(A)$ 160,000 years and $(B) 24,000$ years on the East Coast of the United States. Modified from Chappell and Shackelton (1986). Curve since the Last Glacial Maximum is modified from Fleming and others (1998) showing the estimated change in sea level for the last 21,000 years. broad swath of the coast. The primary source of storm waves along the New England and Mid-Atlantic coast is extratropical cyclones, which can have dramatically varying intensities and durations. Extratropical storms can occur throughout the year but are most frequent during the fall and winter months.

The New England and Mid-Atlantic seaboard has a semidiurnal tidal regime of two unequal high and low tides per day. The range is controlled partly by the width and gradient of the continental shelf and related steepening of the tidal wave as it crosses the shelf (Redfield, 1958; Nummendal and others, 1977; Clarke, 1991). The highest tidal ranges are found where the shelf is wide and has a low gradient. Along the New England and Mid-Atlantic coast, the highest tidal range, $2.7 \mathrm{~m}$, is found along the coast of Maine, to the location of the widest shelf in the New England and Mid-Atlantic region (Davis and Fitzgerald, 2004). The range decreases southward as the shelf narrows. Tidal range influences beach processes and barrierisland morphologic characteristics because it determines the extent of beach exposure and inundation throughout the tidal cycle. Especially crucial to beach-erosion episodes are the timing and height of the highest tides as well as the maximum wave height and surge developed during storms.

\section{Sea-Level Rise}

Geologic evidence (recessional moraines and outwash plains) around Cape Cod indicates that ice was retreating from New England between 15,300 and 14,250 b.p. (Larson, 1982; Uchupi, 1996). Relative sea-level curves indicate that the Holocene transgression in New England, south of Boston, was steady and continuous until the sea reached present-day levels (FitzGerald and others, 1994). North of Boston, rates of sealevel rise and isostatic rebound associated with glacial retreat resulted in variable relative sea levels until 5,000 to 6,000 b.p. (Kelley and others, 1992). Sea-level rise slowed throughout New England about 3,000 to 4,000 b.p. (Oldale and O'Hara, 1980), and associated sediment deposition led to the formation of modern barrier coasts. Along the Mid-Atlantic coast, areas experienced subsidence related to isostatic rebound as the ice sheet was removed (Peltier, 1997), resulting in different rates of Holocene sea-level rise than in New England. Psuty (1986) presents data that indicate sea level in the New Jersey area rose rapidly until approximately 7,000 b.p. and then slowed from that time period on.

Modern rates of sea-level rise along the New England and Mid-Atlantic coast vary spatially and temporally (Douglas, 2001, 2005; Englehart and others, 2009), as can be seen in the tide-gage records for the past century (fig. 8). Anderson and others (1989) attribute the variability in sea-level rise in New England primarily to residual post-glacial isostatic rebound, hydrostatic loading, differential increases in tidal range, and neotectonics. Relative rates of sea-level rise are highest (3-4 $\mathrm{mm} / \mathrm{yr}$ ) in the Mid-Atlantic, where tidal ranges are high and 
Table 7. Summary of major tropical and extratropical storms impacting the New England and Mid-Atlantic coasts since 1900.

$[\mathrm{Hx}=$ hurricane category (Saffir-Simpson Hurricane Scale); TS= tropical storm, E= extratropical cyclone (“nor'easter”); storms are listed in chronological order $]$

\begin{tabular}{|c|c|c|c|c|c|}
\hline Storm & Category & Year & Date & Region & Source \\
\hline Hurricane (not named) & $\mathrm{H} 1$ & 1903 & $9 / 16$ & Mid-Atlantic & NOAA \\
\hline Hurricane (not named) & $\mathrm{H} 1$ & 1916 & $7 / 21$ & New England & NOAA \\
\hline Hurricane (not named) & $\mathrm{H} 1$ & 1936 & $9 / 19$ & New England & NOAA \\
\hline $\begin{array}{l}\text { Great New England Hurricane ("Long Island } \\
\text { Express") }\end{array}$ & H3-E & 1938 & $9 / 21$ & New England & $\begin{array}{l}\text { Morang and others, } 1999 \\
\text { NOAA }\end{array}$ \\
\hline Hurricane (not named) & $\mathrm{H} 1-\mathrm{H} 2$ & 1944 & $9 / 14-9 / 15$ & $\begin{array}{l}\text { New England } \\
\text { Mid-Atlantic }\end{array}$ & $\begin{array}{l}\text { Morang and others, } 1999 \\
\text { NOAA }\end{array}$ \\
\hline Extratropical Cyclone (not named) & $E$ & 1950 & $11 / 25$ & Mid-Atlantic & Morang and others, 1999 \\
\hline Hurricane Carol & $\mathrm{H} 2$ & 1954 & $8 / 31$ & $\begin{array}{l}\text { New England } \\
\text { Mid-Atlantic }\end{array}$ & $\begin{array}{l}\text { Morang and others, } 1999 \\
\text { NOAA }\end{array}$ \\
\hline Hurricane Edna & $\mathrm{H} 1-\mathrm{H} 2$ & 1954 & $9 / 11$ & New England & NOAA \\
\hline Hurricane Donna & $\mathrm{H} 1-\mathrm{H} 2$ & 1960 & $9 / 12-9 / 13$ & $\begin{array}{l}\text { New England } \\
\text { Mid-Atlantic }\end{array}$ & NOAA \\
\hline Ash Wednesday Storm & $E$ & 1962 & $3 / 6-3 / 8$ & Mid-Atlantic & $\begin{array}{l}\text { Davis and Dolan, 1993; } \\
\text { Morang and others, } 1999\end{array}$ \\
\hline Hurricane Belle & $\mathrm{H} 1-\mathrm{H} 2$ & 1976 & $8 / 9-8 / 10$ & Mid-Atlantic & NOAA \\
\hline Blizzard of 1978 & $E$ & 1978 & $2 / 5-2 / 7$ & New England & Glass and others, 1979 \\
\hline Hurricane Gloria & $\mathrm{H} 1-\mathrm{H} 2$ & 1985 & $9 / 27$ & Mid-Atlantic & NOAA \\
\hline Extratropical Cyclone (not named) & $E$ & 1989 & $3 / 7-3 / 11$ & Mid-Atlantic & Dolan and others, 1990 \\
\hline Hurricane Bob & $\mathrm{H} 2$ & 1991 & $8 / 19$ & New England & NOAA \\
\hline $\begin{array}{l}\text { Halloween nor'easter or, "All Hallow's Eve" } \\
\text { storm, or, Perfect Storm }\end{array}$ & E & 1991 & $10 / 28-10 / 31$ & $\begin{array}{l}\text { New England } \\
\text { Mid-Atlantic }\end{array}$ & $\begin{array}{l}\text { Davis and Dolan, 1992; } \\
\text { Morang and others, } 1999\end{array}$ \\
\hline Extratropical Cyclone (not named) & E & 1992 & $12 / 11-12 / 14$ & Mid-Atlantic & Morang and others, 1999 \\
\hline "Storm of the Century" & $E$ & 1993 & $3 / 12-3 / 13$ & $\begin{array}{l}\text { New England } \\
\text { Mid-Atlantic }\end{array}$ & Davis and Dolan, 1993 \\
\hline Hurricane Floyd & H1-TS-E & 1999 & $9 / 16-9 / 17$ & $\begin{array}{l}\text { New England } \\
\text { Mid-Atlantic }\end{array}$ & NOAA \\
\hline Patriots Day Storm & $E$ & 2007 & $4 / 15-4 / 18$ & New England & Marrone, 2008 \\
\hline "Nor'lda" & $E$ & 2009 & $11 / 11-11 / 15$ & Mid-Atlantic & USGS \\
\hline
\end{tabular}

coastal subsidence is occurring, especially in New Jersey and Delaware. In Maine, a low tidal range coupled with residual isostatic rebound results in the lowest relative rate of sea-level rise $(1.8 \mathrm{~mm} / \mathrm{yr})$ in New England and the Mid-Atlantic.

\section{Sediment Sources and Transport}

The primary sources of coastal sediment for the New England and Mid-Atlantic region are updrift eroding coasts and offshore riverine and glacial deposits (Niederoda and others, 1985; Swift and others, 1985). Rivers are not considered a primary source of sediment within the modern coastal system, as little modern river sediment reaches the present-day coast (Meade and Emery, 1971; Wright, 1995). An exception to this is riverine input along the coast of Maine, where large rivers provide sediment to the coast (Fenster and FitzGerald, 1996) and smaller systems deliver sediment to form pocket beaches between headlands, and small barrier spits in low-lying areas.

Along the more elongate barrier islands of the MidAtlantic, the coastline is relatively straight and wave approach is oblique, driving net sediment transport in a specific direction (that is westward along the Long Island coast, and, in general, south along the New Jersey and Delmarva coasts). Along the more irregular, crenulated New England coast, sediment transport is confined between headlands or embayments. Little exchange of material occurs in or out of the embayments and, 


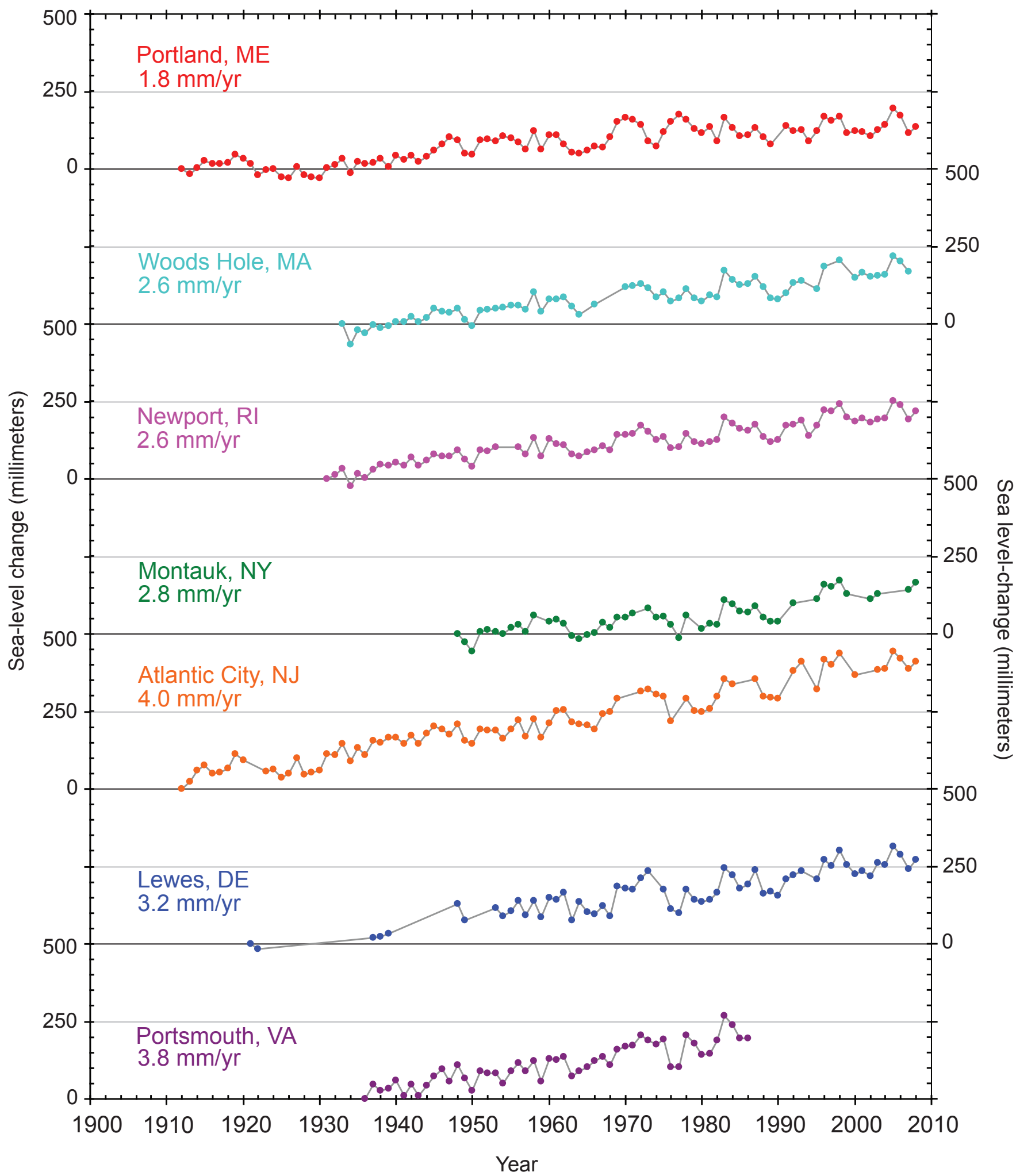

Figure 8. Graphs showing long-term (100-year) trends in average annual sea level at selected tide gages in New England and the Mid-Atlantic. Data are from the Permanent Service for Mean Sea Level (PSMSL) and can be downloaded from www.psmsl. org/data/obtaining/. (mm/yr, millimeters per year) 
as a result, there is no net longshore movement of material. Along less crenulated portions of the New England coast, longshore-transport directions are highly variable (Jensen, 1983; FitzGerald and others, 1994) and are driven by the direction of wave approach, which is locally influenced by the presence of shoals, islands, and headlands and by coastal orientation.

\section{Landforms of the New England and Mid-Atlantic Coasts}

The New England and Mid-Atlantic region is composed of four general coastal geomorphologic types: rocky coasts; bluffs with narrow fronting beaches; mainland beaches, which are considered to be beaches connected to the mainland, whether fronting bluffs, dunes, or extensive marshes; and barrier beaches (which for this report include both islands and spits). Figure 5 shows the regional distribution of these features and highlights the diversity of landform type along the New England and Mid-Atlantic coast. Long, linear barrier beaches, with associated lagoons, inlets, and spits, are most common in the Mid-Atlantic, whereas the rocky coasts and the majority of the bluffed coasts are in New England. Table 8 provides the relative distribution of shore type in New England and the Mid-Atlantic, which is dominated by linear or mainland beaches ( 78 percent), followed by rocky coasts (15 percent) and bluffs with fronting beaches (7 percent). Photographic examples of each type of coastal geomorphology are shown in figure 9 and a schematic diagram of different coastal features found along the New England and Mid-Atlantic coasts is shown in figure 10.

\section{Coastal Landforms of New England}

Coastal landforms of New England (for this report, defined as extending from central Maine through Rhode Island) are paraglacial (Forbes and Syvitski, 1994) and include fjords, rocky headlands, periglacial deposits such as moraines and drumlins, and sand and gravel beaches derived from outwash and other glacial deposits. Glaciogenic sediment, which can range widely in size, is dominant in paraglacial coasts. As a result, mixed-sediment beaches derived from these materials are composed of a wide range of sediment sizes, and are commonly composed of sand and cobble- to boulder-sized material.

Barrier beaches in New England are typically small and discontinuous as a result of localized and limited sediment sources and partitioning of the coast by headlands (FitzGerald and others, 1994; van Heteren and others, 1998). Small pocket beaches, bound by rocky headlands, occur in areas that lack a substantial sediment source and sufficient lowland area to migrate or grow as a barrier spit. Beaches in New England are primarily transgressive, with barrier-spit beaches exhibiting evidence of overwash and peat exposure in the intertidal zone. With no room to transgress, pocket beaches tend to be composed of lag sediments dominated by larger sizes (gravel and larger), as sand tends to be lost from the system during large storms.

Rocky and bluffed portions of the coast comprise outcroppings of crystalline bedrock and glacial deposits, respectively. Rocky areas of the coastline form headlands that protect and isolate pocket beaches and are relatively stable coastal features. Coastal bluffs in New England and northeastern Long Island are the result of the erosion of higher relief landforms, such as drumlins and moraines, during thousands of years of sea-level rise. Eroded bluff sediment forms narrow beaches in front of eroding bluffs. Coarser material may form a lag deposit that remains after finer sediments are transported away, marking the approximate former position of the bluff (Kelley, 2004).

\section{Coastal Landforms of the Mid-Atlantic}

The most common coastal landforms in the Mid-Atlantic are barrier islands and barrier spits, with fewer occurrences of mainland beaches (table 8). A small stretch of high glacial bluffs with fronting beaches occurs at the eastern terminus of Long Island. The shape and morphology of barrier beaches are a function of the wave energy and direction, and tidal range (Hayes, 1979). Long, linear barrier beaches form in microtidal environments where storm processes, such as overwash and breaching, dominate. Inlets are widely spaced along coast and have small ebb-tide deltas compared to flood-tide deltas. The relatively low tidal flow in microtidal settings is not sufficiently strong to maintain an opening if an island breaches during a storm. Flood currents through established inlets tend to be much stronger than return (ebb) flows.

Short, wide barrier islands are also common in the MidAtlantic region and are associated with a mixed-energy environment in which both storm processes and a relatively large tidal range work together to shape the islands and maintain the inlets (Hayes, 1979). Stronger tidal currents develop within island breaches, allowing storm-created channels to remain open. Large ebb deltas commonly form on the seaward side of mixed-energy barriers. The ebb shoals can influence patterns of wave approach, leading to higher rates of erosion adjacent to the inlets and transportation and deposition of sediment along the downcoast portion of the island. As a result, the islands narrow on one end and widen on the other, forming what is referred to as a "drumstick" barrier (Hayes, 1979; Davis, 1994).

\section{Estuaries and Lagoons in the New England and Mid-Atlantic Areas}

According to a classification by Healy and Kirk (1982), there are four types of estuaries, including (1) fiords, which are flooded valleys of glacial origin; (2) drowned river valleys; (3) 
barrier-enclosed estuarine lagoons composed of barrier islands and spits that enclose or partially enclose a shallow lagoon; and (4) structurally induced estuaries. These categories are not independent or mutually exclusive; rivers and glaciers may follow structurally weak zones that are subsequently flooded as sea level rises. Most of the large estuaries in New England and the Mid-Atlantic are fiords and drowned river valleys, respectively, and are perpendicular or at a high angle to the shoreline. Some of the larger estuaries include Buzzards Bay, Narragansett Bay, Delaware Bay, and Chesapeake Bay. Narragansett Bay is the largest estuary in New England and Chesapeake Bay is the largest estuary in the United States.

Lagoon systems occur throughout New England and the Mid-Atlantic coast. Some of the larger systems include Great South Bay, Barnegat Bay, and Chincoteague Bay. Many of the narrow coastal lagoons, especially in the Mid-Atlantic, are formed from flooded smaller rivers and streams that flowed parallel to shore.
Estuary and lagoon environments are important coastal ecosystems and occur along much of the Atlantic Seaboard. They serve as sediment sinks, preventing material from reaching the Atlantic littoral system. The accumulation of continental sediments in estuaries provides the substrate upon which extensive marsh systems develop. Estuary and lagoon shorelines are not evaluated in this report because of the focus on open-ocean coasts.

\section{History of Infrastructure Development}

The first European to explore the coast of New England and the Mid-Atlantic is widely held to be Italian explorer Giovanni da Verrazano, in 1524. The earliest permanent settlement was Jamestown, VA, in 1607. In 1609, Henry
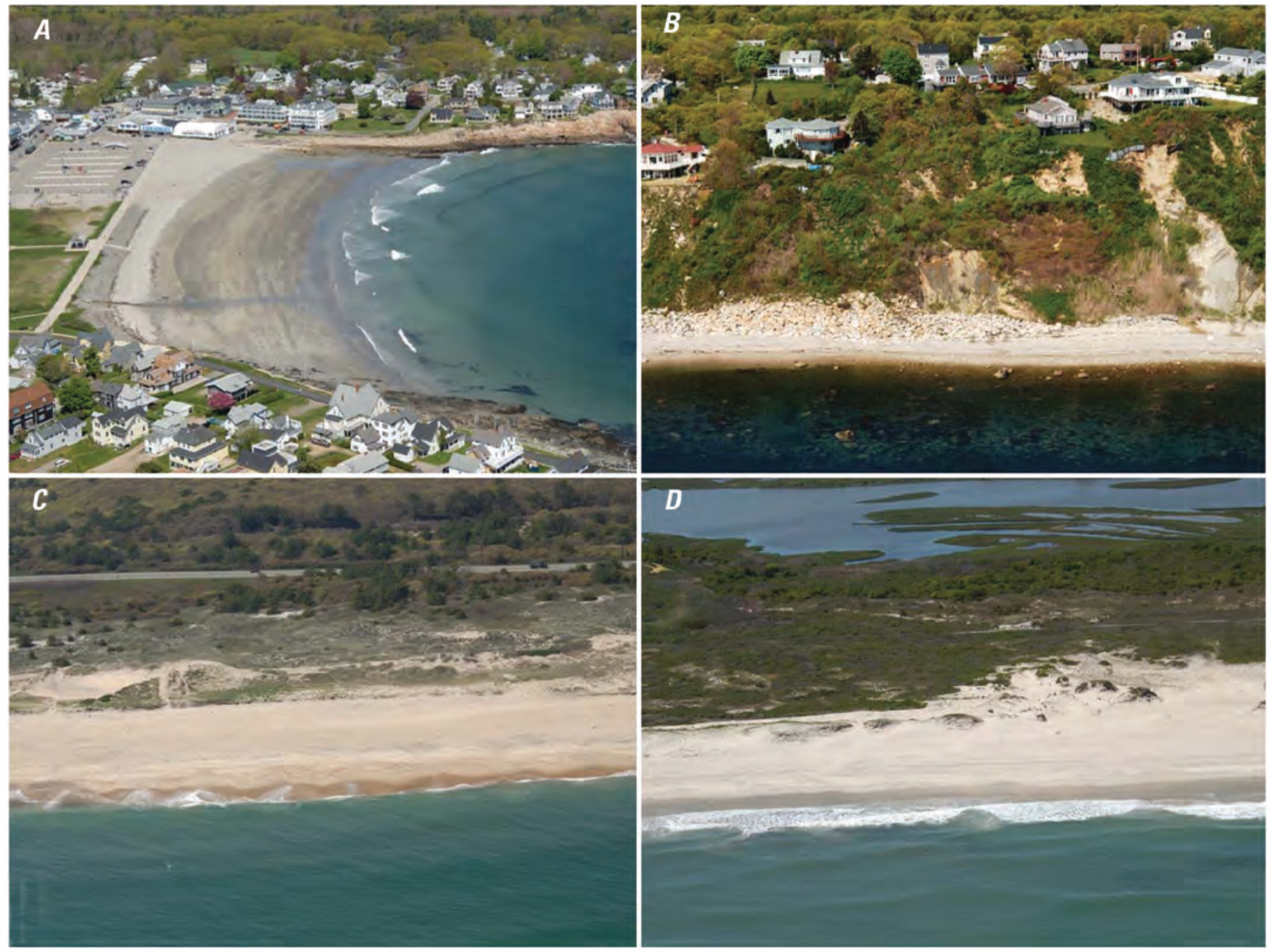

Figure 9. Oblique aerial photographs showing the various geomorphic shore types along the New England and Mid-Atlantic coasts: $(A)$ pocket beach, Cape Neddick, Maine; $(B)$ bluff with linear beach, Colony Beach, Massachusetts; $(C)$ mainland beach, Hither Hills Beach, New York; and $(D)$ barrier island beach, Assateague Island, Maryland. 
Hudson, representing Dutch interests, landed on Manhattan Island. Shortly afterwards, the Dutch West Indies Company sent the first permanent European settlers to Manhattan Island, on which the proto-New York town of New Amsterdam was founded in 1624. After multiple skirmishes with the English, the Dutch surrendered in 1664 and the town was renamed New York. Settlements established concurrently with the founding history of New York were established up and down the New England and Mid-Atlantic coast, which rapidly became a thriving region for ports and trading.

According to the U.S. Census Bureau, the total population of the original Colonies in the New England and MidAtlantic region was 4,700 in 1630 . By 1780, this number had grown to more than 1.6 million. Exponential population growth prompted the building of coastal fortifications, including military installations, and the emplacement of structures to protect harbors and navigation channels. Most of the coastal alteration, however, was restricted to the large population centers. The coast outside these areas was sparsely, if at all, populated.

The coast did not become a vacation destination until the mid-1800s, when railroads connecting the interior lands to the coast were constructed (Houston, 2003). The first of these connected Camden to Atlantic City, NJ. As automobiles became common and more roads were constructed, beaches became an increasingly popular tourist destination.

Coastal structures are ubiquitous along many portions of the New England and Mid-Atlantic coastline, from groin fields and seawalls built to protect individual buildings or communities to jetties and breakwaters built to stabilize inlets and harbors and to keep navigation channels open. The longest period of beach development began following World War II
(Pilkey and Dixon, 1996) and has continued to the present day. It is estimated from a USGS overflight of the coast in 2009 that approximately 33 percent of the New England and MidAtlantic coast exhibits some type of coastal structure (unpublished data available at the U.S. Geological Survey, Woods Hole, MA). The various structures have interrupted sedimenttransport processes and, in the case of seawalls, resulted in the loss of beaches in many areas. To counter the effects of the structures, as well as damage from storms, beach nourishment projects are frequently undertaken. As a result, there are very few locales in New England and the Mid-Atlantic where coastal processes proceed unimpeded.

Although many areas of the New England and MidAtlantic coast are heavily developed or urbanized, the Federal government began setting aside coastal lands as national parks and wildlife refuges. In 1961, the first national park in the New England and Mid-Atlantic region, Cape Cod National Seashore, was established. Presently, long stretches of the New England and Mid-Atlantic coast are public lands, including Fire Island National Seashore, Gateway National Recreation Area, and Assateague Island National Seashore. Although the National Park Service attempts to allow natural processes to occur without interference, the extensive development within or adjacent to parks presents management challenges.

\section{Historical Shoreline Change Analysis}

This section presents the results of the New England and Mid-Atlantic sandy shoreline change analysis and discusses,

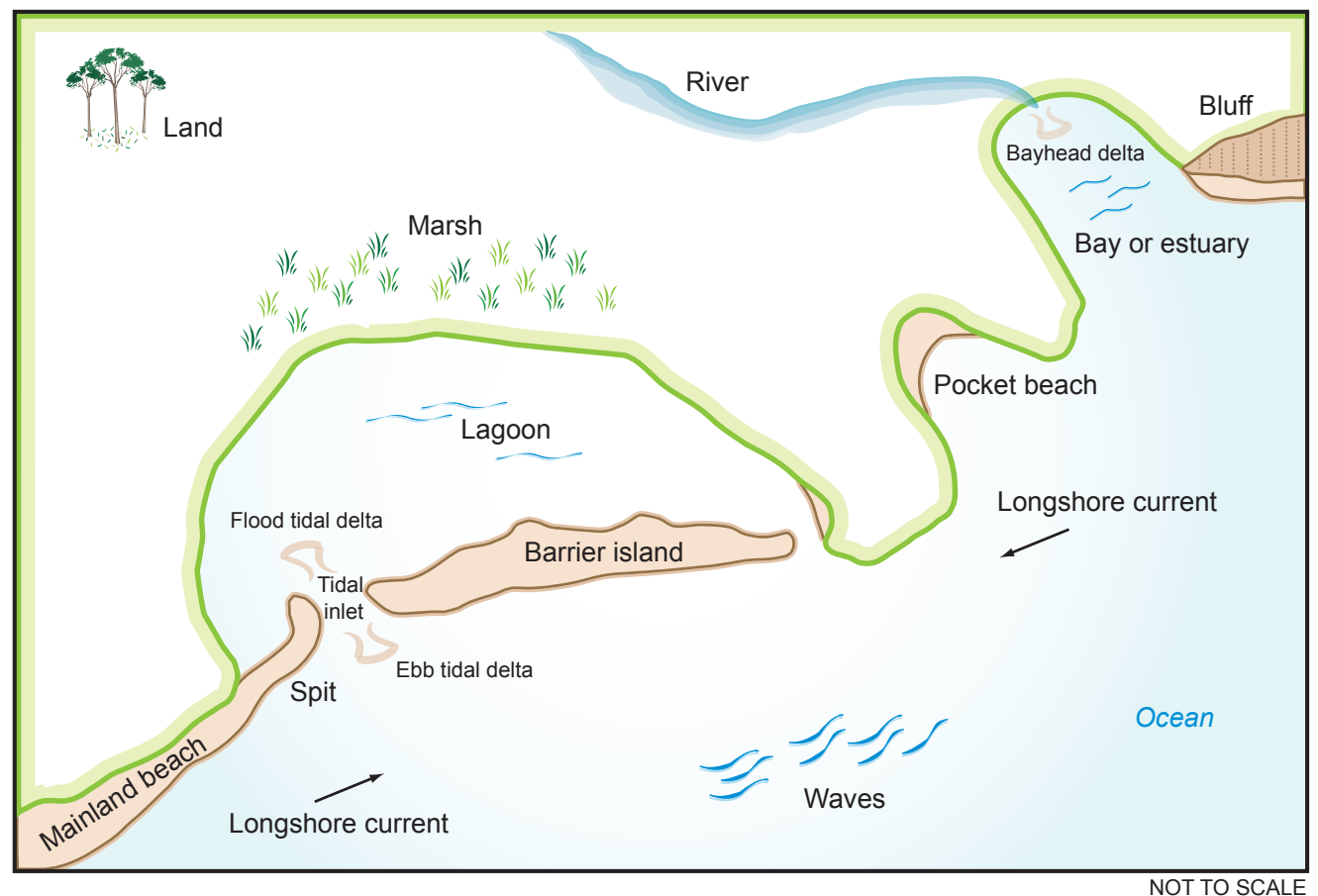

Figure 10. Schematic diagram showing common coastal landforms of New England and the Mid-Atlantic. 
Table 8. Relative distribution of geomorphic shore-types along the New England and Mid-Atlantic coasts.

[km, kilometer]

\begin{tabular}{lcc}
\hline Shore-type & Length $(\mathbf{k m})$ & $\begin{array}{c}\text { Percent of total } \\
\text { length }\end{array}$ \\
\hline Rocky coast & 211 & 15 \\
Bluffs with linear beaches & 104 & 7 \\
Mainland beaches & 340 & 23 \\
Barrier beaches & 805 & 55 \\
Total length of coast & 1460 & 100 \\
Structures present & 384 & 26 \\
\hline
\end{tabular}

where possible, the potential effects of engineering structures and beach nourishment projects on the rates of shoreline change. The New England and Mid-Atlantic coast is subdivided into 10 regions (fig. 1), which are based broadly on coastal geomorphology and the orientation of the coast. Tables $9 \mathrm{a}$ and $9 \mathrm{~b}$ summarize both long-term and short-term average rates of shoreline change within each region. Additionally, tables $10 \mathrm{a}$ and $10 \mathrm{~b}$ present the maximum and minimum erosion and accretion rates for each region in New England and the Mid-Atlantic.

The descriptions of shoreline change include discussion of human-induced changes. Many of the substantial erosion/ accretion trends and (or) reversals in trend are related to human intervention within the natural coastal system. The New England and Mid-Atlantic shorelines are thought to be eroding primarily because of sea-level rise and climatic changes, and as a consequence of human activities that disrupt the natural sediment supply. For each region, the level of development is described as sparse, moderate, dense, heavy, or urban. These categories are subjective but, for the purposes of this report, are broadly defined as follows:

Sparse - widely spaced, single-family homes not clustered in communities; little to no tourist infrastructure or commercial development.

Moderate - predominantly single-family homes, possibly concentrated in communities; some open space between communities; some tourist infrastructure such as parking lots and bath houses; limited commercial development. Dense - single-family homes and hotels/apartments of only several stories; nearly continuous communities; some tourist infrastructure and commercial development. Heavy - predominantly multi-storied hotels and condominium complexes continuous alongshore; tourist infrastructure such as boardwalks and parking lots; substantial commercial development.

Urban - multi-storied hotels, condominium complexes and apartment buildings continuous alongshore; extensive commercial and some industrial infrastructure; limited tourist infrastructure.
In the discussions below, rates are referenced from tables $9 a$ and $9 b$ where shoreline change rates are presented as the region-averaged net rate for the long-term (1800s-1997/2000) and short-term (1960-70s-1997/2000) analyses. The regionaveraged net change rates are the average of both negative (erosional) and positive (accretional) rates; hence, the use of the term net to distinguish this rate from the erosion-only rates that are also presented in tables 9a and 9b. Additionally, we present the percent of the measured coastline that is eroding at rates faster than -1 and $-3 \mathrm{~m} / \mathrm{yr}$. For the rates reported herein, erosional trends are presented as negative values and accretional trends are presented as positive values. Although shoreline change rates in some areas are relatively low or accretional, many beaches in the New England and Mid-Atlantic are narrow and even a small amount of local erosion may present serious hazards to the coastal resources and community infrastructure in a given area.

Errors and uncertainty values for each region are included in tables $9 \mathrm{a}$ and $9 \mathrm{~b}$. A statistical t-test was performed to determine whether the long-term and short-term rates were significantly different from one another at the 90-percent confidence interval. The t-test results indicate that the difference between long-term and short-term rates is statistically significant in all regions. In the Delmarva North and Delmarva South/Southern Virginia regions, the short-term rates of change became more erosional. In the remaining eight analysis regions, the average shoreline change rates either did not change over time or were more accretional in the short term than in the long term. This trend is likely attributable to increases in nourishment projects within most regions of New England and Mid-Atlantic coasts during the more recent period ( $25-30 \mathrm{yr})$. Tables $10 \mathrm{a}$ and $10 \mathrm{~b}$ list the maximum erosion and accretion rates for each region for both the long and short term.

The average net rate of long-term shoreline change for New England was - $-0.4 \mathrm{~m} / \mathrm{yr}$ and for the Mid-Atlantic was - 0.6 $\mathrm{m} / \mathrm{yr}$, an erosional trend. These rates are based on shoreline change rates averaged from 19,784 individual transects, of which 65 percent were eroding. The analysis showed that three regions in New England and the Mid-Atlantic experienced long-term positive net shoreline change: New England North $(0.1 \mathrm{~m} / \mathrm{yr})$, Long Island $(0.08 \mathrm{~m} / \mathrm{yr})$, and New Jersey South $(0.8 \mathrm{~m} / \mathrm{yr})$ (table $9 \mathrm{a})$. The highest negative (erosional) region-averaged net rate was measured in the Delmarva South/ Southern Virginia region (-3.7 m/yr). Overall, New England had a slightly less erosional net long-term shoreline change than the Mid-Atlantic (-0.4 m/yr and $-0.6 \mathrm{~m} / \mathrm{yr}$, respectively). The percentage of coast eroding in the long term in New England was greater than in the Mid-Atlantic (71 and 67 percent, respectively). However, a larger percentage of the MidAtlantic coast was eroding at higher rates in the long term: 18 percent of the New England coast was eroding at rates greater than $-1 \mathrm{~m} / \mathrm{yr}$, compared to 26 percent of the Mid-Atlantic coast. In New England, only 3 percent of the coast was found to be eroding at rates greater than $-3 \mathrm{~m} / \mathrm{yr}$ in the long term, whereas 11 percent of the Mid-Atlantic coast was eroding at rates greater than $-3 \mathrm{~m} / \mathrm{yr}$. 
Table 9a. Average long-term shoreline change rates for the New England and Mid-Atlantic (NEMA) coasts. $[\mathrm{m} / \mathrm{yr}$, meters per year]

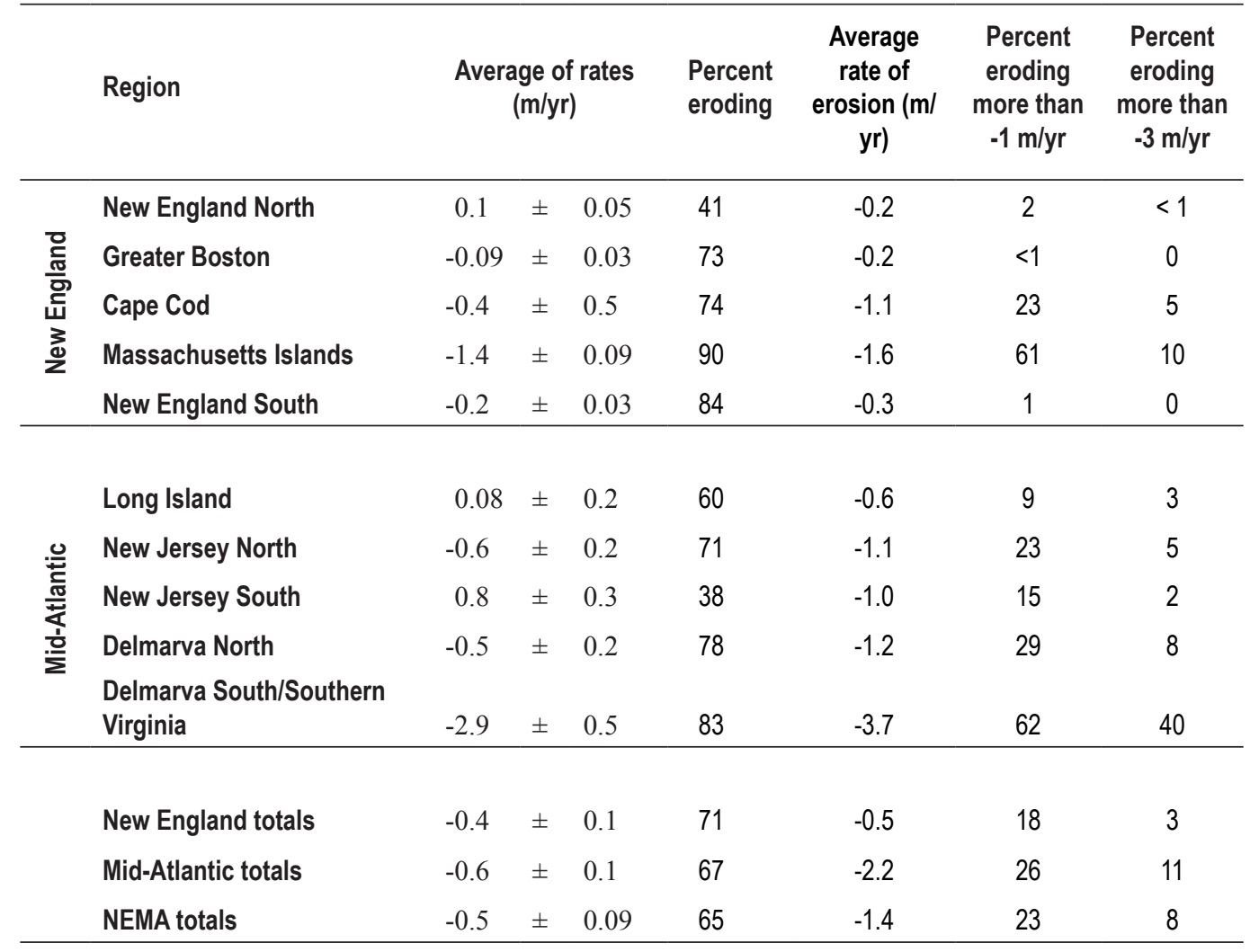

Table 9b. Average short-term shoreline change rates for the New England and Mid-Atlantic (NEMA) coasts. [m/yr, meters per year]

\begin{tabular}{|c|c|c|c|c|c|c|c|c|}
\hline & Region & Averas & e of & tes (m/yr) & $\begin{array}{l}\text { Percent } \\
\text { eroding }\end{array}$ & $\begin{array}{c}\text { Average } \\
\text { rate of } \\
\text { erosion }\end{array}$ & $\begin{array}{l}\text { Percent } \\
\text { eroding } \\
\text { more than }\end{array}$ & $\begin{array}{c}\text { Percent } \\
\text { eroding } \\
\text { more than }\end{array}$ \\
\hline \multirow{5}{*}{$\begin{array}{l}\text { 을 } \\
\frac{\overline{0}}{\bar{D}} \\
\text { W } \\
\frac{3}{2}\end{array}$} & New England North & -0.4 & \pm & 0.1 & 75 & -0.9 & 20 & 2 \\
\hline & Greater Boston & -0.1 & \pm & 0.06 & 68 & -0.6 & 11 & $<1$ \\
\hline & Cape Cod & 0.3 & \pm & 0.09 & 73 & -2.9 & 42 & 16 \\
\hline & MA Islands & -0.8 & \pm & 0.1 & 74 & -1.7 & 43 & 10 \\
\hline & New England South & -0.09 & \pm & 0.1 & 62 & -0.4 & 2 & $<1$ \\
\hline \multirow{8}{*}{ 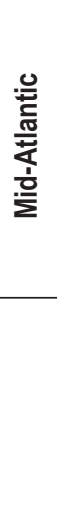 } & Long Island & 0.8 & \pm & 0.09 & 36 & -1.0 & 15 & 1 \\
\hline & New Jersey North & 0.5 & \pm & 0.06 & 58 & -0.9 & 3 & 1 \\
\hline & New Jersey South & 0.2 & \pm & 0.1 & 48 & -2.2 & 28 & 10 \\
\hline & Delmarva North Delmarva South/ & -0.8 & \pm & 0.04 & 71 & -2.1 & 45 & 16 \\
\hline & Southern Virginia & -2.7 & \pm & 0.1 & 66 & -5.6 & 50 & 35 \\
\hline & New England total & -0.2 & \pm & 0.09 & 70 & -1.5 & 27 & 7 \\
\hline & Mid-Atlantic total & -0.3 & \pm & 0.1 & 54 & -2.5 & 27 & 12 \\
\hline & NEMA total & -0.3 & \pm & 0.1 & 60 & -2.1 & 27 & 10 \\
\hline
\end{tabular}


Table 10a. Maximum shoreline change rates: New England coast.

[m/yr, meters per year; max., maximum]

\begin{tabular}{|c|c|c|c|c|}
\hline Region & $\begin{array}{l}\text { Long-term } \\
\text { rate }(\mathrm{m} / \mathrm{yr})\end{array}$ & Location & $\begin{array}{l}\text { Short-term } \\
\text { rate }(\mathrm{m} / \mathrm{yr})\end{array}$ & Location \\
\hline \multicolumn{5}{|c|}{ New England North } \\
\hline Max. erosion & -2.5 & Morse River, Phippsburg, ME & -4.9 & Castle Neck Beach, MA \\
\hline Max. accretion & 3.5 & Morse River, Phippsburg, ME & 9.4 & Castle Neck Beach, MA \\
\hline \multicolumn{5}{|l|}{ Greater Boston } \\
\hline Max. erosion & -2.1 & New Inlet, at Herring River & -4.8 & North Situate Beach \\
\hline Max. accretion & 2.9 & West side of Cape Cod Canal & 8.0 & Sandy Neck \\
\hline \multicolumn{5}{|l|}{ Cape Cod } \\
\hline Max. erosion & -8.0 & Monomoy Island & -21.6 & Chatham Inlet \\
\hline Max. accretion & 8.1 & Monomoy Island & 59.3 & South Beach \\
\hline \multicolumn{5}{|l|}{ MA Islands } \\
\hline Max. erosion & -4.4 & South Beach, Martha's Vineyard & -11.7 & Tuckernuck Island, Nantucke \\
\hline Max. accretion & 4.4 & Esther Island, Nantucket & 29.7 & Tuckernuck Island, Nantucke \\
\hline \multicolumn{5}{|c|}{ New England South } \\
\hline Max. erosion & -1.4 & East Matunuck State Beach, RI & -1.9 & $\begin{array}{l}\text { Horseneck Point, MA at the } \\
\text { entrance to Westport Harbor }\end{array}$ \\
\hline Max. accretion & 1.1 & West side (jettied) inlet to Pt. Judith Pond, RI & 1.9 & Card Pond, Matunuck, RI \\
\hline
\end{tabular}

Table 10b. Maximum shoreline change rates: Mid-Atlantic coast. [m/yr, meters per year; max., maximum]

\begin{tabular}{|c|c|c|c|c|}
\hline Region & $\begin{array}{l}\text { Long-term } \\
\text { rate }(\mathrm{m} / \mathrm{yr})\end{array}$ & Location & $\begin{array}{l}\text { Short-term } \\
\text { rate }(\mathrm{m} / \mathrm{yr})\end{array}$ & Location \\
\hline \multicolumn{5}{|l|}{ Long Island } \\
\hline Max. erosion & -4.9 & Western end of Gilgo Beach & -4.2 & Fire Island, by William Floyd Pkwy cupola \\
\hline Max. accretion & 20.2 & Western end of Jones Beach & 19.6 & Eastern end of Gilgo Beach \\
\hline \multicolumn{5}{|c|}{ New Jersey North } \\
\hline Max. erosion & -8.6 & South end of Long Beach Island & -6.1 & South end of Long Beach Island \\
\hline Max. accretion & 5.9 & Sandy Hook & 33.6 & Barnegat Lighthouse State Park \\
\hline \multicolumn{5}{|c|}{ New Jersey South } \\
\hline Max. erosion & -4.3 & $\begin{array}{l}\text { Cape May, west of Beach Ave } \\
\text { and series of groins }\end{array}$ & -19.3 & $\begin{array}{l}\text { North of Brigantine Island, adjacent to } \\
\text { Brigantine Inlet }\end{array}$ \\
\hline Max. accretion & 15.4 & $\begin{array}{l}\text { North end Little Beach island, } \\
\text { adjacent to Little Egg Inlet }\end{array}$ & 10.3 & Spit on south side of Corson Inlet \\
\hline \multicolumn{5}{|l|}{ Delmarva North } \\
\hline Max. erosion & -6.2 & North end of Assateague & -9.2 & South end of Assateague \\
\hline Max. accretion & 21.5 & South end of Assateague & 40.3 & South end of Assateague \\
\hline \multicolumn{5}{|l|}{ Delmarva South / } \\
\hline \multicolumn{5}{|l|}{ Southern Virginia } \\
\hline Max. erosion & -18.5 & South end of Hog Island & -40.3 & South end of Parramore Island \\
\hline Max. accretion & 10.0 & $\begin{array}{l}\text { Eastern side of Fishermans } \\
\text { Island }\end{array}$ & 50.6 & North end of Hog Island \\
\hline
\end{tabular}


The average net rate of short-term change for New England and the Mid-Atlantic was $-0.3 \mathrm{~m} / \mathrm{yr}$ based on 17,339 transects, 60 percent of which were eroding. Negative (erosional) net short-term shoreline change was measured in 6 of the 10 regions. The percentage of coast eroding in the short term was higher in New England (70 percent) than in the Mid-Atlantic (54 percent). The percentage of coastline eroding at short-term rates greater than $-1.0 \mathrm{~m} / \mathrm{yr}$ was the same in New England and the Mid-Atlantic (27 percent). However, more of the MidAtlantic coast was eroding at faster rates (>-3.0 m/yr).

\section{New England: Maine to Rhode Island}

The shoreline change analysis of New England covers the coast from Popham Beach, ME, through Rhode Island, a distance of approximately $714 \mathrm{~km}$ (fig. 1). For the presentation of the shoreline change analysis, New England was divided into five regions: New England North, Greater Boston, Cape Cod, Massachusetts Islands, and New England South (fig. 11a).

The geomorphology of the New England coast is highly variable (fig. 5). Rocky coastlines occur in the Northern and

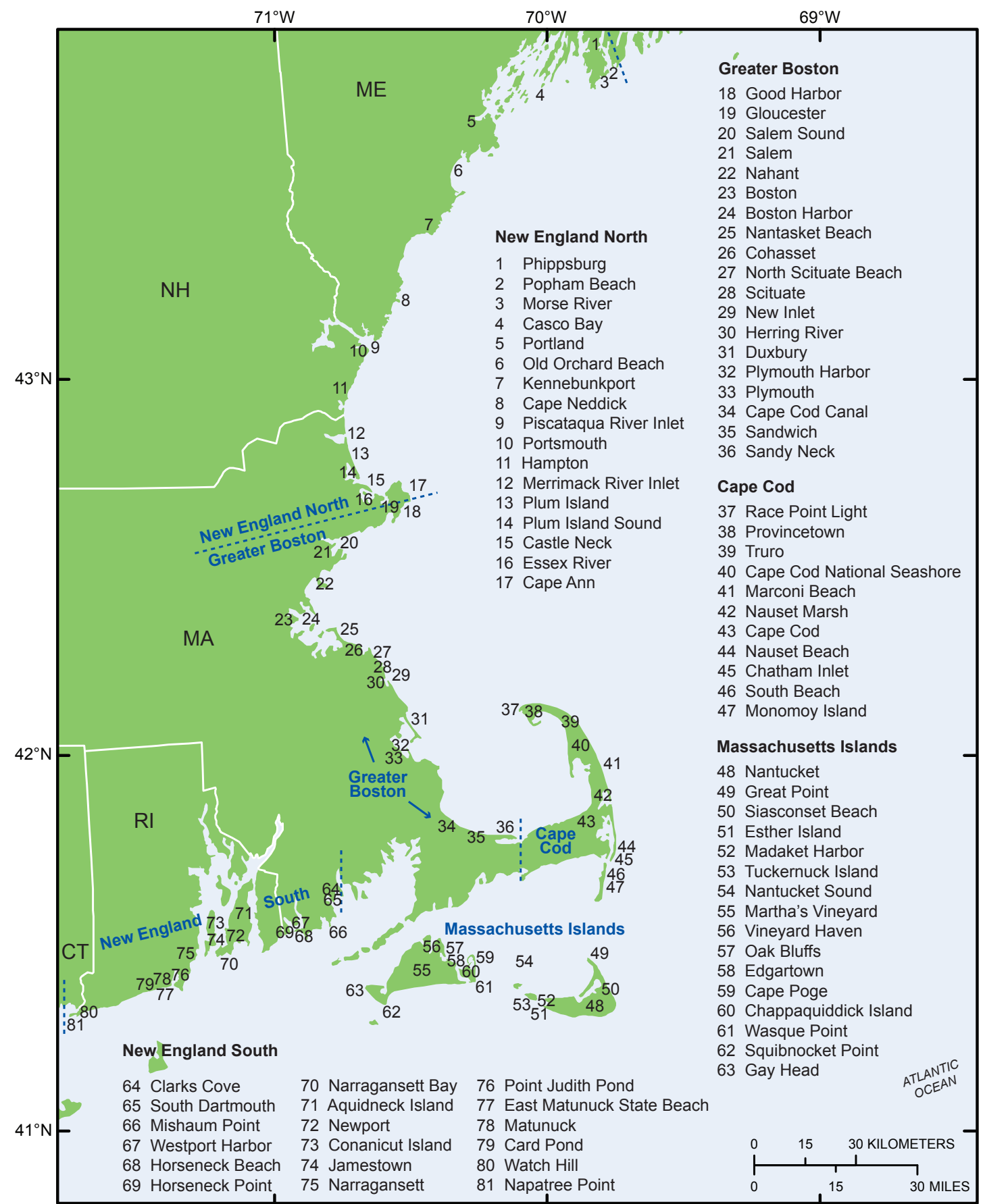

Base from Medium Resolution (1:70,000 scale, NAD 83) Digital Vector Shoreline of the coterminous United States: National Oceanic and Atmospheric Administration, 1994.
Figure 11. Index map of (A) New England and (B) the MidAtlantic showing geographic names discussed in this report. 
Southern New England regions, as well as the northern portion of the Greater Boston region. Mainland beaches backed by marshes are typically interspersed within sections of rocky coast. Barrier beaches occur in all analysis regions of New England, although they are not the long, linear barrier islands typical of the Mid-Atlantic. Bluffs fronted by narrow beaches are the least common type of coast, and occur at the northern and southern portions of the Greater Boston region, along the outer part of Cape Cod, and in small sections of the Massachusetts Islands region.
New England has a crenulated, rocky coastline with small sections of pocket beaches, except for shorelines adjacent to river mouths and a few areas where coastal bluffs are fronted by narrow beaches. As a result of this geomorphology, there are many gaps in the data; the short-term change was measured along a total of $441 \mathrm{~km}$ of the shoreline, and short-term change was measured over $307 \mathrm{~km}$. Both longterm $(-0.4 \mathrm{~m} / \mathrm{yr})$ and short-term $(-0.2 \mathrm{~m} / \mathrm{yr})$ net shoreline change rates were erosional when averaged over all of the New England transects. Of the 8,824 transects along which

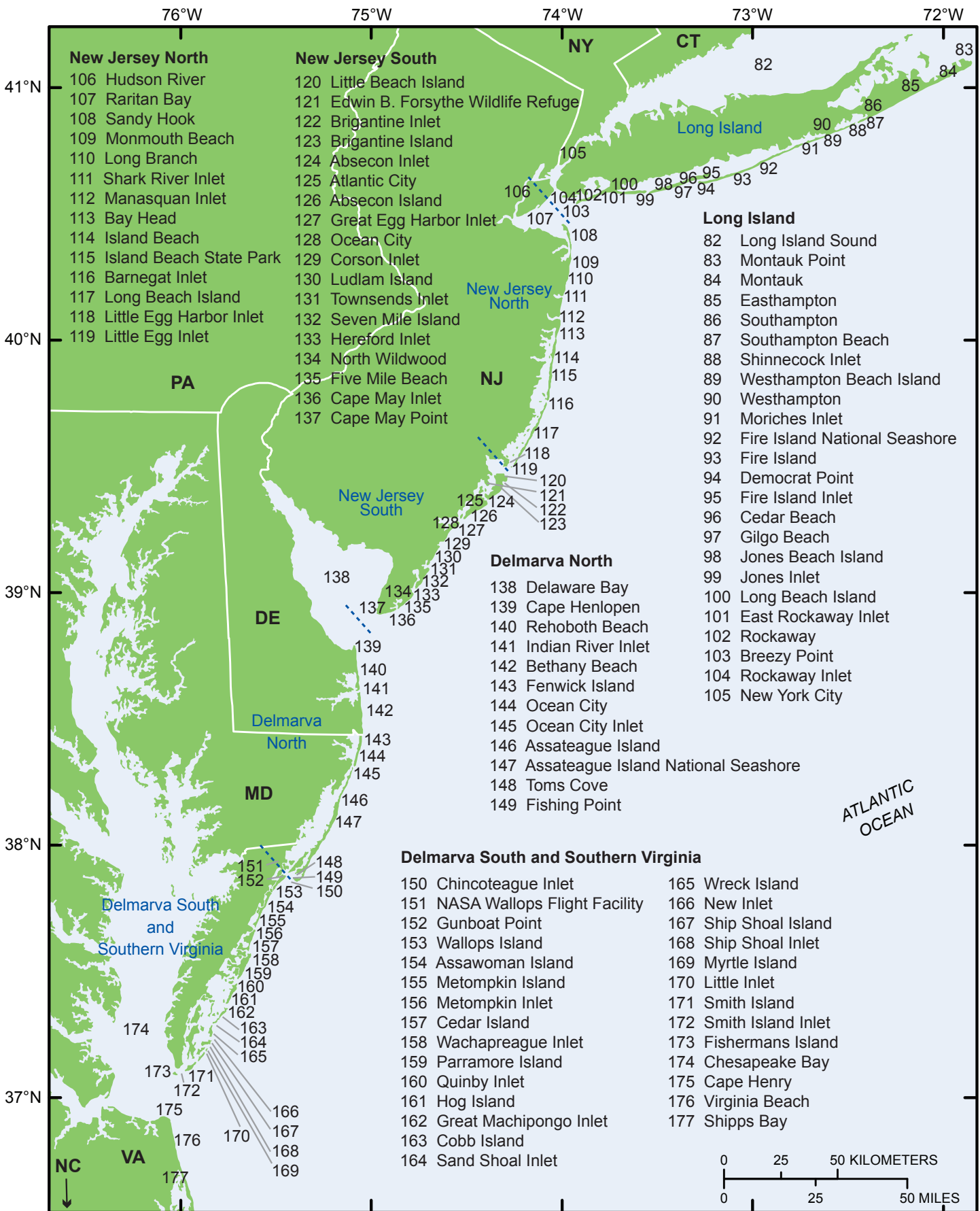

Base from Medium Resolution (1:70,000 scale, NAD 83) Digital Vector Shoreline of the coterminous United States: National Oceanic and Atmospheric Administration, 1994.
Figure 11. Index map of (A) New England and (B) the Mid-Atlantic showing geographic names discussed in this report. 


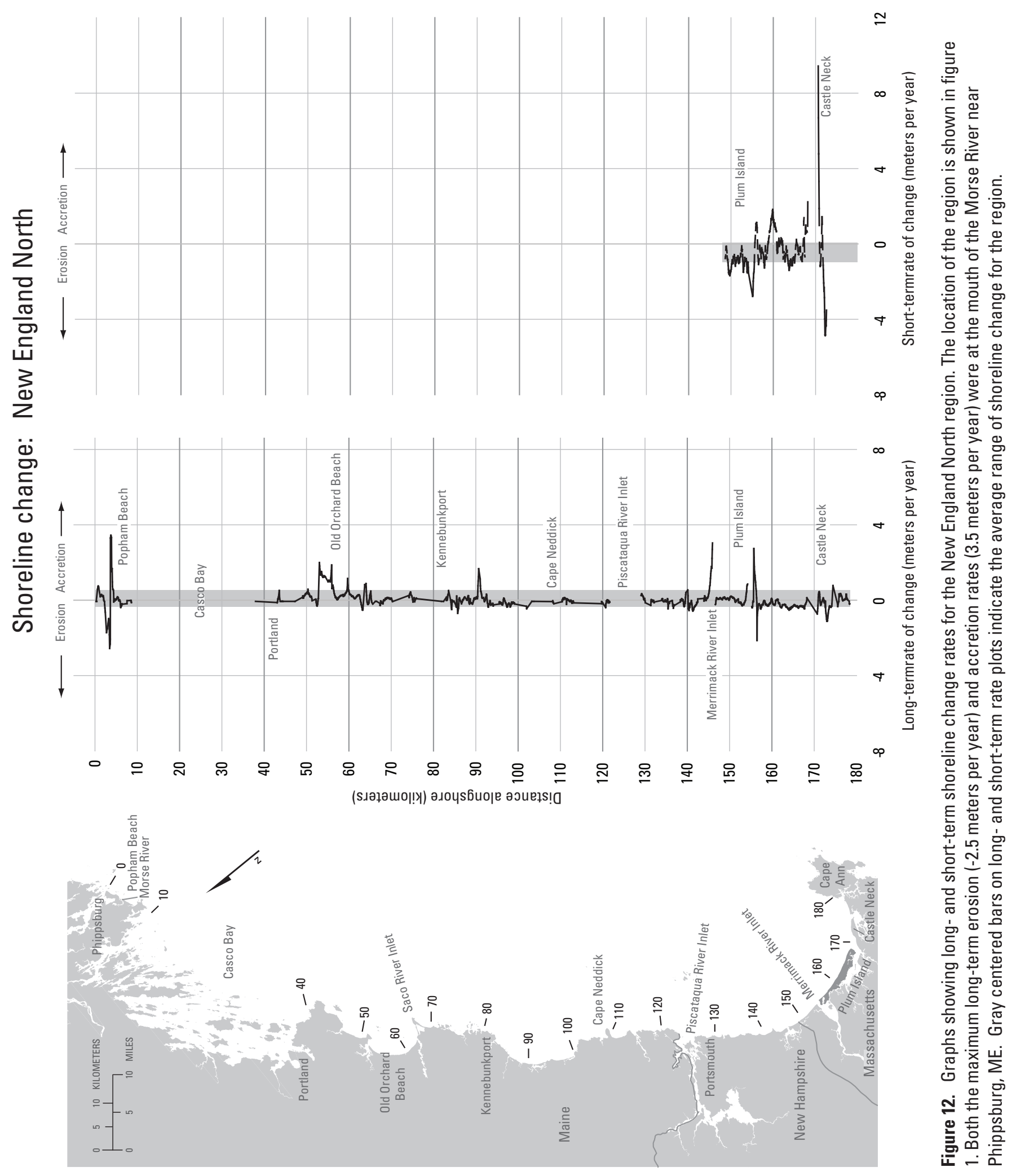


long-term shoreline change was measured, 71 percent had an erosional trend, with an average erosion rate of $-0.5 \mathrm{~m} / \mathrm{yr}$ (table 9a). For the short-term analysis, the percentage of beach eroding was 70 percent and the average short-term erosion rate increased from the long-term rate to $-2.5 \mathrm{~m} / \mathrm{yr}$ (table $9 \mathrm{~b}$ ).

\section{1: New England North Region}

The New England North region covers approximately 309 $\mathrm{km}$ of coastline and extends from Popham Beach, ME, to Castle Neck, MA, on the north side of Cape Ann (figs. 11a and 12). The New England North region includes the southern Maine coast, the New Hampshire coast, and the northernmost portion of coastal Massachusetts. The coastline in this region is sparsely developed with the exception of more moderate beach development at popular tourist centers such as Kennebunkport and Old Orchard Beach, ME; Hampton, NH; and Plum Island MA. Long stretches of the coastline are not developed and are managed as State reserves, State parks, or conservation areas. Engineering structures are restricted to jetties at some of the larger river mouths and inlets, and occasional back-beach riprap to protect homes.

For the New England North region, long-term change rates were measured along $82 \mathrm{~km}$ of shoreline. The net longterm rate, averaged over 1,642 transects, was $0.1 \mathrm{~m} / \mathrm{yr}$. Fortyone percent of transects in New England North region were experiencing erosion (average erosion rate $=-0.2 \mathrm{~m} / \mathrm{yr}$ ) in the long term, but only 2 percent of the coast was experiencing erosion rates greater than $-1.0 \mathrm{~m} / \mathrm{yr}$ (table $9 \mathrm{a}$ ). The New England North region was the only region in New England to exhibit a positive long-term net shoreline change rate, likely as a result in part of the stabilization of river mouths where high accretion rates occurred as fillets developed on the upcoast side of jetties, and from continual but localized sediment input from river systems and estuaries. Sediment yields also may have increased over the past century as development practices and deforestation in the watersheds mobilized more sediment to the coast. The maximum long-term erosion rate $(-2.5$ $\mathrm{m} / \mathrm{yr}$ ) occurred at the mouth of the Morse River near Phippsburg, ME, on the shoreline of a dynamic spit that extends across much of the river mouth (table 10a).

Short-term rates of change in the New England North region were measured only for a small section of coastline in northern Massachusetts. The lack of short-term data for New Hampshire and Maine is a result of the lack of recent (1970sera) historical shoreline data to include in end-point calculations. Consequently, short-term rates were measured along only $21 \mathrm{~km}$ of coast. The average short-term net shoreline change rate in the New England North region is erosional $(-0.4 \mathrm{~m} / \mathrm{yr})$, a significant increase over the long-term rate (table 9b). Erosion in the short term was measured on 75 percent of transects in the New England North region and rates exceeded $-1.0 \mathrm{~m} / \mathrm{yr}$ on 20 percent of transects. Both the highest short-term erosion rate $(-4.9 \mathrm{~m} / \mathrm{yr})$ and the highest short-term accretion rate were measured along Castle Neck Beach, which is a dynamic spit, just north of Cape Ann, MA (table 10a and fig. 13). The percentage of coastline eroding at rates greater than $-1.0 \mathrm{~m} / \mathrm{yr}$ increased by an order of magnitude from the long to the short term (2 to 20 percent) and the average rate of change became more erosional, indicating an increase in erosion during the later portion of the $20^{\text {th }}$ century in the New England North region.

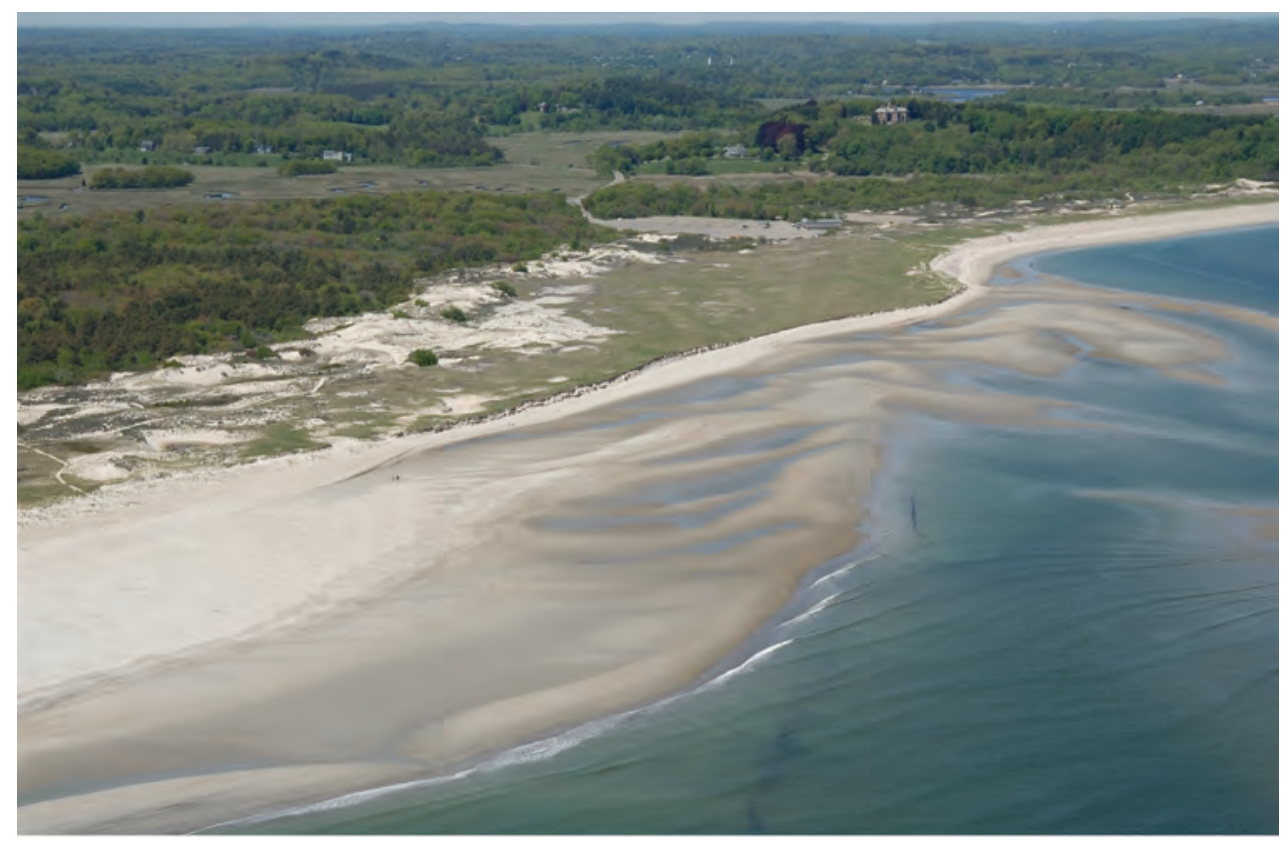

Figure 13. Oblique aerial photograph of Castle Neck, Massachusetts, in the New England North region. Both the maximum short-term erosion (-4.9 meters per year) and accretion (9.4 meters per year) rates were measured here. The average short-term change rate for the region was $-0.4 \pm 0.1$ meters per year. Photograph is taken looking toward the northwest. General location of the site is shown in figure 11a. 


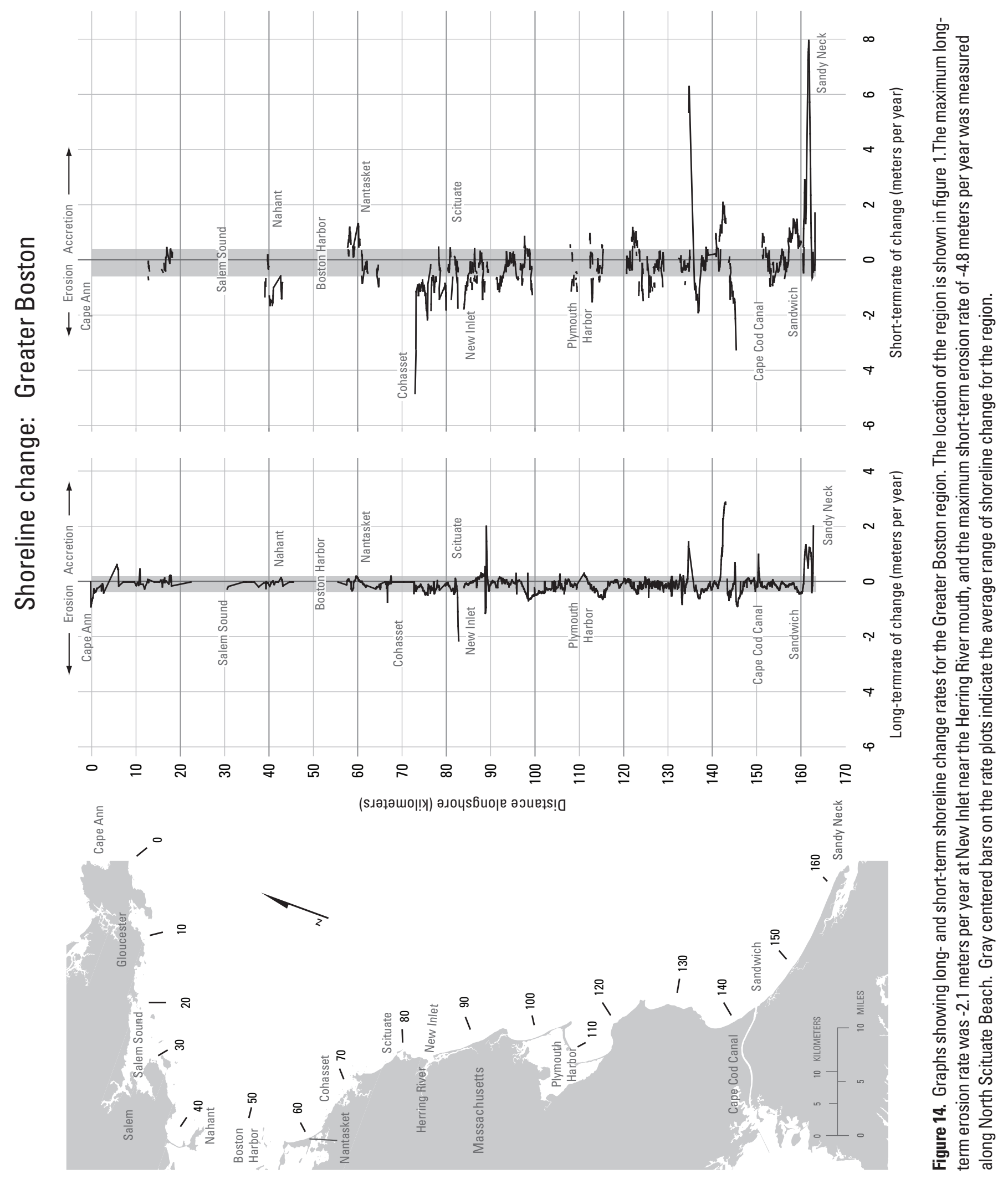




\section{2: Greater Boston Region}

The Greater Boston region extends $227 \mathrm{~km}$ from Good Harbor, MA, on the south side of Cape Ann to Sandy Neck Beach on Upper Cape Cod (figs. 11a and 14). The coastline in the Greater Boston Region falls entirely within the State of Massachusetts. The Greater Boston Region is one of the most geomorphically variable regions in New England and the Mid-Atlantic, with the northern portion dominated by rocky coastline with small pocket beaches between headlands (fig. $15 a)$. In the vicinity of Boston, mainland beaches are more dominant, and tall bluffs with narrow linear beaches occur between Plymouth and the Cape Cod Canal. Long barrier spits such as Duxbury, Plymouth, and Sandy Neck are popular tourist beaches located south of Boston (fig. 15b). The Greater Boston region is the most densely populated of the analysis regions in New England, and includes the population centers of Gloucester and Boston and towns of historical significance
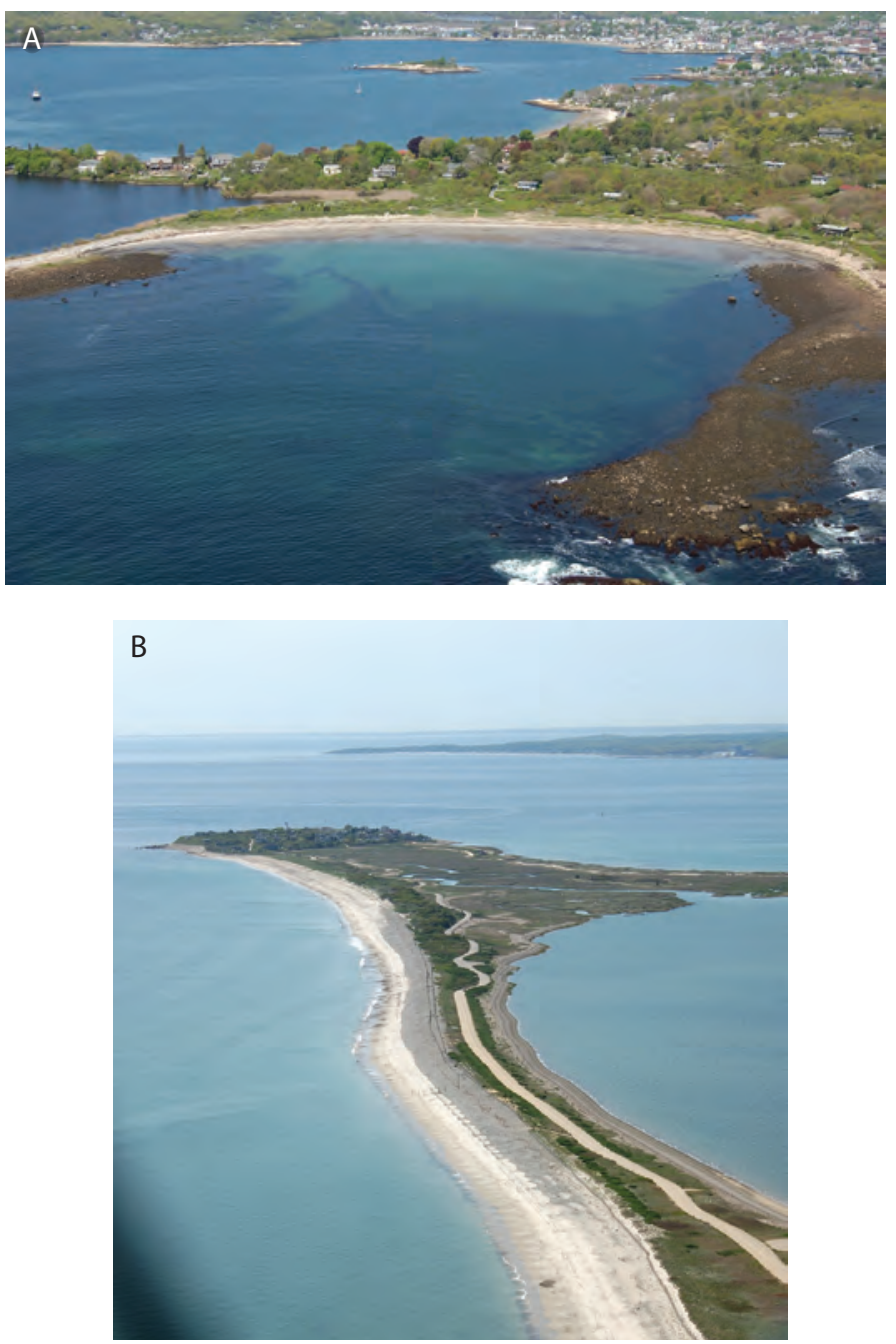

such as Salem and Plymouth. The Greater Boston region is moderately to heavily developed, and engineering structures are relatively common and include jetties and breakwaters at harbor entrances, scattered groin fields, and long stretches of riprap and seawalls. The density of structures is especially high along the more heavily populated areas.

Long-term shoreline change for the Greater Boston region was measured on 2,005 transects, covering a total of $100 \mathrm{~km}$ of coastline. The long-term net shoreline change rate for the Greater Boston region was $-0.09 \mathrm{~m} / \mathrm{yr}$, an erosional trend. Most of the measured shoreline was eroding in the long term (73 percent, average erosion rate $=-0.2 \mathrm{~m} / \mathrm{yr})($ table $9 \mathrm{a})$; however, rates exceeding $-3.0 \mathrm{~m} / \mathrm{yr}$ were measured on fewer than 1 percent of transects. The maximum erosion rate, -2.1 $\mathrm{m} / \mathrm{yr}$, was measured along a highly dynamic spit at New Inlet, at the mouth of the Herring River (table 10a). Long-term change varies considerably along the coast and rates of accretion are highest at harbor and river mouths (fig. 14), likely as a result of sediment accumulation on the updrift side of stabilizing jetties.

Short-term net average shoreline change rates for the Greater Boston region were measured along $69 \mathrm{~km}$ of coastline and averaged $-0.1 \mathrm{~m} / \mathrm{yr}$, the same net rate as in the long term. The percentage of shoreline eroding in the short term, 68 percent, decreased slightly from the long term (73 percent) (table $9 \mathrm{~b}$ ), and the averaged rate on transects with an erosional trend was $-0.6 \mathrm{~m} / \mathrm{yr}$. Less than 1 percent of transects in the Greater Boston region were eroding at rates greater than $-3.0 \mathrm{~m} / \mathrm{yr}$. The highest short-term erosion rate $(-4.8 \mathrm{~m} / \mathrm{yr})$ was measured at North Scituate Beach (table 10a) on a small pocket beach formed between rocky headlands and a large seawall. The highest short-term accretion rate occurred near the end of a barrier spit at Sandy Neck Beach near Sandwich, MA, on the upper part of Cape Cod. The rate of shoreline change in the Greater Boston region did not change from the long term to the short term; however, the percentage of coastline eroding in the more recent time period at rates greater than $-1.0 \mathrm{~m} / \mathrm{yr}$ increased significantly, from 1 to 11 percent.

Figure 15. Oblique aerial photographs of (A) Brace Cove, MA, looking west, with the city of Gloucester in the background; and (B) Duxbury Beach, MA, a popular tourist beach south of Boston, looking south, in the Greater Boston region. 


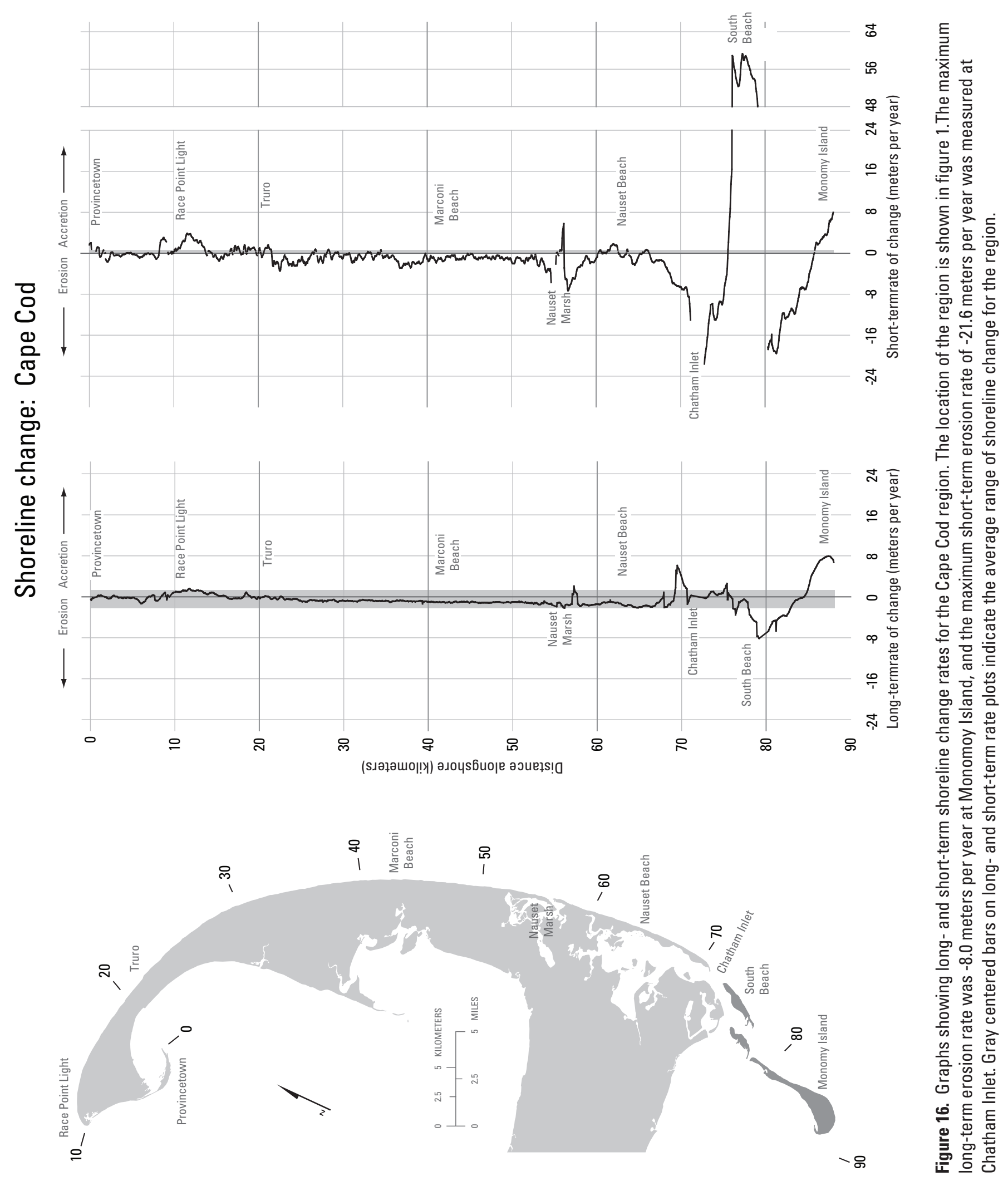




\section{3: Cape Cod Region}

The Cape Cod region extends along $88 \mathrm{~km}$ of coastline in Massachusetts and covers the region from the outer tip of Cape Cod at Provincetown to Monomoy Island (figs. 11a and 16). This portion of the New England coast is sparsely developed and most of this region lies within the boundaries of Cape Cod National Seashore. The geomorphology is almost equally divided between tall bluffs with narrow fronting beaches in the northern part of the region and barrier islands and spits to the south (fig. 17). The linear barrier system on Cape Cod is the most extensive in New England. There are no engineering structures in the Cape Cod region, making it the only region in New England and the MidAtlantic with a natural system.

Rates of shoreline change are lower and more uniform in the north and more highly variable along the southern barrier system in the Cape Cod region (fig. 16). Long-term rates of change were measured along $83 \mathrm{~km}$ of Cape Cod and the average net rate was $-0.4 \mathrm{~m} / \mathrm{yr}$ (table $9 \mathrm{a}$ ). In the long term, 74 percent of the coast was found to be eroding (erosion-only average rate $=-1.1 \mathrm{~m} / \mathrm{yr}$ ), with 23 percent of the measured shoreline eroding at rates greater than $-1.0 \mathrm{~m} / \mathrm{yr}$, and 5 percent eroding at rates greater than $-3.0 \mathrm{~m} / \mathrm{yr}$. Both the long-term erosion and accretion measurements were highest $(-8.0 \mathrm{~m} / \mathrm{yr}$ and $8.1 \mathrm{~m} / \mathrm{yr}$, respectively) on Monomoy Island (fig. 17).

The short-term rates of change in the Cape Cod region are highly variable, especially in the southern part of the region along the barrier system (fig. 16). The net short-term rate was accretional, $0.3 \mathrm{~m} / \mathrm{yr}$, and is greatly influenced by the large shoreline progradation at South Beach, south of Chatham Inlet (fig. 16). The shoreline was eroding (averaged erosion rate $=$ $-2.9 \mathrm{~m} / \mathrm{yr}$ ) along 73 percent of the $83 \mathrm{~km}$ on which short-term rates were measured (table $9 \mathrm{~b}$ ). Erosion rates exceeded -1.0 $\mathrm{m} / \mathrm{yr}$ along 42 percent of the shoreline, nearly double the percentage of long-term rates that exceeded $-1.0 \mathrm{~m} / \mathrm{yr}$. Rates exceeded $-3.0 \mathrm{~m} / \mathrm{yr}$ along 16 percent of the coast, which is also an increase from the long-term rates. The rates of both shortterm erosion $(-21.6 \mathrm{~m} / \mathrm{yr})$ and accretion $(59.3 \mathrm{~m} / \mathrm{yr})$ were highest on South Beach adjacent to Chatham Inlet, where the island underwent substantial counterclockwise rotation (erosion to the north, accretion on the south end).

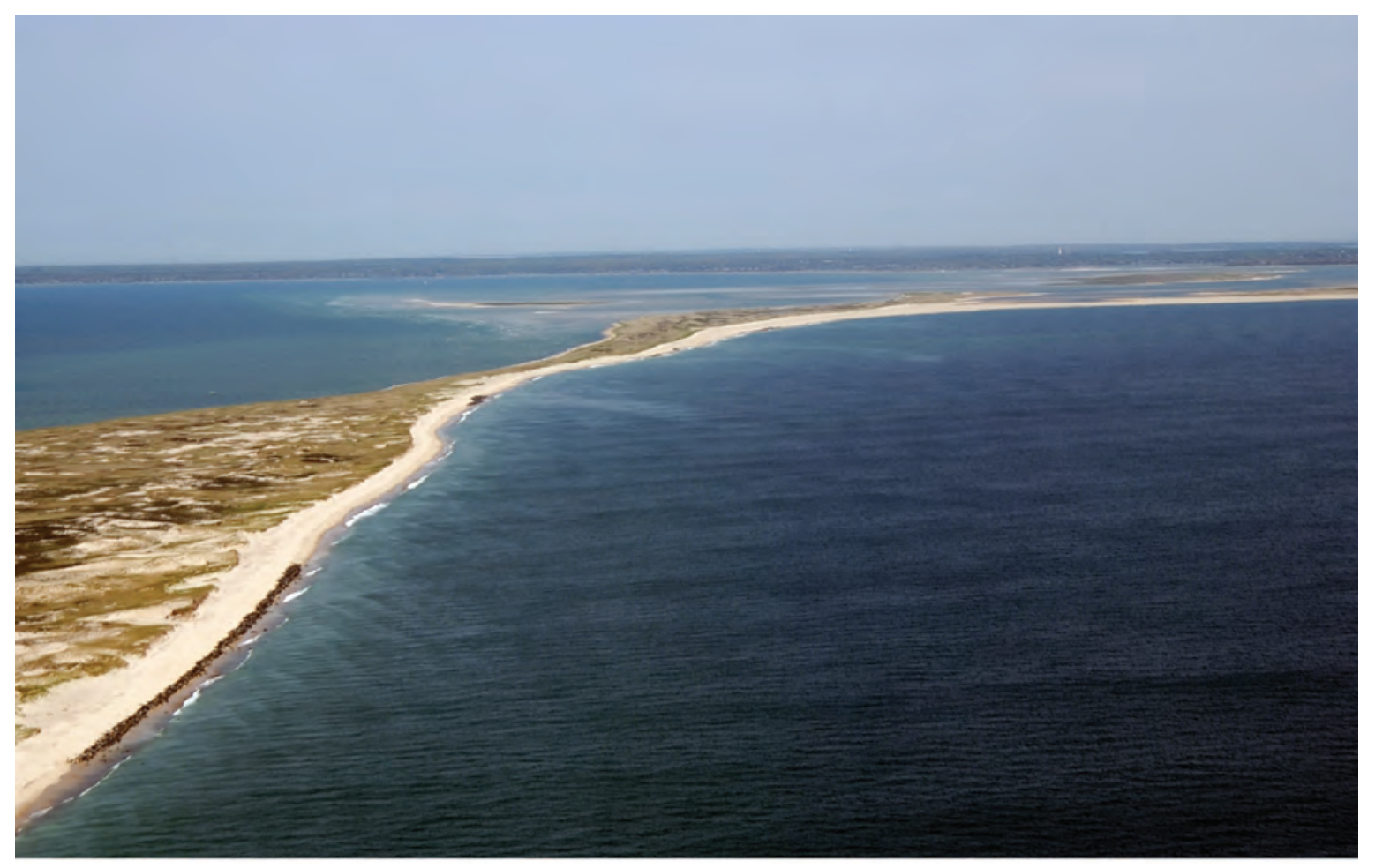

Figure 17. Oblique aerial photograph of Monomoy Island, MA, where the maximum long-term erosion (-12.1 meters per year) and accretion (8.1 meters per year) rates in the Cape Cod region were measured. The photograph is looking to the north. 


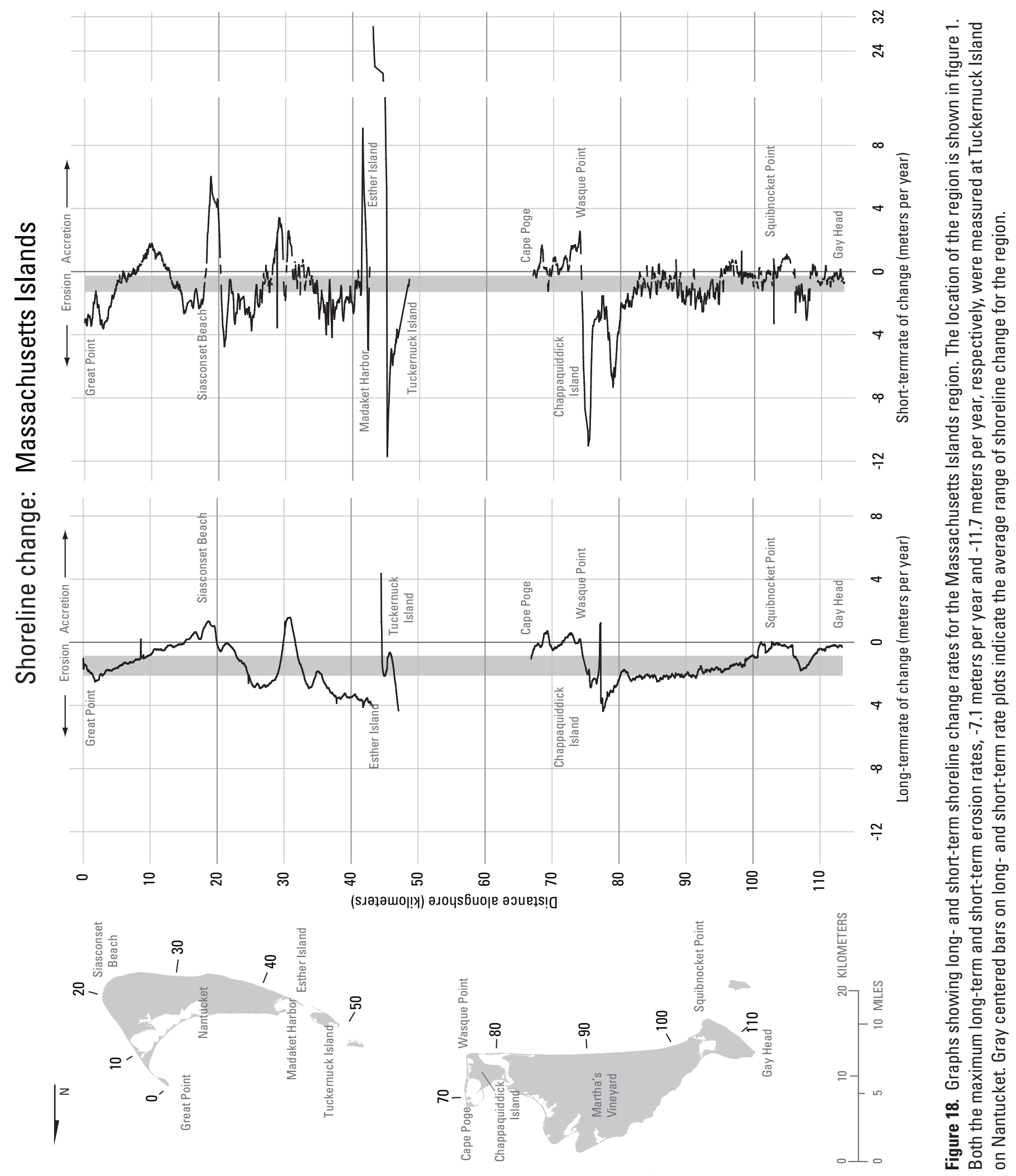




\section{4: Massachusetts Islands Region}

The Massachusetts Islands region covers the south and east coasts of Nantucket and Martha's Vineyard, a total distance of $93 \mathrm{~km}$. Shoreline change measurements were made from Great Point to Tuckernuck Island on Nantucket and from Cape Poge to Gay Head on Martha's Vineyard (figs. 11a and 18). The geomorphology of these islands includes both barrier and mainland beaches, as well as tall bluffs composed of soft glacial deposits. Barrier beaches are more predominant on Martha's Vineyard than on Nantucket, with the barriers formed as spits across the mouths of small coastal lagoons. Nantucket is moderately developed and the concentration of coastal homes is greatest along the Siasconset Beach area (fig. 11a). There are no coastal engineering structures on the open-ocean coastline of Nantucket. The open coast of Martha's Vineyard is sparsely to moderately developed. The larger population centers of Edgartown, Vineyard Haven, and Oak Bluffs are all on the Nantucket Sound side of the island. There are a few small, isolated structures (one groin, several small seawalls) in this area.

Long-term shoreline change was measured along $89 \mathrm{~km}$ of the Massachusetts Islands region. The average long-term net change was $-1.4 \mathrm{~m} / \mathrm{yr}$, the highest erosional net change in New England (table 9a). In the long term, 90 percent of the 1,775 transects in the Massachusetts Island region were erosional (average rate for erosional transects $=-1.6 \mathrm{~m} / \mathrm{yr}$ ), and rates exceeded $-1.0 \mathrm{~m} / \mathrm{yr}$ along 61 percent of the measured coast, the largest percentage in New England. The highest long-term erosion rate in the Massachusetts Islands region (-4.4 m/yr) was measured at South Beach on the southern side of Martha's Vineyard (fig. 18). The highest long-term accretion rate, 4.4

$\mathrm{m} / \mathrm{yr}$ (table 10a), was measured on Esther Island, a dynamic barrier spit at the entrance to Madaket Harbor immediately south of Tuckernuck Island on Nantucket (fig. 19).

The average net short-term rate in the Massachusetts Island region, $-0.8 \mathrm{~m} / \mathrm{yr}$, was also the most erosional of the average net rates in New England, based on measurements from 1,759 transects. Erosion occurred on 74 percent of the measured transects (average rate for erosional transects $=$ $-1.7 \mathrm{~m} / \mathrm{yr}$ ), a significant decrease from the percentage eroding in the long term (table 9b). Rates of erosion exceeded $-1.0 \mathrm{~m} / \mathrm{yr}$ along 43 percent of the shoreline, and exceeded $-3.0 \mathrm{~m} / \mathrm{yr}$ along 10 percent. The highest short-term erosion rate $(-11.7 \mathrm{~m} / \mathrm{yr}$; table $10 \mathrm{a})$ was measured on Tuckernuck Island on Nantucket, although high rates of a similar magnitude $(-11.0 \mathrm{~m} / \mathrm{yr})$ were measured at Wasque Point on the southeastern corner of Martha's Vineyard. The highest shortterm accretion rate was measured on the northwestern tip of Tuckernuck Island on Nantucket, near the location of the highest long-term accretion rate.

Rates of shoreline change in the Massachusetts Islands region became less erosional from the long to the short term. Additionally, both the total percentage of coast eroding and the percentages eroding at higher rates $(-1.0$ and $-3.0 \mathrm{~m} / \mathrm{yr})$ decreased. Regardless of the decreases in rates and percentages of erosion, the Massachusetts Islands region has the highest erosion rates and percentages of coast eroding in New England.

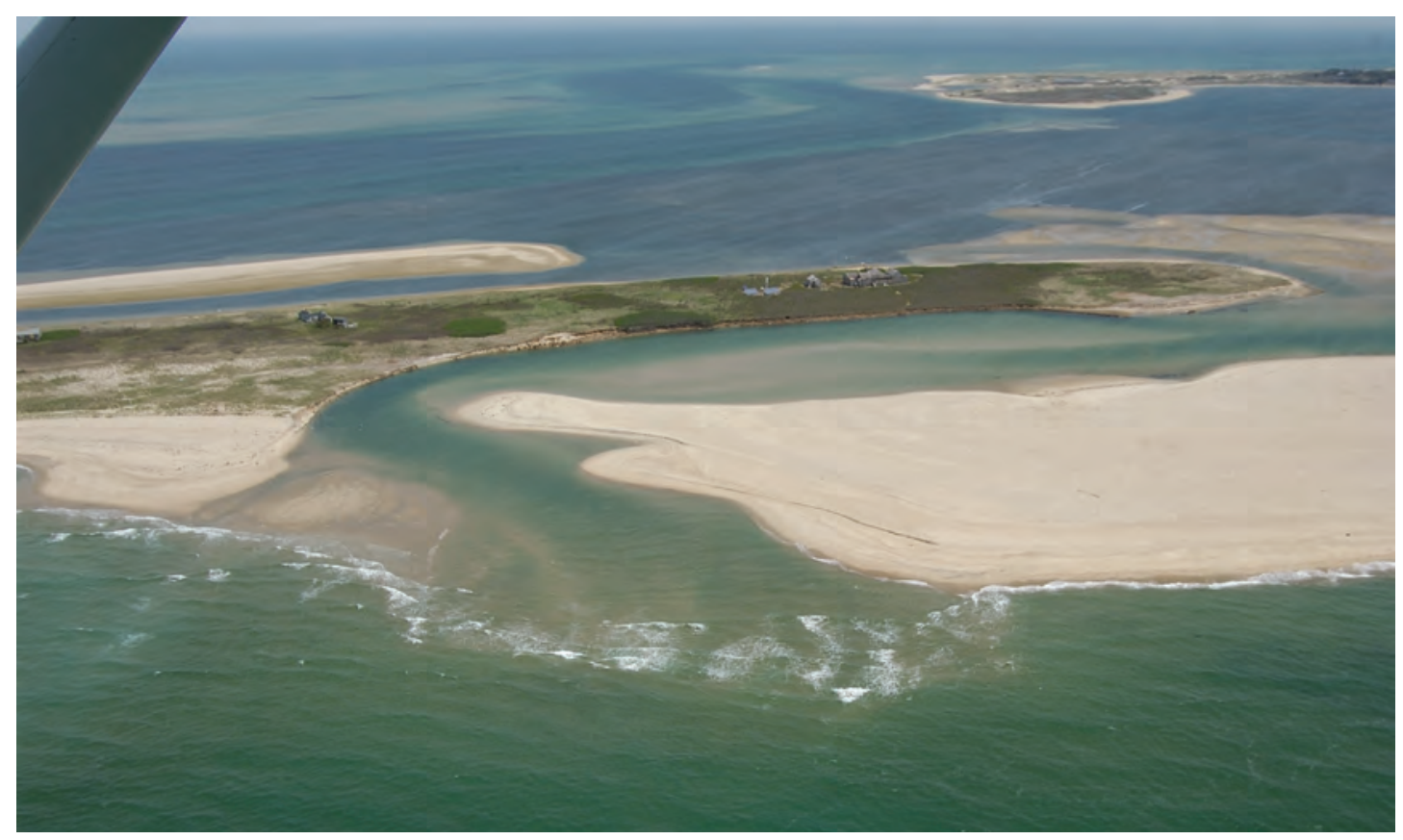

Figure 19. Oblique aerial photograph of Madaket Inlet and Esther Island in the Massachusetts Islands region. The highest long-term and short-term shoreline change rates were measured in this vicinity. Photograph is taken looking to the north. 

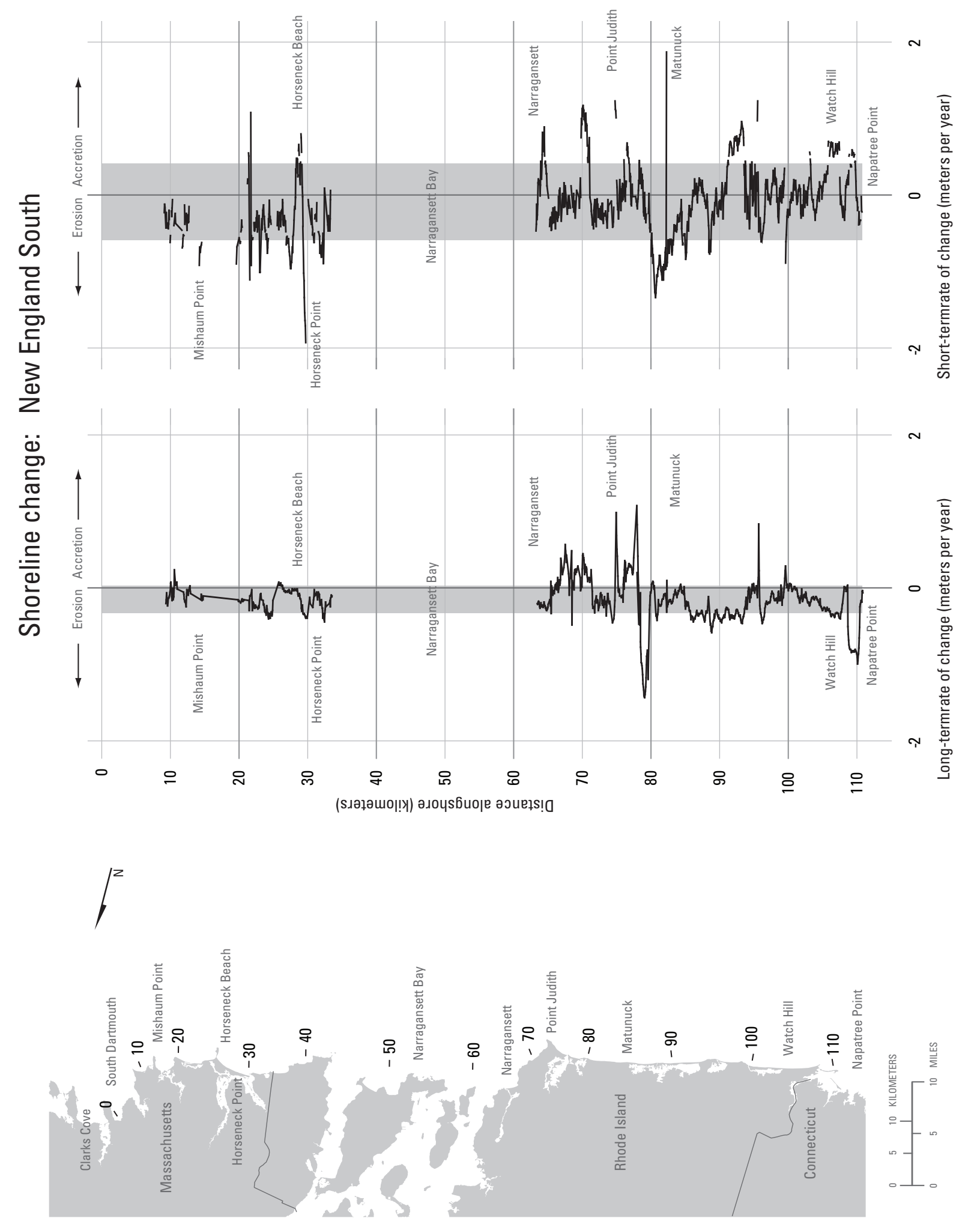


\section{5: New England South Region}

The New England South region is $111 \mathrm{~km}$ long and extends from Clarks Cove in South Dartmouth, MA, to Napatree Point, RI, at the Rhode Island-Connecticut border (figs. 11a and 20). The region ranges from moderately to densely developed. Although engineering structures exist, they are not widespread. However, structures are numerous enough to disrupt littoral transport and potentially impact the reported rates of change. Between South Dartmouth and Narragansett Bay, the coastline is predominantly mainland beaches (fig. 21a) occasionally backed by low bluffs, and stretches of rocky coastline. Narragansett Bay is a dominant feature of this region and is the largest estuary in New England. Although several of the southern islands within Narragansett Bay have open-coast beaches (Aquidneck Island and Conanicut Island, where the towns of Newport and Jamestown are located, respectively), there are gaps in the historical shoreline data. Therefore, rates of change are not reported for these beaches. Along the coastline west of Narragansett Bay, the beaches are barrier spits formed across the openings of coastal lagoons (fig. 21b). Overall, rates of shoreline change in the New England south region are variable along coast but tend to fall in a range between -1.0 and 1.0 $\mathrm{m} / \mathrm{yr}$ (fig. 20), with a few anomalous rates generally associated with coastal engineering structures or beach replenishment.
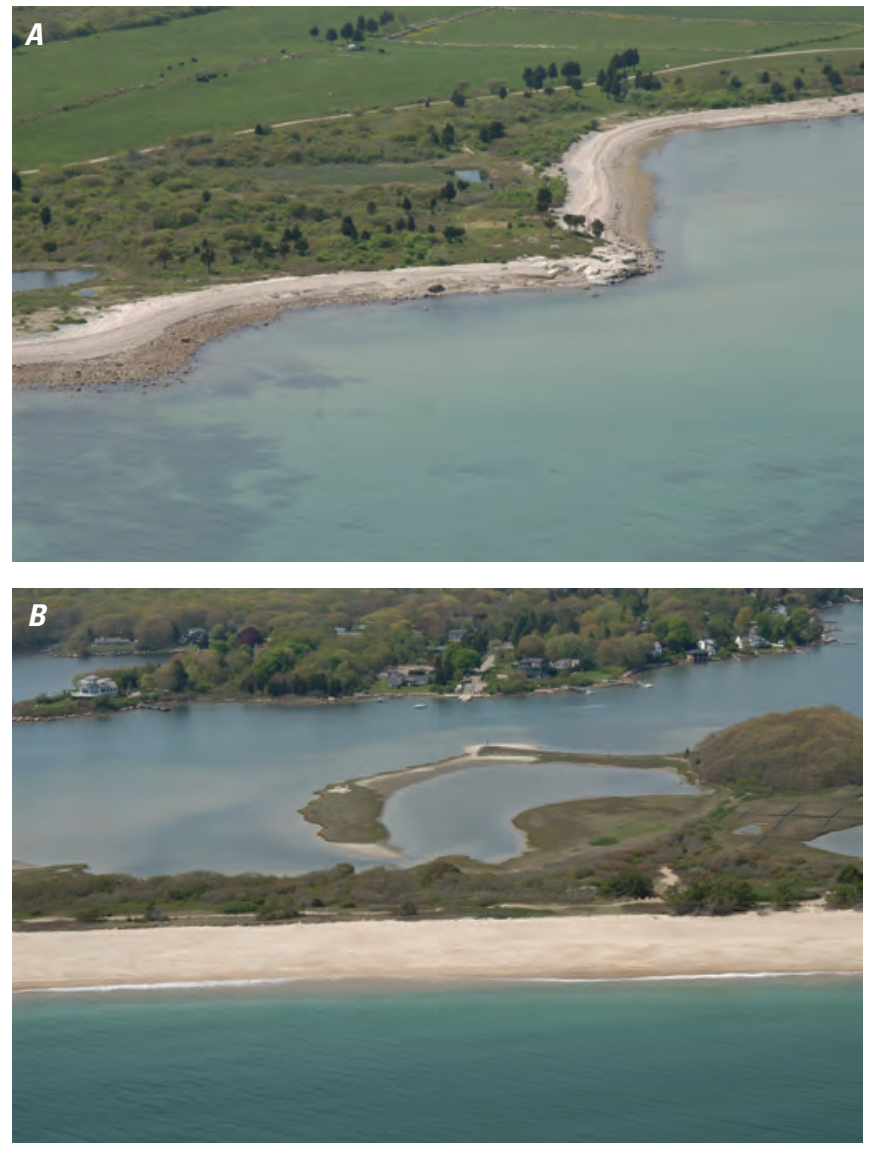

Long-term shoreline change was measured on 1,136 transects for a total coverage of $57 \mathrm{~km}$. The average net long-term rate was $-0.2 \mathrm{~m} / \mathrm{yr}$ (table $9 \mathrm{a}$ ). Eighty-four percent of the longterm rates were erosional, but only 1 percent exceeded -1.0 $\mathrm{m} / \mathrm{yr}$. Of the transects along which the shoreline was eroding, the average of the long-term erosion rates was $-0.3 \mathrm{~m} /$ yr. The highest single long-term erosion rate was $-1.4 \mathrm{~m} / \mathrm{yr}$, at East Matunuck State Beach (table 10a). The highest long-term accretion rate was $1.1 \mathrm{~m} / \mathrm{yr}$, immediately adjacent to the western jetty at the mouth of Point Judith Pond.

The net short-term rate in the New England South region, $-0.09 \mathrm{~m} / \mathrm{yr}$, was averaged from 1,135 transects along $57 \mathrm{~km}$ of coast, and is slightly lower than the long-term change rate. Gaps in the short-term record are a result of missing historical data in the eastern part of the region (fig. 20). Sixty-two percent of the measured coast was eroding in the short term (averaged erosion-only rates $=-0.4 \mathrm{~m} / \mathrm{yr}$ ). As for the long-term erosional trend, the percentage of coast eroding at rates greater than $-1.0 \mathrm{~m} / \mathrm{yr}$ was low (2 percent). The site with the highest short-term erosion rate, $-1.9 \mathrm{~m} / \mathrm{yr}$, was Horseneck Point, MA, at the entrance to Westport Habor. The highest short-term accretion rate, $1.9 \mathrm{~m} / \mathrm{yr}$, was measured at Card Pond in Matunuck, RI, at a location where a barrier inlet periodically opens and closes.

\section{Mid-Atlantic: New York to Virginia}

The Mid-Atlantic coast extends from the eastern tip of Long Island to the Virginia/North Carolina border, a total distance of approximately $644 \mathrm{~km}$ (fig. 11b). The Mid-Atlantic includes five analysis regions: Long Island, New Jersey North, New Jersey South, Delmarva North, and Delmarva South/Southern Virginia.

The Mid-Atlantic is dominated by barrier-island and barrier-spit beaches, with mainland beaches occurring along small stretches of the Long Island, New Jersey North, Delmarva North, and Delmarva South/ Southern Virginia regions (fig. 5). The only bluffed coasts in the Mid-Atlantic are along the far eastern portion of the Long Island region at Montauk, NY, and at several locations in New Jersey.

Long-term rates of change are presented for $619 \mathrm{~km}$ and short-term rates are presented for $545 \mathrm{~km}$ of sandy shoreline along the Mid-Atlantic coast. Rates are not presented for any portions of mainland coast that are fronted by barriers, or within any of the large estuaries or bays that include Raritan Bay at the mouth of the Hudson River and Chesapeake and

Figure 21. Oblique aerial photographs of locations in the New England South region: $(A)$ Slocums Neck, MA, a mainland beach looking to the west; and $(B)$ Shelter Harbor, Rl, a barrier beach more typical of the area west of Narragansett Bay, looking to the north. 


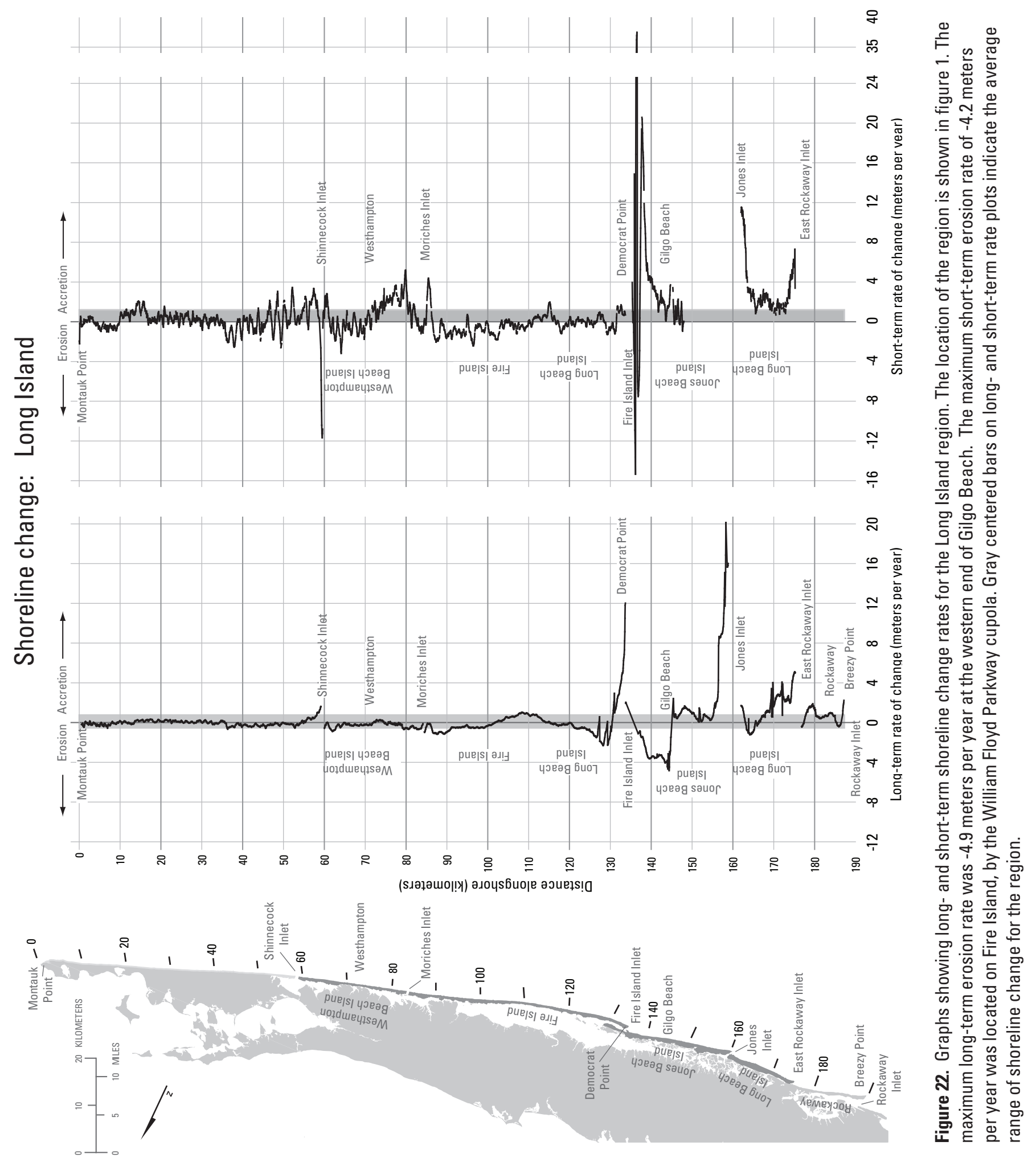


Delaware Bays. Both long-term (-0.6 m/yr) and short-term $(-0.3 \mathrm{~m} / \mathrm{yr})$ net rates of change were erosional, and greater than the net change rates in New England. Long-term rates of change were measured on 11,560 transects. Results show that 67 percent of the Mid-Atlantic was eroding in the long term and 54 percent was eroding in the short term. The overall percentage of coast undergoing erosion was smaller in the Mid-Atlantic than in New England. However, the net change rates in the Mid-Atlantic were more erosional and more of the coastline was eroding at higher rates.

\section{6: Long Island Region}

The Long Island region is $191 \mathrm{~km}$ long and extends from Montauk, NY, at the entrance to Long Island Sound to Breezy Point at the mouth of Raritan Bay, NY (figs. 11b and 22). This stretch of coast is dominated by barrier islands in the western and central parts of the region. At Southampton the barrier system joins the mainland and the elevation of the back beach increases eastward. Tall bluffs are the dominant coastal feature at and near Montauk Point. The Long Island region is moderately to densely developed, with some urbanized coastlines and several areas with no development in National, State, or county parks and wilderness areas. Development and the degree of urbanization increase with proximity to New York City. There are few visible engineering structures east of Westhampton Beach, except for several groins in the East Hampton area and a large riprap seawall at Montauk Point. There are many rock revetments and bulkheads on individual properties that are generally buried in sand except during large storms. Sand fencing is present along many portions of this region, as it is commonly used to stabilize dunes. Beginning with the jetties at Shinnecock Inlet, there are many littoral interceptors along the Long Island coast, including a groin field at Westhampton and six stabilized inlets (Shinnecock, Moriches, Fire Island, Jones, East Rockaway, and Rockaway). West of Jones Inlet, groin fields are nearly continuous along the coast. In addition to the widespread engineering structures, especially in the western portion of the Long Island region, there is a long history of beach nourishment projects (Western Carolina University, 2010). Rates of change, especially in the long term, are low and relatively uniform along coast (fig. 22). From Fire Island Inlet to Breezy Point, however, rates are highly variable. The variation in and magnitude of shoreline change rates directly correspond to the level of engineering (structures or nourishment) along the coast.

Long-term shoreline change was measured on 3,518 transects, covering $176 \mathrm{~km}$ of coastline. Both the long-term $(-0.08 \mathrm{~m} / \mathrm{yr})$ and short-term $(0.8 \mathrm{~m} / \mathrm{yr})$ net shoreline change rates were accretional (table $9 \mathrm{a}$ ). In the long term, 60 percent of the Long Island region was undergoing erosion (average of erosional rates $=-0.6 \mathrm{~m} / \mathrm{yr}$ ), with 9 percent of the measured transects experiencing erosion rates greater than $-1.0 \mathrm{~m} / \mathrm{yr}$. The maximum long-term erosion rate was along Gilgo Beach in the location of a now-closed inlet (table 10b). The maximum long-term accretion rate was $20.2 \mathrm{~m} / \mathrm{yr}$, at the western end of Jones Beach, at the tip of a spit that has accreted since it was stabilized in 1959 (fig. 23).

The percentage of coastline eroding in the Long Island region decreased from the long term (60 percent) to the short term (36 percent) (table 9a). However, the percentage of coast eroding at rates greater than $-1.0 \mathrm{~m} / \mathrm{yr}$ increased from the long term to the short term, from 9 to 15 percent. Sites of accretion are most commonly located near stabilized inlets. The maximum short-term erosion $(-4.2 \mathrm{~m} / \mathrm{yr})$ is found on Fire Island, by the William Floyd parkway cupola. The maxiumum shortterm accretion (19.6 m/yr) is found on the eastern end of Gilgo Beach, near Fire Island Inlet (table 10b).

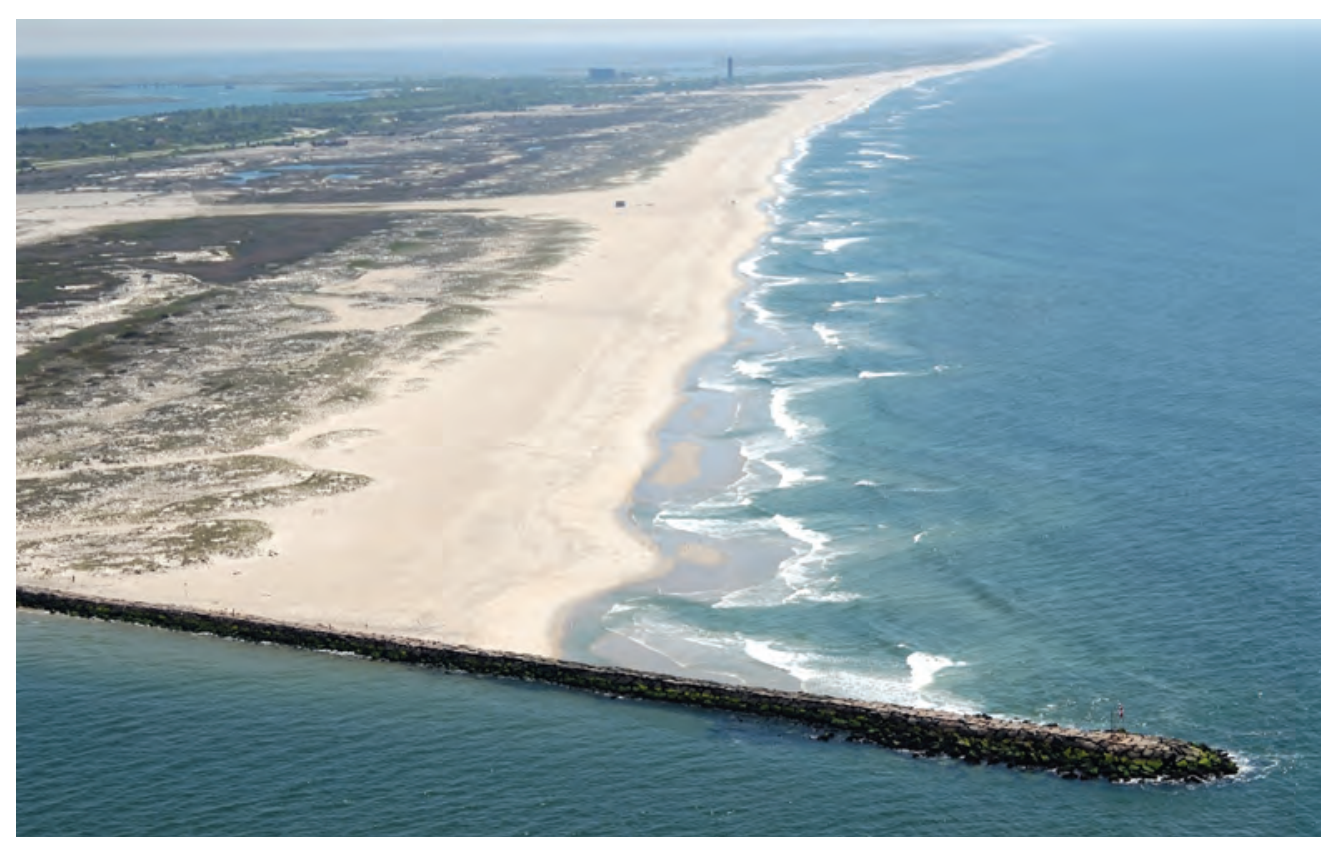

Figure 23. Oblique aerial photograph looking east along Jones Beach, NY. This is the location of the maximum longterm accretion rate (20.2 meters per year) in the Long Island analysis region. 


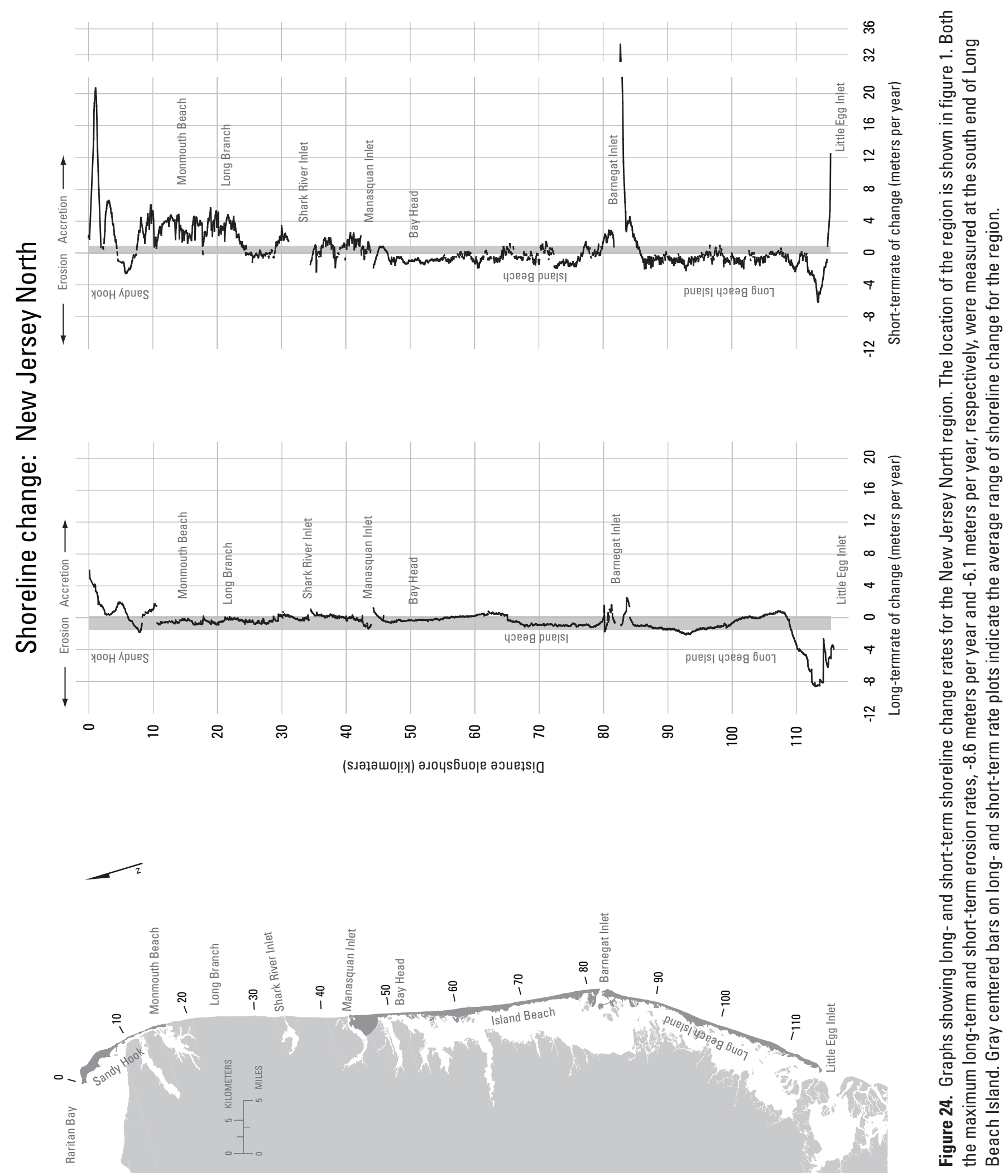




\section{7: New Jersey North Region}

The New Jersey North region is $111 \mathrm{~km}$ long and extends from Sandy Hook to Little Egg Inlet, NJ (figs. 11b and 24). The extreme northern extent of this region is a barrier spit at Sandy Hook. From approximately Monmouth Beach to Bay Head, the coastal system is composed of mainland beaches. South of Bay Head, the sandy shoreline beaches are along barrier islands and spits. The New Jersey North region is one of the most heavily engineered coasts within New England and the Mid-Atlantic, and as a result the reported rates of change reflect human modifications more than natural processes. Nearly the entire region is modified with hard structures (groins, jetties, seawalls, etc.) (fig. 25), and there is a long history of beach nourishment programs that are still ongoing. There are three stabilized inlets in the New Jersey North region: Barnegat, Manasquan, and Shark River Inlets. Little Egg Harbor is one of the few non-stabilized inlets in the New Jersey North region. Most of the region is densely to heavily developed, with the exception of the Edwin B. Forsythe Wildlife Refuge and Island Beach State Park. The patterns of regional shoreline change (fig. 24) indicate relatively lowmagnitude and low-variability trends in the central part of the area. Both the highest rates of change and the highest variability are near the major inlets. The low rates of change in the central portion are likely a result of a diminished natural signal by littoral interceptors and beach nourishment.
Long-term rates of shoreline change for the New Jersey North region were measured on 2,234 transects for a total of $112 \mathrm{~km}$ of coastline. The average net long-term rate was $-0.6 \mathrm{~m} / \mathrm{yr}$, an erosional trend (table $9 \mathrm{a}$ ). In the long term, 71 percent of the measured transects were erosional (average of erosional rates $=-1.1 \mathrm{~m} / \mathrm{yr}$ ), and 23 percent had erosion rates exceeding $-1.0 \mathrm{~m} / \mathrm{yr}$. Long-term rates greater than $-3.0 \mathrm{~m} / \mathrm{yr}$ occurred along 5 percent of the transects in the New Jersey North region. The maximum long-term erosion rate was -8.6 $\mathrm{m} / \mathrm{yr}$, at the southern end of Long Beach Island (table 10b), on the non-modified portion of the barrier spit. The highest long-term accretion rate was $5.9 \mathrm{~m} / \mathrm{yr}$, measured at the northern end of the New Jersey North region at Sandy Hook.

In the short term, the net shoreline change rate was $0.5 \mathrm{~m} / \mathrm{yr}$, a significant increase from the long-term net change rate (table $9 \mathrm{~b}$ ). The short-term rates were averaged from 2,108 transects covering $105 \mathrm{~km}$ of coast. Fifty-eight percent of the coast was undergoing erosion in the short term, a decrease from the long term (table 9b). The percentage of transects eroding at rates greater than $-1.0 \mathrm{~m} / \mathrm{yr}$ also decreased in the short term, from 23 to 3 percent. The maximum short-term erosion rate, $-6.1 \mathrm{~m} / \mathrm{yr}$, was in the same area as the long-term maximum, along the rapidly changing spit at the southern end of Long Beach Island (table 10b). The maximum short-term accretion rate, $33.6 \mathrm{~m} / \mathrm{yr}$, was at the northern end of Long Beach Island, likely as a result of the development of a fillet adjacent to the inlet jetty.

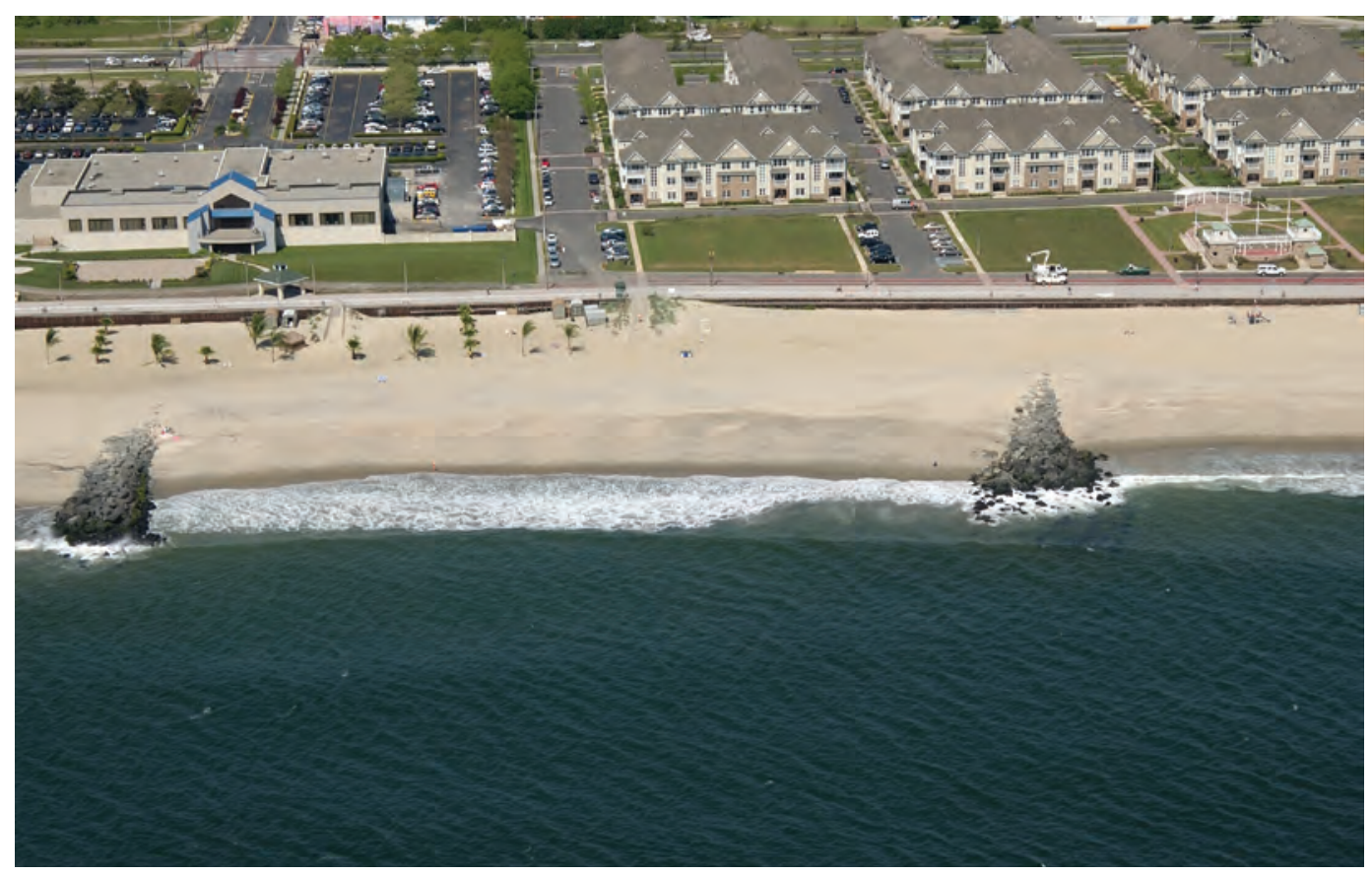

Figure 25. Oblique aerial photograph looking west along Long Branch, NJ. Groins such as those shown here are common throughout the New Jersey North region. 

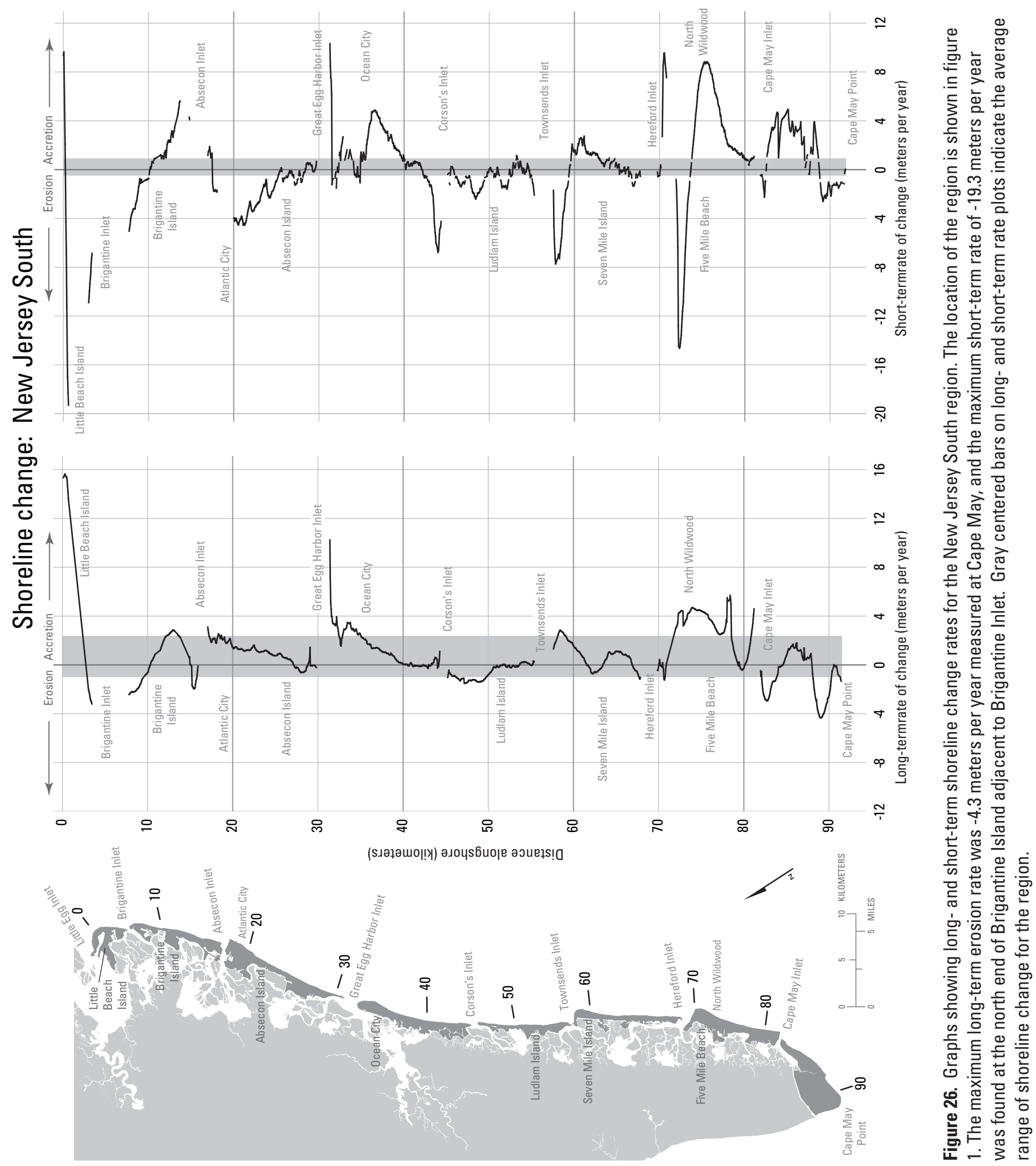


\section{8: New Jersey South Region}

The New Jersey South region extends along $86 \mathrm{~km}$ of coastline from Little Egg Inlet to Cape May Point (figs. 11b and 26). The region is composed of a series of barrier islands separated from the mainland by both coastal lagoons and extensive marshes. The barrier islands of the New Jersey South region are shorter and wider than those in the Long Island, New Jersey North, and Delmarva North regions, indicating a mixed wave- and tide-dominated system, rather than a predominantly wave-dominated system. The coast is highly engineered, with seawalls, groin fields, and jetties common along the coast. The New Jersey South region, like the New Jersey North region, has a long history of beach nourishment. Therefore, rates of shoreline change are heavily influenced by these structures and modifications to the beach. Of the eight inlets in this region, five are stabilized with jetties. The nonstabilized inlets include Little Egg, Brigantine, and Corson. Development in the region ranges from dense to urban (for example, Atlantic City and Ocean City). The patterns of shoreline change are variable along the coast (fig. 26); the highest rates of change occur adjacent to both stabilized and non-stabilized inlets.

The long-term net shoreline change rate in the New Jersey South region is strongly accretional $(0.8 \mathrm{~m} / \mathrm{yr})$, as measured on 1,408 transects covering $70 \mathrm{~km}$ of coastline (table 9a). It is the highest accretional long-term net change rate in New England and the Mid-Atlantic. Although 15 percent of the measured coast was undergoing erosion at rates greater than $-1.0 \mathrm{~m} / \mathrm{yr}$, erosion occurred on 38 percent of the total number of measured transects (average of erosional rates $=-1.0 \mathrm{~m} / \mathrm{yr}$ ), the lowest percentage in the Mid-Atlantic. The maximum long-term erosion rate $(-4.3 \mathrm{~m} / \mathrm{yr})$ was along the southern part of the region at Cape May (table 10a). A maximum accretion rate of $15.4 \mathrm{~m} / \mathrm{yr}$ was documented at the northern tip of Little Beach Island, next to a non-stabilized and sparsely developed inlet.

The averaged net short-term shoreline change rate in the New Jersey South region, $0.2 \mathrm{~m} / \mathrm{yr}$, was calculated from 1,349 transects covering $57 \mathrm{~km}$ of coastline (table $9 \mathrm{~b}$ ). The percentage of coast eroding increased from the long term to the short term (38 to 48 percent), and the percentage of coast eroding at rates greater than $-1.0 \mathrm{~m} / \mathrm{yr}$ increased to 28 percent, compared to the long-term percentage exceeding $-1.0 \mathrm{~m} / \mathrm{y}(15 \%)$. The maximum short-term erosion rate (-19.3 m/yr) was located north of Brigantine Island, adjacent to Brigantine Inlet (figure 27; table 10b). The maximum short-term accretion rate, $10.3 \mathrm{~m} / \mathrm{yr}$, was measured on the south side of Corson Inlet, and is associated with the northward migration of the inlet.

Overall, in the New Jersey South region, the amount of coast undergoing erosion increased and the rates of change became less accretional from the long to the short term. Additionally, the percentage of coast eroding at rates higher than $-1.0 \mathrm{~m} / \mathrm{yr}$ increased from 15 to 28 percent. Although rates of change were variable along the coast, the areas of greatest erosion and accretion were associated with spit migration in non-stabilized inlets.

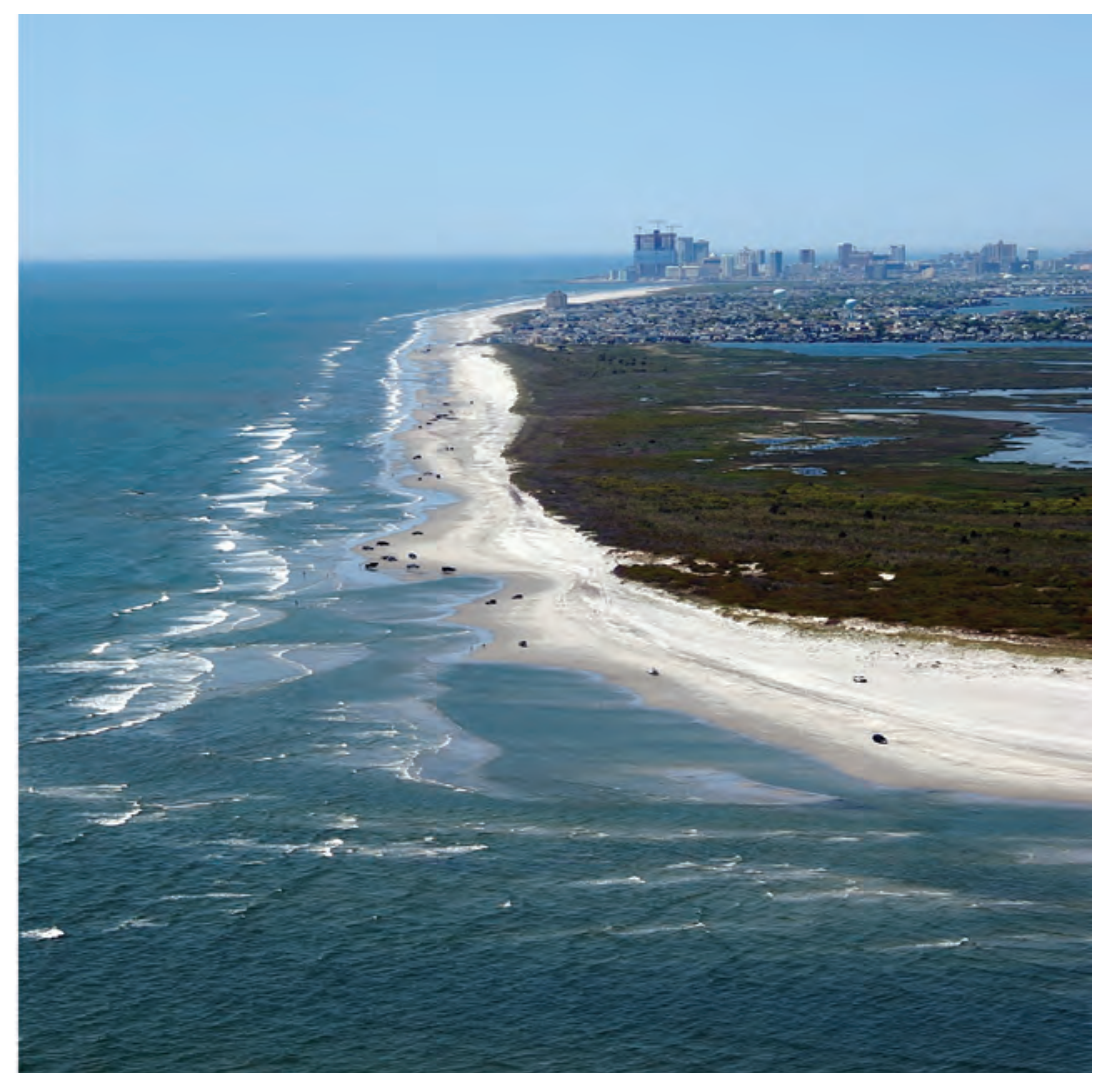

Figure 27. Oblique aerial photograph at Brigantine Inlet, looking south toward Atlantic City, NJ. This is the location of the maximum short-term erosion rate $(-19.3$ meters per year) in the New Jersey South region. 


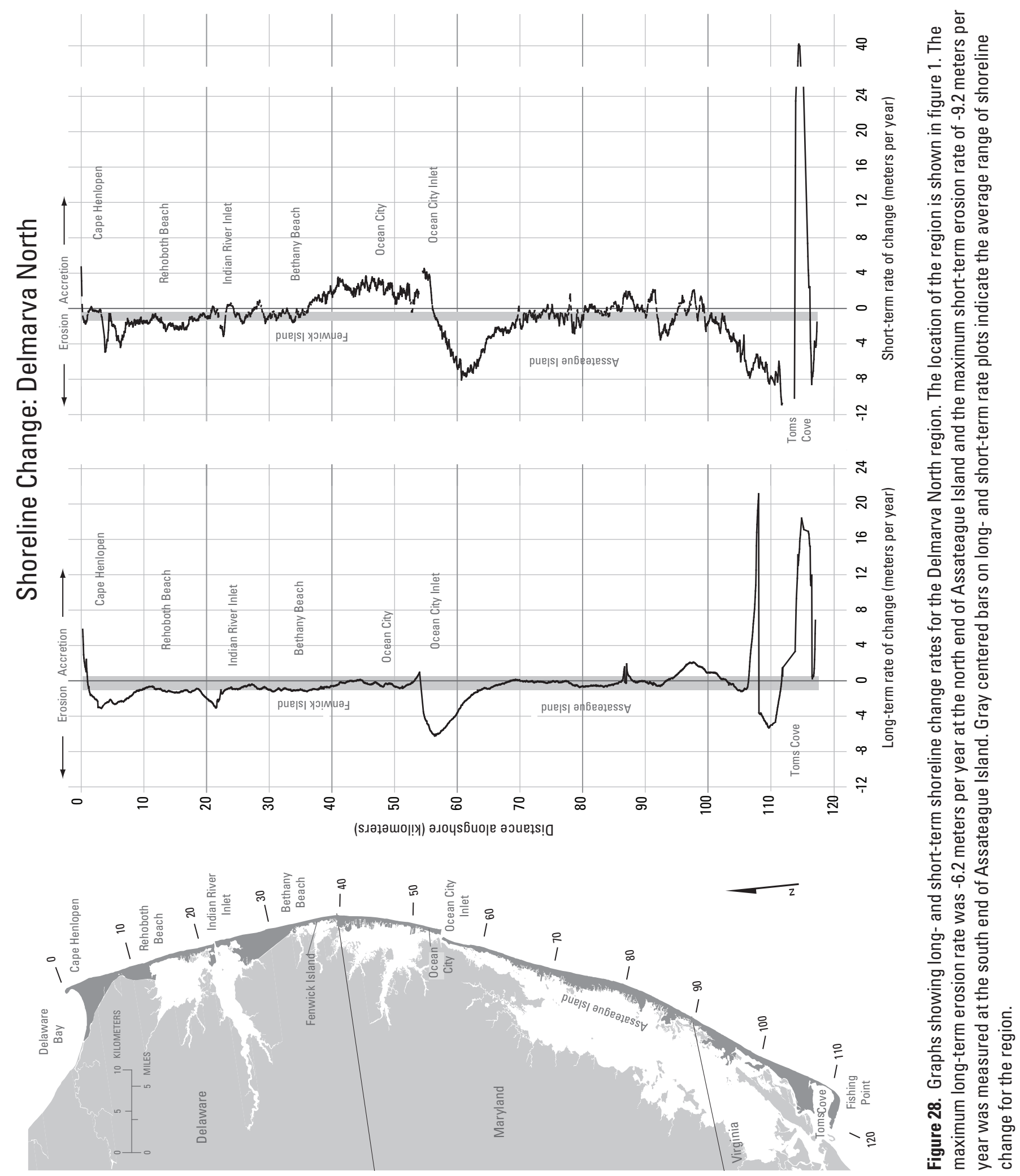




\section{9: Delmarva North Region}

The Delmarva North region extends along $114 \mathrm{~km}$ of predominantly barrier-island coast from Cape Henlopen, DE, in the north to Chincoteague Inlet at the southern end of Assateague Island, VA (figs. 11b and 28). The barrier islands in this region tend to be the long, linear barriers that are indicative of wave-dominated regimes. Development in the Delmarva North region ranges from none to urban, with the heavier development concentrated in popular tourist centers such as Rehobeth Beach, DE, and Ocean City, MD. Large stretches of nondeveloped areas include a number of State parks in Delaware and Assateague Island National Seashore in Maryland. There are only two inlets in the Delmarva North region, Indian River and Ocean City Inlets, and both are stabilized with jetties. Ocean City Inlet is commonly used as the type location for the alteration of natural coastal processes due to the presence of littoral drift interceptors and structures that fix beaches in place. South of Ocean City Inlet, Assateague Island is relatively unaltered and has migrated landward more than $500 \mathrm{~m}$, whereas Fenwick Island and the highly engineered coast of Ocean City have remained fixed since the inlet was stabilized in 1935 (fig. 29). With the exception of the inlet jetties and a few locations with small groin fields (Bethany Beach, Ocean City), there are relatively few shore-perpendicular structures in the Delmarva region. More common are hardened back-shores, including seawalls and revetments protecting houses and tourist infrastructure. These structures tend to be confined to the larger tourist centers. Nourishment, especially in Delaware and Ocean City, Maryland, was relatively widespread during the period from the 1960s to the 1990s (Western Carolina University, 2010) and less common in more recent times. Patterns of shoreline change are variable along the coast but tend to be less variable and smaller in magnitude north of Ocean City Inlet than on Assateague Island south of Ocean City Inlet. This difference is related to the efforts to stabilize the coast (through nourishment and structures) in the north, in contrast to the natural response and behavior of the coastal system on Assateague Island.

Long-term rates of change were calculated on a total of 2,235 transects covering $112 \mathrm{~km}$ in the Delmarva North region. The average net long-term change rate was $-0.5 \mathrm{~m} / \mathrm{yr}$ (table $9 \mathrm{a}$ ). Erosion occurred on 78 percent of the transects (average of erosional rates $=-1.2 \mathrm{~m} / \mathrm{yr}$ ), with 29 percent exhibiting long-term erosion rates greater than $-1.0 \mathrm{~m} / \mathrm{yr}$ and 8 percent exhibiting long-term erosion rates greater than $-3.0 \mathrm{~m} / \mathrm{yr}$. Maximum longterm rates of both erosion and accretion occurred on Assateague Island. The maximum erosion rate of $-6.2 \mathrm{~m} / \mathrm{yr}$ was on the northern end of Assateague Island approximately $1.5 \mathrm{~km}$ south of Ocean City Inlet (table 10b). The maximum accretion rate, $21.5 \mathrm{~m} / \mathrm{yr}$, was measured on the southern end of Assateague Island adjacent to Toms Cove, and is the highest long-term accretion rate measured in New England and the Mid-Atlantic.

In the short term the net change rate of $-0.8 \mathrm{~m} / \mathrm{yr}$ was averaged from 2,244 transects covering $112 \mathrm{~km}$ of coast (table 9a). The shoreline was found to be eroding along 71 percent of the measured coastline, a slight decrease from the long-term percentage. However, the percentage of coastline eroding at rates greater than $-1.0 \mathrm{~m} / \mathrm{yr}$ increased substantially from the long-term to the short term (from 29 to 45 percent) and the percentage of coast eroding at rates higher than $-3.0 \mathrm{~m} / \mathrm{yr}$ doubled. Both the maximum short-term erosion $(-9.2 \mathrm{~m} / \mathrm{yr})$ and accretion $(40.3 \mathrm{~m} / \mathrm{yr})$ rates were measured at the southern end of Assateague Island along a re-curved spit forming Toms Cove (table 10b).

In the Delmarva North region, the percentage of coastline eroding decreased slightly (from 78 to 71 percent) from the long term to the short term, but the percentage of coast eroding at higher rates increased significantly. The highest rates of change were associated with more natural areas of the coast, accentuating the highly dynamic nature of barrier island systems that have not been heavily altered by anthropogenic influences.

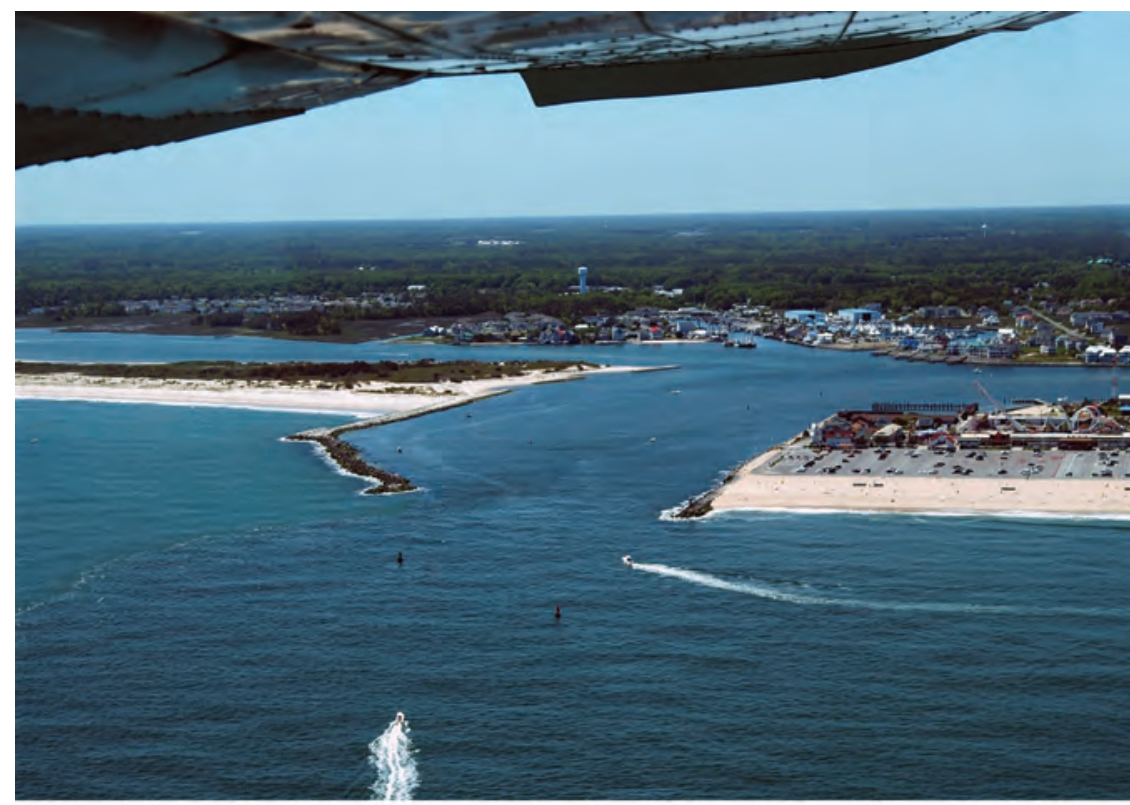

Figure 29. Oblique aerial photograph of Ocean City Inlet in the Delmarva North region. Assateague Island (on the left) has migrated more than $\mathbf{5 0 0}$ meters since the inlet was stabilized in the 1930s. Ocean City, MD, is on the north side of the inlet. 


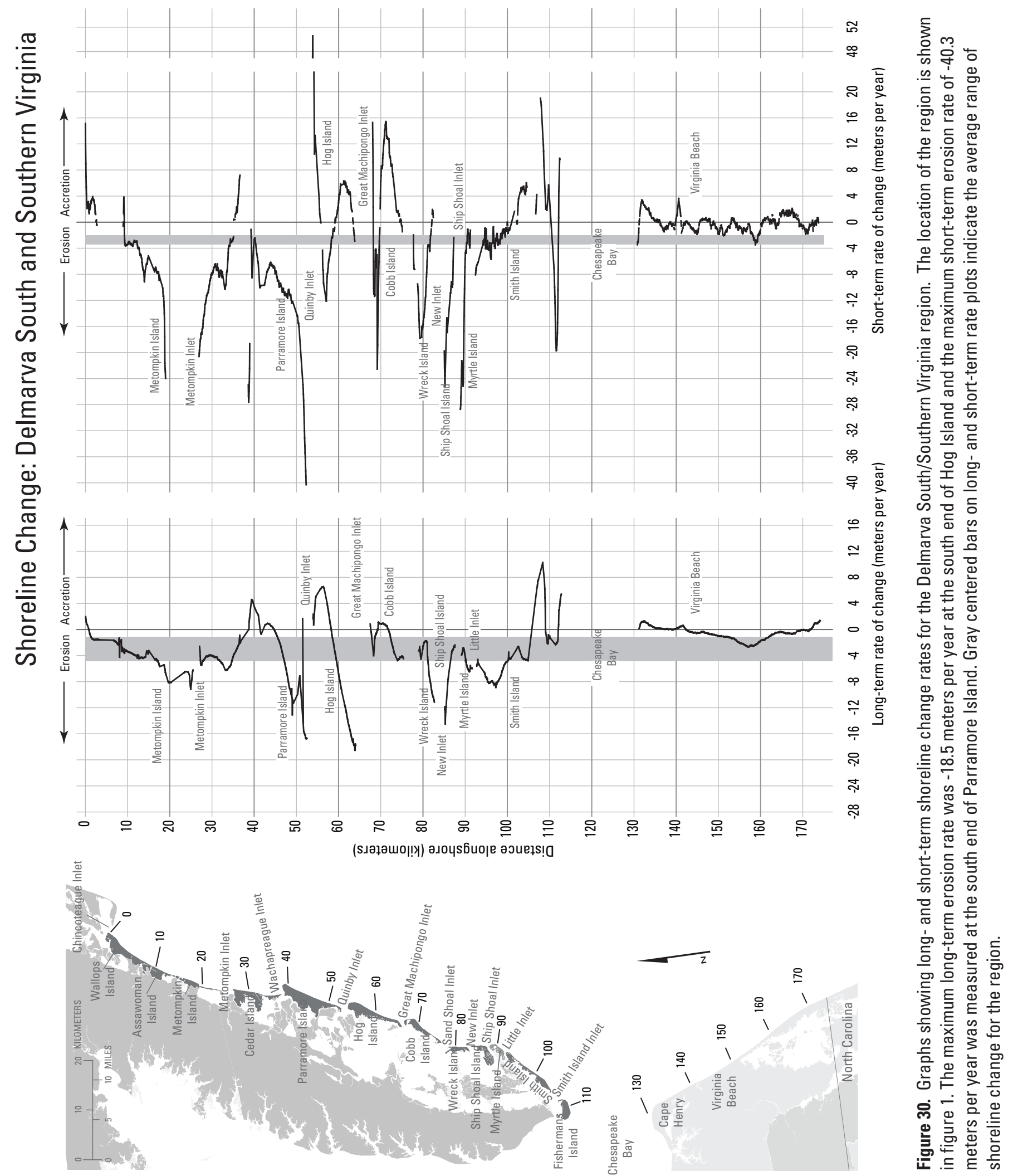




\section{0: Delmarva South/Southern Virginia Region}

The Delmarva South/Southern Virginia region extends 142 $\mathrm{km}$ from Gunboat Point at the south side of Chincoteague Inlet to the Virginia/North Carolina border near Shipps Bay (figs. 11b and 30). The region is composed of barrier islands north of the Chesapeake Bay and mainland beaches along the southern Virginia coast. The $90 \mathrm{~km}$ of coast north of the Chesapeake Bay is composed of 11 islands and 10 inlets. The short barrier islands are indicative of mixed wave- and tide-dominated coasts. With the exception of the structures at NASA's Wallops Flight Facility (including a seawall protecting facility infrastructure), the Delmarva South region north of the Chesapeake Bay is not developed and the dynamic islands are located within parks and wildlife refuges (fig. 31). South of the Chesapeake Bay, development ranges from none within a few State parks to heavy in the vicinity of Virginia Beach. In the developed areas, back beaches are commonly fixed in place with seawalls. The only groin fields in this region are shore-parallel and found in the Cape Henry area. Virginia Beach has a history of nourishment dating back to the 1950s (Western Carolina University, 2010). Patterns of shoreline change in the Delmarva South/Southern Virginia region, especially the section north of the Chesapeake Bay, are highly variable along coast. This region exhibits the greatest range of rates within the entire New England and MidAtlantic coast. Rates south of the Chesapeake Bay are lower overall, as a result of both the geomorphology (mainland as opposed to barrier beach) and dampening of natural processes through nourishment projects.

In the Delmarva South/Southern Virginia region, rates of long-term shoreline change were measured on 2,165 transects, covering a total of $108 \mathrm{~km}$ (90 north of the Chesapeake
Bay and 42 to the south). The average net long-term change rate was $-2.9 \mathrm{~m} / \mathrm{yr}$, the highest rate in this study (table $9 \mathrm{a}$ ). However, net rates in the Southern Virginia portion of the region were significantly lower, $-0.7 \mathrm{~m} / \mathrm{yr}$; the extreme shoreline change is confined to the Delmarva South coastline. In the long term, 83 percent of the transects were eroding (average of erosional rates $=-3.7 \mathrm{~m} / \mathrm{yr}$ ), with 62 percent eroding at rates greater than $-1.0 \mathrm{~m} / \mathrm{yr}$, and 40 percent eroding at rates greater than $-3.0 \mathrm{~m} / \mathrm{yr}$. The maximum long-term accretion rate was located at the eastern end of Fisherman's Island. The maximum long-term erosion rate was $-18.5 \mathrm{~m} / \mathrm{yr}$ (table $10 \mathrm{~b}$ ) and occurred on the south end of Hog Island. This is the highest long-term rate measured along the New England and Mid-Atlantic coast (fig. 30).

In the short term, rates of net shoreline change for the Delmarva South/Southern Virginia region averaged $-2.7 \mathrm{~m} / \mathrm{yr}$ (table 9b), measured along $104 \mathrm{~km}$ of coast (2,074 transects). Like the net long-term rate, the net short-term rate is the most erosional in New England and the Mid-Atlantic. Sixty-six percent of the coast is erosional in the short term. Erosion rates exceeded $-1.0 \mathrm{~m} / \mathrm{yr}$ along 50 percent of the coast, and exceeded $-3.0 \mathrm{~m} / \mathrm{yr}$ along 35 percent. The high erosion and accretion rates are focused in the area north of the Chesapeake Bay, similar to the long-term maximums. There is a range of $90.9 \mathrm{~m} / \mathrm{yr}$ in the maximum short-term erosion and accretion rates, -40.3 $\mathrm{m} / \mathrm{yr}$ and $50.6 \mathrm{~m} / \mathrm{yr}$, respectively. These rates were measured adjacent to Quinby Inlet where the barrier islands are undergoing clockwise rotation (high accretion rates on the north end and high erosion to the south). The maximum short-term erosion rate was measured on the south end of Parramore Island and the maximum short-term accretion rate was measured on the north end of Hog Island.

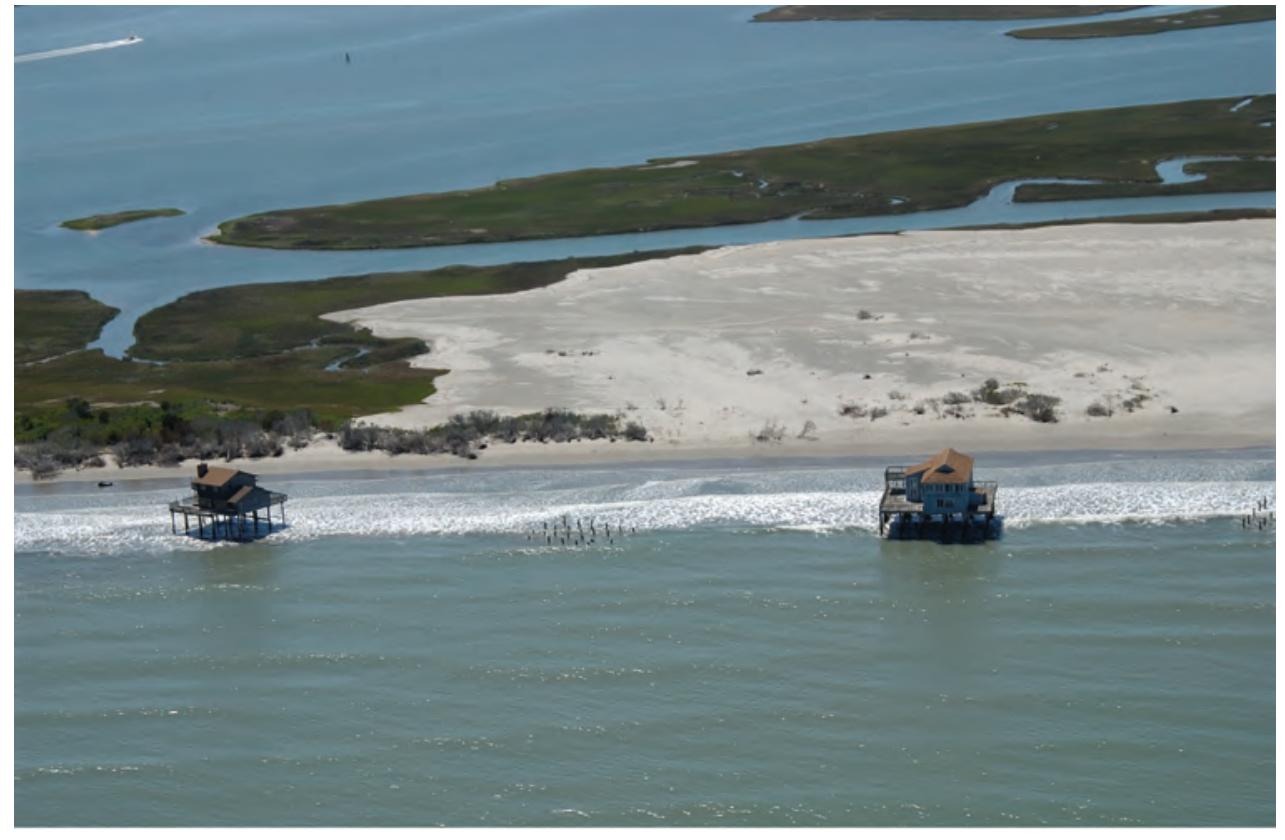

Figure 31. Oblique aerial photograph looking southwest along the southern end of Cedar Island in the Delmarva South/ Southern Virginia region. This area is experiencing long-term erosion rates greater than -3.0 meters per year. 
The Delmarva South/Southern Virginia region has the most extreme coastal change in New England and the Mid-Atlantic. Rates of shoreline change became more accretional from the long to the short term, but the percentage of coastline that was eroding decreased in the more recent time period. Maximum erosion and accretion shoreline change rates were in the Delmarva South portion of the region, north of the Chesapeake Bay.

\section{Discussion and Additional Considerations}

\section{Summary of Shoreline Changes}

The total length of the coastline in the 10 analysis regions presented in this report for New England and the Mid-Atlantic is $1,358 \mathrm{~km}$. Because of data gaps or areas with no sandy shoreline (that is, rocky coast sections), the long-term analysis represents shoreline change rates for 77 percent of the coast. There are more gaps in the data used for the short-term analysis and, as a result, rates are reported for 64 percent of the New England and Mid-Atlantic coast.

Where long-term rates of change were quantified, 65 percent of the New England and Mid-Atlantic shorelines are eroding; the highest regionally averaged long-term net rate of change, $-2.9 \mathrm{~m} / \mathrm{yr}$, occurred in the Delmarva South/Southern Virginia region. The high rates in this region are a result of the rapid rotation of drumstick barrier islands in the southern portion of the Delmarva Peninsula. The regions with the highest percentage of eroding coastline in the long-term assessment were the Delmarva South/Southern Virginia region in the MidAtlantic (83 percent eroding) and in the Massachusetts Islands region in New England, where 90 percent of the measured coast is eroding. The highest long-term erosion rate in New England and the Mid-Atlantic (-18.5 m/yr) was on the south end of Hog Island in the Delmarva South/Southern Virginia region. In New England, the highest measured long-term erosion rate, -8.0 $\mathrm{m} / \mathrm{yr}$, was on Monomoy Island in the Cape Cod region.

Overall, the percentages of coast eroding in both the long and short term were higher in New England than in the Mid-Atlantic, but the amount of coastline eroding at high rates (greater than -1.0 and $-3.0 \mathrm{~m} / \mathrm{yr}$ ) was greater in the MidAtlantic. The single highest long-term accretion rate measured in this study was $40.3 \mathrm{~m} / \mathrm{yr}$, at the southern end of Assateague Island. The high accretion rate is associated with a prograding barrier spit in a non-engineered portion of the coast.

In general, the percentage of sandy shoreline in both New England and the Mid-Atlantic that was eroding was greater in the long term (65 percent) than in the short term (60 percent); the decrease is more pronounced in the MidAtlantic (from 67 to 54 percent). Additionally, the average net shoreline change rate became less erosional from the long term $(-0.5 \mathrm{~m} / \mathrm{yr})$ to the short term $(-0.3 \mathrm{~m} / \mathrm{yr})$. However, the percentage of coastline eroding at higher rates increased from the long term to the short term in most regions, indicating an increase in erosion hazard that may be related to the impacts of sea-level rise. Less erosional trends in the net shoreline change rates are likely an artifact of an increase in nourishment projects and, in some cases, engineering structures that work temporarily to counteract the effects of increasing erosion rates.

\section{Influence of Human Activities}

As coastal communities continue to grow along the New England and Mid-Atlantic coast, potential conflicts will continue to arise between preservation of property (typically privately owned) and conservation of the beach (typically publicly owned). Past social responses indicate that these conflicts will likely be resolved through a combination of beach nourishment projects and shoreline protection structures. Both of these engineering responses to erosion alter the natural beach processes and eventually lead to artificial shoreline positions.

Adding sand to eroding beaches is a common method of storm-damage mitigation and maintaining a recreational beach. Beach nourishment alters the rates of retreat by causing rapid temporary accretion of the shoreline. In those areas where nourishment is frequent, the trends of shoreline change will be biased toward accretion or stability. Passive erosion of the beach by emplacement of seawalls or revetments may initially lead to an increase in the rate of erosion, but the rate will slow to zero when the beach in front of the structure erodes away. Many beaches are already altered by shoreline protection projects and more are likely to be altered in the future. Using methods of analyzing shoreline movement that take shoreline-stabilization activities into account will ensure that the documented trends and derived rates of change are expressed within the proper context.

Distinguishing between natural rates of shoreline movement and those influenced directly by human activities is crucial when historical rates of change are used for planning or management purposes and to forecast future shoreline positions. Improving methods of analyzing shoreline movement will help to accurately document the natural rates of shoreline change.

\section{Planned Updates and Related Research}

The USGS plans to revise and update rates of shoreline change every 5 to 10 years. Therefore, this report and associated data are a work in progress. The revision interval will depend on the availability of new information and technological advances that will allow relatively rapid shoreline position acquisition, processing, and dissemination. Future 
revisions will also incorporate the results of ongoing shoreline research. For example, we plan to continue to refine the methodology that we applied to quantify the effects of using different shoreline proxies on the shoreline change rates. The dynamics of sandy beaches ensure that short-term shoreline fluctuations will not be eliminated entirely from future shoreline positions, but data being collected in various coastal regions as part of the USGS regional studies will provide quantitative assessments of seasonal and interannual changes in shoreline position. These assessments will provide a means to determine whether the detected shoreline change is within the expected range of movement and provide additional constraint on the uncertainties.

\section{Acknowledgments}

This report was made possible by the hard work and generous cooperation of many individuals. We thank Adam Bode of the National Oceanic and Atmospheric Administration (NOAA) for providing digital historical shorelines and scans of selected NOAA topographic sheets (T-sheets), and David Doyle (NOAA) for providing datum corrections so that T-sheets could be rectified before they were digitized by the USGS. Amy Farris and Kathy Weber (USGS) contributed greatly by extracting shorelines from lidar data and calculating the proxy-datum bias. We thank Jessica Zichichi on the latest version of DSAS (v 4.1) and Ayhan Ergul of Innovate! Inc. for their programming skills on the latest version of DSAS (v4.1) and Rachel Hehre for georeferencing photos and digitizing shorelines for Rhode Island. Tara Miller (USGS) provided valuable help with compiling data sources. We would like to acknowledge Karen Morgan for taking most of the oblique aerial photographs used in this report.

\section{References Cited}

Anders, F.J., and Byrnes, M.R., 1991, Accuracy of shoreline change rates as determined from maps and aerial photographs: Shore and Beach, v. 59, p. 17-26.

Anderson, W.A., Borns, H.W.J., Kelley, J.T., and Thompson, W.B., 1989, Neotectonic activity in coastal Maine, in Anderson, W.A., and Borns, H.W.J., eds., Neotectonics of Maine: Studies in seismicity: Augusta, Maine, Maine Geological Survey, Department of Conservation, p. 1-10.

Belknap, D.F., and Kraft, J.C., 1985, Influence of antecedent geology on stratigraphic preservation potential and evolution of Delaware's barrier system: Marine Geology, v. 63, no. 1-4, p. 235-262.
Bird, J.M., and Dewey, J.F., 1970, Lithosphere plate-continental margin tectonics and the evolution of the Appalachian orogen: Geological Society of America Bulletin, v. 81, p. 1031-1061.

Clarke, A.J., 1991, The dynamics of barotropic tides over the continental shelf and slope (a review), in Parker, B.B., ed., Tidal hydrodynamics: New York, John Wiley \& Sons, Inc., p. 79-108.

Colquhoun, D.J., Johnson, G.H., Peebles, P.C., Huddleston, P.F., and Scott, T., 1991, Quaternary geology of the Atlantic coastal plain, in Morrison, R.B., ed., Quaternary nonglacial geology: Conterminus U.S.: Boulder, Colorado, Geological Society of America, p. 629-650.

Crowell, M., and Leatherman, S.P., 1999, Coastal erosion mapping and management: Journal of Coastal Research, Special Issue 28, $196 \mathrm{p}$.

Crowell, M., Leatherman, S.P., and Buckley, M.K., 1991, Historical shoreline change: Error analysis and mapping accuracy: Journal of Coastal Research, v. 7, p. 839-852.

Crowell, M., Leatherman, S.P., and Buckley, M.K., 1993, Shoreline change rate analysis: Long-term versus shortterm: Shore and Beach, v. 61, no. 2, p. 13-20.

Davis, R.E., and Dolan, R., 1993, Nor'easters: American Scientist, v. 81, p. 428-439.

Davis, R.A., and Fitzgerald, D.M., 2004, Beaches and coasts: Malden, MA, Blackwell Publishing, 419 p.

Davis, R.A., Jr., 1994, Barrier island systems - A geologic overview, in Davis, R.A., Jr., ed., Geology of Holocene barrier island systems: New York, Springer-Verlag, p. 435-456.

Demarest, J.M., and Leatherman, S.P., 1985, Mainland influence on coastal transgression - Delmarva Peninsula: Marine Geology, v. 63, no. 1-4, p. 19-33.

Dolan, R., Inman, D.L., and Hayden, B., 1990, The Atlantic coast storm of March 1989: Journal of Coastal Research, v. 6, no. 3, p. 721-725.

Dolan, R., Anders, F., and Kimball, S., 1985, Coastal erosion and accretion: National Atlas of the United States of America, U.S. Geological Survey, Reston, VA, 1 sheet, scale 1:7,500,000.

Dolan, R., Fenster, M.S., and Holme, S., 1991, Temporal analysis of shoreline recession and accretion: Journal of Coastal Research, v. 7, no. 3, p. 723-744. 
Dolan, R., Trossbach, S., and Buckley, M., 1989, Patterns of erosion along the Atlantic coast, in Barrier islands: Process and management, American Society of Civil Engineers, Coastal Zone ' 89 , 6th Symposium on Coastal and Ocean Management, Charleston, SC, July 11-14, 1989, p. 17-22.

Douglas, B.C., 2001, Sea level change in the era of the recording tide gauges, in Douglas, B.C., ed., Sea level rise: History and consequences: San Diego, Academic Press, p. 37-64.

Douglas, B.C., 2005, Gulf of Mexico and Atlantic Coast sealevel change, Circulation in the Gulf of Mexico: Observations and models: Geophysical Monograph Series: Washington, D.C., American Geophysical Union, p. 111-121.

Douglas, B.C., and Crowell, M., 2000, Long-term shoreline position prediction and error propagation: Journal of Coastal Research, v. 16, p. 145-152.

Dyke, A.S., Andrews, J.T., Clark, P.U., England, J.H., Miller, G.H., Shaw, J., and Veillette, J.J., 2002, The Laurentide and Innuitian ice sheets during the Last Glacial Maximum: Quaternary Science Reviews, v. 21, p. 9-31.

Englehart, S.E., Horton, B.P., Douglas, B.C., Peltier, W.R., and Tornqvist, T.E., 2009, Spatial variability of late Holocene and 20th century sea-level rise along the Atlantic coast of the United States: Geology, v. 37, p. 1115-1118.

Farrell, S., Lepp, T., Speer, B., and Mauriello, M., 1999, Mapping erosion hazard areas in Ocean County, New Jersey: Journal of Coastal Research, Special Issue 28, p. 50-57.

Fenneman, N.M., 1946, Physical divisions of the United States, U.S. Geological Survey map: Washington, D.C., U.S. Geological Survey, scale 1:7,000,000.

Fenster, M.S., Dolan, R., and Elder, J., 1993, A new method for predicting shoreline positions from historical data: Journal of Coastal Research, v. 9, no. 1, p. 147-171.

Fenster, M.S., and Dolan, R., 1994, Large-scale reversals in shoreline trends along the U.S. Mid-Atlantic coast: Geology, v. 22 , no. 6 , p. 543-546.

Fenster, M.S., and Dolan, R., 1999, Mapping erosion hazard areas in the city of Virginia Beach: Journal of Coastal Research, Special Issue 28, p. 58-68.

Fenster, M.S., and FitzGerald, D., 1996, Morphodynamics, stratigraphy, and sediment transport patterns in the Kennebec River Estuary, Maine, U.S.A.: Sedimentary Geology, v. 107 , no. $1-2$, p. $99-120$.

Fisher, J.J., 1968, Barrier island formation: Discussion: Geological Society of America Bulletin, v. 79, p. 1421-1426.
FitzGerald, D.M., Rosen, P.S., and van Heteren, S., 1994, New England barriers, in Davis, R.A., Jr., ed., Geology of Holocene barrier island systems: Berlin, Springer-Verlag, p. 305-394.

Fletcher, C.H., Knebel, H.J., and Kraft, J.C., 1990, Holocene evolution of an estuarine coast and tidal wetlands: Geological Society of America Bulletin, v. 102, no. 3, p. 283-297.

Forbes, D.L., and Syvitski, J.P.M., 1994, Paraglacial coasts, in Carter, R.W.G., and Woodroffe, C.D., eds., Coastal evolution - Late Quaternary shoreline morphodynamics: Cambridge, University Press, p. 373-424.

Garrett, C.J.R., and Toulany, B., 1981, Variability of the flow through the Strait of Bele Isle: Journal of Marine Research, v. 39 , p. 163-189.

Glass, R.I., O'Hare, P., and Conrad, J.L., 1979, Health consequences of the snow disaster in Massachusetts, February 6, 1978: American Journal of Public Health, v. 69, no. 10, p. 1047-1049.

Haddad, T.C., and Pilkey, O.H., 1998, Summary of the New England beach nourishment experience (1935-1996): Journal of Coastal Research, v. 14, no. 4, p. 1395-1404.

Hapke, C.J., and Reid, D., 2007, National assessment of shoreline change: Part 4: Historical coastal cliff retreat along the California coast: U.S. Geological Survey Open-File Report 2007-1133, $51 \mathrm{p}$.

Hapke, C.J., Reid, D., Richmond, B.M., Ruggiero, P., and List, J., 2006, National assessment of shoreline change: Part 3: Historical shoreline changes and associated coastal land loss along the sandy shorelines of the California coast: U.S. Geological Survey Open-File Report 2006-1219, 72 p.

Hayes, M.O., 1979, Barrier island morphology as a function of tidal and wave regime, in Leatherman, S.P., ed., Barrier islands from the Gulf of St. Lawrence to the Gulf of Mexico: New York, Academic Press, p. 211-236.

Healy, T.R., and Kirk, R.M., 1982, Coasts, in Soons, J., and Selby, M., eds., Landforms of New Zealand: Auckland, Longman-Paul, p. 80-104.

Heinz Center, 2000, Evaluation of erosion hazards: Washington, D.C., The H. John Heinz III Center for Science, Economics and the Environment, 203 p.

Himmelstoss, E.A., 2009, DSAS 4.0 Installation Instructions and User Guide, in Thieler, E.R., Himmelstoss, E.A., Zichichi, J.L., Ergul, A., 2009, Digital Shoreline Analysis System (DSAS) version 4.0 - An ArcGIS extension for calculating shoreline change: U.S. Geological Survey Open-File Report 2008-1278, available at http://woodshole.er.usgs.gov/project-pages/dsas/version4/. 
Himmelstoss, E.A., Kratzmann, M., Hapke, C.J., Thieler, E.R., and List, J., 2010, The national assessment of shoreline change - A GIS compilation of vector shorelines and associated shoreline change data for the New England and MidAtlantic coasts: U.S. Geological Survey Open-File Report 2010-1119, available at http://pubs.usgs.gov/of/2010/1119/.

Houston, J.R., 2003, The coastal structure debate - Public and policy aspects, in Mohan, R.K., Magoon, O., and Pirrello, M., eds., American Society of Civil Engineers, Advances in Coastal Structure Design: Reston, VA, p. 1-17.

Hughes, T., Borns, H.W., Fastook, J.L., Hyland, M.R., Kite, J.S., and Lowell, T.V., 1985, Models of glacial reconstruction and deglaciation applied to Maritime Canada and New England, in Borns, H.W., Jr., LaSalle, P., and Thompson, W.B., eds., Late Pleistocene history of northeastern New England and adjacent Quebec: Geological Society of America Special Paper 197, p. 139-150.

Inman, D.L., and Nordstrom, C.E., 1971, On the tectonic and morphologic classification of coasts: Journal of Geology, v. 79 , no. 1, p. 1-21.

Jensen, R.E., 1983, Atlantic coast hindcasting shallow water significant wave information: Wave Information Study Report, Vicksburg, MS, v. 8, p. 75.

Kaye, C.A., 1964, Outline of Pleistocene geology of Martha's Vineyard, Massachusetts: U.S. Geological Survey Professional Paper 501-C, p. C134-C139.

Kelley, J.T., 1987, An inventory of coastal environments and classification of Maine's glaciated shoreline, in Fitzgerald, D.M., and Rosen, P.S., eds., Glaciated coasts: London, Academic Press, Inc., p. 151-176.

Kelley, J.T., 2004, Coastal bluffs of New England, in Hampton, M.A., and Griggs, G.B., eds., Formation, evolution, and stability of coastal cliffs - Status and trends: U.S. Geological Survey Professional Paper 1693, p. 95-105.

Kelley, J.T., Dickson, S.M., Belknap, D.F., and Stuckenrath, R.J., 1992, Sea-level change and Quaternary sediment accumulation on the southern Maine inner continental shelf, in Fletcher, C., and Wehmiller, J., eds., Quaternary coasts of the United States: Marine and lacustrine systems: Society of Economic and Paleontologic Mineralogy Spec. Pub., p. 23-34.

Krabill, W., Wright, C., Swift, R., Frederick, E., Manizade, S., Yungel, J., Martin, C., Sonntag, J., Duffy, M., Hulslander, W., and Brock, J., 2000, Airborne laser mapping of Assateague National Seashore Beach: Photogrammetric Engineering \& Remote Sensing, v. 66, p. 65-71.
Kraft, J.C., 1971, Sedimentary facies patterns and geologic history of a Holocene marine transgression: Geological Society of America Bulletin, v. 82, no. 8, p. 2131-2158.

Larson, G.J., 1982, Nonsynchronous retreat of ice lobes from southeastern MA, in Larson, G.J., and Stone, B.D., eds., Late Wisconsinian of New England: Dubuque, Kendell/ Hunt, p. 101-114.

Leatherman, S.P., 1979, Migration of Assateague Island, Maryland, by inlet and overwash processes: Geology, v. 7, no. 2, p. 104-107.

Leatherman, S.P., 1985, Geomorphic and sedimentary analysis of Fire Island, New York: Marine Geology, v. 63, no. 1-4, p. 173-195.

Leatherman, S.P., and Anders, F.J., 1999, Mapping and managing coastal erosion hazards in New York: Journal of Coastal Research, Special Issue 28, p. 34-42.

Leatherman, S.P., and Eskandary, L.S., 1999, Evaluation of coastal erosion hazards along Delaware's Atlantic Coast: Journal of Coastal Research, Special Issue 28, p. 43-49.

Leitch, E.C., 1975, Plate tectonic interpretation of the Paleozoic history of the New England Fold Belt: Geological Society of America Bulletin, v. 86, no. 1, p. 141-144.

Marrone, J.F., 2008, Evaluation of impacts of the Patriots' Day storm (April 15-18, 2007) on the New England coastline, in American Society of Civil Engineers, Proceedings of the Solutions to Coastal Disasters Congress, Oahu, HI, April 13-16, v. 312, p. 46.

Meade, R.H., and Emery, K.O., 1971, Sea level as affected by river runoff, eastern United States: Science, v. 173, no. 3995, p. 425-428.

Moore, L., Ruggiero, P., and List, J., 2006, Comparing mean high water and high water line shorelines: Should proxydatum offsets be incorporated in shoreline change analysis?: Journal of Coastal Research, v. 22, no. 4, p. 894-905.

Moore, L.J., 2000, Shoreline mapping techniques: Journal of Coastal Research, v. 16, p. 111-124.

Morang, A., Rahoy, D.S., and Grosskopf, W.G., 1999, Regional geologic characteristics along the south shore of Long Island, New York, in American Society of Civil Engineers, Coastal Sediments '99, Proceedings of the 4th International Symposium on Coastal Engineering and Science of Coastal Sediment Processes, Long Island, New York, p. 1568-1583.

Morton, R.A., 1991, Accurate shoreline mapping: Past, present, and future, in American Society of Civil Engineers, Coastal Sediments '91, Proceedings of a Specialty Conference on Quantitative Approaches to Coastal Sediment Processes, Seattle, WA, June 25-27, v. 1, p. 997-1010. 
Morton, R.A., 1996, Geoindicators of coastal wetlands and shorelines, in Berger, A.R., and Iams, W.J., eds., Geoindicators: Assessing rapid environmental changes in earth systems: Rotterdam, A.A. Balkema, p. 207-230.

Morton, R.A., and Miller, T.L., 2005, National assessment of shoreline change: Part 2: Historical shoreline changes and associated coastal land loss along the U.S. Southeast Atlantic Coast: U.S. Geological Survey Open-File Report 2005-1401, 35 p.

Morton, R.A., Miller, T.L., and Moore, L.J., 2004, National assessment of shoreline change: Part 1: Historical shoreline changes and associated coastal land loss along the U.S. Gulf of Mexico: U.S. Geological Survey Open-File Report 20041043, 45 p.

Morton, R.A., and Sallenger, A.H., 2003, Morphological impacts of extreme storms on sandy beaches and barriers: Journal of Coastal Research, v. 19, no. 3, p. 560-573.

Morton, R.A., and Speed, F.M., 1998, Evaluation of shorelines and legal boundaries controlled by water levels on sandy beaches: Journal of Coastal Research, v. 14, no. 4, p. 1373-1384.

Niederoda, A.W., Swift, D.J.P., Figgueiredo, A.G., and Freeland, G.L., 1985, Barrier island evolution, middle Atlantic shelf, USA, Part II: Evidence from the shelf floor: Marine Geology, v. 63, no. 1-4, p. 363-396.

Nummendal, D., Oertel, G.F., Hubbard, D.K., and Hine, A.C., 1977, Tidal inlet variability: Cape Hatteras to Cape Canaveral, in American Society of Civil Engineers, Coastal Sediments '77, Charleston, SC, Nov. 2-4, 1977, p. 543-562.

O’Connell, J.F., and Leatherman, S.P., 1999, Coastal erosion hazards and mapping along the Massachusetts shore: Journal of Coastal Research, Special Issue 28, p. 27-33.

Oertel, G.F., 1985, The barrier island system: Marine Geology, v. 63 , no. $1-4$, p. 1-18.

Oldale, R.N., 1982, Pleistocene stratigraphy of Nantucket, Martha's Vineyard, the Elizabeth Islands, and Cape Cod, Massachusetts, in Larson, G.J., and Stone, B.D., ed., Late Wisconsinan glaciation of New England: Proceedings of the Symposium: Dubuque, Iowa, Kendall/Hunt, p. 1-34.

Oldale, R.N., and O'Hara, C.J., 1980, New radiocarbon dates from the inner continental shelf off southeastern Massachusetts and a local sea-level rise curve for the past 12,000 years: Geology, v. 8, p. 102-106.

Pajak, M.J., and Leatherman, S.P., 2002, The high water line as a shoreline indicator: Journal of Coastal Research, v. 18, p. $329-337$.

Peltier, W.R., 1997, Postglacial variations in the level of the sea: Implications for climate dynamics and solid-earth geophysics: Reviews of Geophysics, v. 36, p. 603-689.
Pilkey, O.H., and Clayton, T.D., 1989, Summary of beach replenishment experience on U.S. East Coast barrier islands: Journal of Coastal Research, v. 5, no. 1, p. 147-159.

Pilkey, O.H., and Dixon, K.L., 1996, The Corps and the shore: Washington, D.C., Island Press, 272 p.

Psuty, N.P., 1986, Holocene sea level in New Jersey: Physical Geography, v. 7, p. 156-167.

Rast, N., 1984, The Alleghanian orogeny in eastern North America, in Hutton, D.H.W., and Sanderson, D.J., eds., Variscan tectonics of the North Atlantic region: Geological Society of London, p. 197-218.

Rast, N., 1989, The evolution of the Appalachian Orogen, in Bally, A.W., and Palmer, A.R., eds., The geology of North America: An overview: Boulder, Colorado, Geological Society of America, p. 323-348.

Redfield, A.C., 1958, The influence of the continental shelf on tides of the Atlantic coast of the United States: Journal of Marine Research, v. 17, p. 432-448.

Ruggiero, P., Kaminsky, G.M., and Gelfenbaum, G., 2003, Linking proxy-based and datum-based shorelines on a highenergy coastline: Implications for shoreline change analyses: Journal of Coastal Research, Special Issue 38, p. 57-82.

Ruggiero, P., Komar, P.D., McDougal, W.G., and Beach, R.A., 1996, Extreme water levels, wave runup, and coastal erosion, in American Society of Civil Engineers, Proceedings of the 25th International Conference on Coastal Engineering, Orlando, FL, September 2-6, p. 2793-2805.

Ruggiero, P., Komar, P.D., McDougal, W.G., Marra, J.J., and Beach, R.A., 2001, Wave runup, extreme water levels and the erosion of properties backing beaches: Journal of Coastal Research, v. 17, no. 2, p. 407-419.

Ruggiero, P., and List, J., 2009, Improving accuracy and statistical reliability of shoreline position and change rate estimates: Journal of Coastal Research, v. 25, no. 5, p. 1069-1081.

Sallenger, A.H., Krabill, W., Swift, R., Brock, J., List, J., Hansen, M., Holman, R. A., Manizade, S., Sonntag, J., Meredith, A., Morgan, K., Yunkel, J.K., Frederick, E., and Stockdon, H., 2003, Evaluation of airborne scanning lidar for coastal change applications: Journal of Coastal Research, v. 19, p. 125-133.

Schafer, J.P., and Hartshorn, J.H., 1965, The quaternary of New England, in Wright, H.E., and Frey, D.G., eds., The quaternary of the United States: Princeton, N.J., Princeton University Press, p. 113-128.

Shalowitz, A.L., 1964, Shore and sea boundaries: U.S. Department of Commerce Publication 10-1, Washington, D.C., 749 p. 
Stauble, D.K., and Brumbaugh, R.W., 2003, An assessment of the nation's shorelines, USA: Shore and Beach, v. 71, p. 11-18.

Stockdon, H.F., Holman, R.A., Howd, P.A., and Sallenger, A.H., 2006, Empirical parameterization of setup, swash, and runup: Coastal Engineering, v. 53, no. 7, p. 573-588.

Stockdon, H.F., Sallenger, A.H., List, J.H., and Holman, R.A., 2002, Estimation of shoreline position and change from airborne topographic lidar data: Journal of Coastal Research, v. 18 , p. 502-513.

Swift, D.J.P., 1975, Barrier island genesis: Evidence from the central Atlantic shelf, eastern USA: Sedimentary Geology, v. 14 , no. 1, p. 1-43.

Swift, D.J.P., Kofoed, J.W., Saulsbury, P.J., and Sears, P., 1972, Holocene evolution of the shelf surface, central and southern Atlantic shelf of North America, in Swift, D.J.P., Duane, D.B., and Pilkey, O.H.J., eds., Shelf sediment transport: Process and pattern: Stroudsburg, PA, Dowden, Hutchinson and Ross, p. 499-574.

Swift, D.J.P., Niederoda, A.W., Vincent, C.E., and Hopkins, T.S., 1985, Barrier island evolution, middle Atlantic shelf, USA, Part I: Shoreface dynamics: Marine Geology, v. 63, no. 1-4, p. 331-361.

Taylor, J.R., 1997, An introduction to error analysis: The study of uncertainties in physical measurement: Sausalito, CA, University Science Books, 327 p.

Thieler, E.R., and Danforth, W.W., 1994, Historical shoreline mapping (1). Improving techniques and reducing positioning errors: Journal of Coastal Research, v. 10, p. 549-563.

Thieler, E.R., Himmelstoss, E.A., Zichichi, J.L., and Ergul, A., 2009, Digital Shoreline Analysis System (DSAS) version 4.0 - An ArcGIS extension for calculating shoreline change: U.S. Geological Survey Open-File Report 20081278, available at http://woodshole.er.usgs.gov/projectpages/dsas/version4/.
Uchupi, E., Giese, G.S., Aubrey, D.G., and Kim, D.J., 1996, The Late Quaternary construction of Cape Cod, Massachusetts: A reconsideration of the W.M. Davis model: Geological Society of America Special Paper, v. 309, p. 1-69.

U.S. Army Corps of Engineers, 1971, National shoreline study, California Regional Inventory: U.S. Army Engineer Division, South Pacific, San Francisco, CA, 106 p.

U.S. Army Corps of Engineers, 2006, Meterology and wave climate, in Coastal Engineering Manual, Part II, Chapter 2, 72 p., accessed January 21, 2010, at http://140.194.76.129/ publications/eng-manuals/em1110-2-1100/PartII/Part II-Chap_2.pdf.

Valverde, H.R., Trembanis, A.C., and Pilkey, O.H., 1999, Summary of beach nourishment experience on East Coast barrier islands: Journal of Coastal Research, v. 15, no. 4, p. 1100-1118.

van Heteren, S., Fitzgerald, D.M., McKinlay, P.A., and Buynevich, I.V., 1998, Radar facies of paraglacial barrier systems: Coastal New England, U.S.A.: Sedimentology, v. 45 , p. $181-200$.

Walker, H.J., and Coleman, J.M., 1987, Atlantic and Gulf Coast Province, in Graf, W.L., ed., Geomorphic Systems of North America: Boulder, CO, Geological Society of America, p. 51-110.

Weber, K.M., List, J.H., and Morgan, K.M., 2005, An operational mean high water datum for determination of shoreline position from topographic lidar data: U.S. Geological Survey Open-File Report 2005-1027, available at http://pubs.usgs.gov/of/2005/1027/index.html.

Western Carolina University, 2010, Beach nourishment: The U.S. beach nourishment experience including New England, east coast barrier islands, Pacific coast, and Gulf of Mexico shorelines: Western Carolina University, accessed January 21, 2010, at http://www.wcu.edu/1038.asp.

Wright, L.D., 1995, Morphodynamics of Inner Continental Shelves: Boca Raton, FL, CRC Press, 241 p. 
음

3

交

章 